\title{
Results of a statistical evaluation of the Neogene in Hungary
}

\author{
tGéza Hámor \\ Hungarian Geological Institute
}

\begin{abstract}
The present study summarizes the results of formation-statistical investigations for the entire territory of Hungary, complementing the previous partial data in several directions, using methods that have been further developed.

The most important sections of the study deal with

- the basic conceptual and methodological questions of quantitative investigations;

- the vertical evaluation of the Neogene complex;

- the lateral evaluation of the Neogene complex and its facies;

- the presentation of the quantitative investigations according to regional units;

- the designation of the locations of the facies areas, changing through time.

On the basis of the vertical and lateral theoretical sections, the study documents the Hungarian Neogene by means of worm's-eye-facies and paleogeographic map series for six time periods. It is followed by the structural geologic, faciological and stratigraphic conclusions.
\end{abstract}

Key words: facies, paleogeography, stratigraphy, structure evolution, statistic analysis, Neogene, Pannonian Basin

\section{Introduction}

The aim of quantitative investigations is to unify the characterization of lithostratigraphic units and facies areas on the basis of objectively measurable quantitative data, to make changes in structural development, evolutionary history, and facies conditions more exact, as well as to present the event history on facies maps and paleogeographic contour maps following stratigraphic and faciological evaluation by means of summarizing and averaging all of these. The essence of the method is that evaluation is carried out through several

Received: September 20, 2006; accepted: June 6, 2007 
approaches in time and space. The methods check each other and rely specifically on rock composition, deposition, thickness, and horizontal extension basic data. The graphic documentation mainly includes well logs, large geologic sections, worm's-eye-facies maps, and paleogeographic maps, presented as tectonic units correlating with orogenic cycles.

An investigation of the Early Miocene continental formations in the Mecsek Mts (Hámor 1972), and a later statistical investigation and evaluation of the Middle Miocene marine formations and biofacies (Hámor 1975, 1985) can be regarded as antecedents of the methodology. In 1983, Hámor summarized the basic methodological questions and mapping possibilities in a manual. $\mathrm{He}$ published the latter as the Editor-in-Chief of the series of the Neogene paleogeographic maps of Central and Eastern Europe, as well as in the map series on the Neogene paleogeography of the Carpathian Basin and its explanatory notes (Hámor 2001a).

The present study summarizes the results of formation-statistical investigations for the entire territory of Hungary, complementing the previous partial data in several directions, using methods that have been further developed. A direct forerunner of this study is the establishing of the lithostratigraphic system of the Hungarian Neogene; the short description of the formations (in some cases members) can be found in the "Lithostratigraphic Atlas of Hungary".

The most important sections of the study deal with

- the basic conceptual and methodological questions of quantitative investigations;

- the vertical evaluation of the Neogene complex;

- the lateral evaluation of the Neogene complex and its facies;

- the presentation of the quantitative investigations according to regional units;

- the designation of the locations of the facies areas, changing through time.

On the basis of the vertical and lateral theoretical sections, the study documents the Hungarian Neogene by means of worm's-eye-facies and paleogeographic map series for six time periods (6 maps for consecutive periods). The structural geologic, faciological and stratigraphic conclusions are drawn in the closing sections.

\section{Basic conceptual and methodological questions of quantitative investigations}

The aim of quantitative investigations is to characterize rock bodies, and also to represent them in time and space using exact data. The formations and members documented by these simple statistical methods have been evaluated from several points of view, basically within the boundaries of a given facies area or in country-wide summary. 
The first steps in quantitative investigations are the characterization and description of the unique key sections of lithostratigraphic units (members and formations), the collection of numerical data on thickness, bedding, structure, sedimentology and paleontology of the composing rocks, and their layerstatistical evaluation by simple averaging.

The reliability of the characterization of the units can be made more exact by increasing the number of key sections and evaluating their data with the same method, but already including them within the total system. The key sections of the areas, selected later, have already been rendered more complete thanks to the evaluation of other data of the units, such as the rock bodies composing the area; thus the scope of the quantitative investigations is expanded to the field of formation statistics. Its most important elements are average thickness, thickness as a function of the stratigraphic conditions, facies distribution, and changes of all of these in time and space. Formation-statistical investigation of the lithostratigraphic units, both vertically and laterally, is carried out on the basis of the averaged frequency statistics. Even in this case, the formation systems can be investigated within a specific area (geologic region, structural unit, country-wide summary, etc.).

Accordingly, the layer-statistical method predominantly documents and describes the changes in evolutionary and event history, and formation statistics those in structural development, facies alteration, and the paleogeographic picture on the basis of objective data.

\section{Vertical statistical investigations}

The first basic evaluation method of formation statistics for solving the problems of event history, evolutionary history, and stratigraphy (e.g. boundary questions) is the vertical statistical investigation of the formations. These investigations are decisive for a new approach to stratigraphy and structural development (completed with the data of quantitative biostratigraphic and sedimentological features as well as measurable structural elements, according to the specific aim of the interpretation).

The vertical evaluation was based on the data of well logs or outcrop sections. Data on the actual (real) thickness of members, formations, and sedimentary cycles had been previously collected. The thickness data detected in different geologic positions (overlapping or continuous sequences), was calculated separately. Moving toward increasingly larger units, the collection and evaluation of data was expanded to the chronostratigraphic units (orogenic cycles) or facies areas, then to a country-wide summary. All of these data were averaged separately in accordance with the goal of the study and the range of calculation. In every case, averaging was carried out starting from the level of elementary data and repeated in the combined results, in order to avoid the error of averaging the averages. 


\section{Lateral evaluation}

Lateral evaluations (developing later into areal evaluations) serve as a basis for identifying the structural boundaries, reconstructing the facies distribution, the degree of facies transitions (interfingerings), and finally the total paleogeographic picture. The evaluation was carried out on the basis of 48 countrywide large-scale geologic sections, prepared mainly for this study, as well as large-scale geologic sections from some 80 smaller regions extent data, measured in the field within the boundaries which are given on surface geologic maps. Also, in this case, the studied units began as members or formations, and then, following their merging, were linked to certain orogenic cycles and their phases, as well as to the chronostratigraphic units. The calculation methods and evaluation steps of the lateral interpretations are the same as those used vertical evaluations. As a result of the study an exact picture can be formed of the degree of transgression cycles and their connection to orogens, on the basis of the extension of the overlapping deposition or continuous sedimentary area(s). The extent boundaries of the end-of-cycle regressions and structural elements, determining or significantly influencing the facies conditions (possibly buried or sometimes rejuvenating), can be identified.

An important element of the lateral evaluation is the quantitative ecological and biostratigraphic evaluation of the fauna associations related to facies. The solution of the problems of stratigraphic classification and delineation is strongly supported by investigating whether the change in fauna means a true evolutionary change in time (i.e. it can be correlated to global events), or is only the consequence of a lateral facies change. A $20-25 \%$ change in fauna in lateral facies is not rare; however, an age boundary appears with a faunal change of only 5-10\%, in cases of vertical evaluation (Hámor 1964, 1970, 1983, 1985).

Data of basic research value can be obtained for judging the total paleogeographic picture by means of proving the horizontal extent of certain facies belts, complemented by the direction of their thickness changes, the order of magnitude, and the exact designation of the thickness and zone data of the lateral facies transitions. From a tectonic point of view the chronology and magnitude of structural movements (basin formation, hinterland elevation, multiple marginal faults, etc.), connected to certain orogenic cycles can also be definitely demonstrated, or at least their order of occurrence.

A particularly important result of vertical and lateral formation-statistical investigations is the proportion (relative volume) of the facies within a given period of time in the given basin (facies area, certain large basins or the whole country). The presented extensive evaluation and interpretation may be - and should be - the basis of geologic prognoses with different aims, increasing significantly their documenting hinterland, content and means of utilization. 


\section{Basic data of the quantitative investigations of the Hungarian Neogene}

A critical part of the basic data system originates with the Hungarian geologic mapping and shallow structure exploration wells, key geologic wells, and industrial raw material exploration boreholes. The selection of the key wells was a comprehensive task, requiring careful work.

The most important aspect was the selection of boreholes (where possible with cores), penetrating into the substrate and exploring the most complete sequences. During the selection the aim was an even distribution in space and the good resolution of summary maps to be compiled at a scale of 1:500,000. This was achieved by taking into account a proper distance between the wells in the largescale geologic sections mentioned above. Preference was given to the wells in which identification of the formations could be carried out from either cores, ditch cuttings, or well logs of appropriate quality, or laboratory investigations. Beside the sedimentary sequences, wells encountering larger volcanic rock bodies were included in the selection. In addition to the Neogene key well network, a considerable amount of other hinterland material was available, including primarily traditionally documented sequences in some 80 countrywide geologic key sections (at one-meter intervals); furthermore data of individual larger regions (e.g. Transdanubia, the SE Trans-Tisza area, etc.), were assembled on some 30 data sheets. Selected material from the geologic mapping programs, published on maps and in monographs, were widely utilized as well. In the case of the evaluation of certain smaller areas, substitution of missing data for points significant in resolving specific issues was attempted using other borehole information. This occasionally helped in making the section more exact, at least with, for example, data on the deposition depth of the substrate.

It is important to note that sequences were used selectively, chosen from the often very dense borehole network of exploration wells of the industry, and not the entire range. For example, among the nearly 100 boreholes in the Hidas lignite, area only 4-5 representative boreholes were included in the evaluation system. Utilization of the entire body of data was not possible due to its volume, the amount of work this would have involved, and the diversity of the basic documentation. Studies prepared at different time periods, using different methods, at varying depth of detail, by several different authors, contain many uninterpretable, frequently subjective elements. Perhaps this justifies the fact that the quantitative evaluation system is based predominantly on those key wells, reviewed and mostly published personally by the author of this paper and some of his colleagues in the course of the past decades.

Basically, the main concept of grouping the data is to demonstrate the depth of the pre-Neogene basement, as well as the Neogene chronostratigraphic unit of the orogenic cycles, bounded by unconformities (shown more rarely by a paraconformable position within the basin). The country-wide extent and application of the Neogene formation system - and within it specifically the characterization and evaluation of the basal formations of the major sedimentary 
cycles - were decisive aspects. In the revised drilling records, we worked with thickness data of the formations (possibly members), rounded to meters, with no regard to the depth of their position. The measurable, calculable, and editable quantitative layer-statistical data and evaluations are based on these primary data. The formations, not distinguishable in any given borehole, were used in combination with thickness data (e.g. the combined thickness of the Kozárd and Szilágy Formations).

The total number of the boreholes, investigated and at least partly evaluated during the course of this study, is 2,115; this corresponds to 633,511 linear meters (this is not the total length of the boreholes), which provided the abovementioned specific data (see Table 2). The tables reflect well the volume of work involved, the diversity of the Hungarian Neogene, as well as the great number of the facies areas, lithostratigraphic units, and facies (Table 1). Adding up the data in the "Total number of boreholes" columns of the Tables occasionally will result in a greater number, since a single well penetrates several chronostratigraphic, lithostratigraphic or facies units; this is indicated in the summary of several tables.

From the point of view of the evaluation, the relatively even data frequency of the time periods and facies areas, the evaluated linear meters and the number of boreholes, increasing markedly from the beginning of the Neogene as a function of availability, as well as the detailed thickness data of the facies areas of the Neogene and its country-wide average thickness, are favorable factors. The latter is $2,203 \mathrm{~m}$ on average, varying from a couple of meters at the margins to the maximum sediment depth of 7,000 $\mathrm{m}$ in the deep basins.

\section{Results of the vertical statistical evaluation of the Neogene formations}

The vertical evaluation was carried out taking into account the possibilities of comparison with the results of lateral evaluation (see the vertical data sequence in Table 2). The basis of evaluation was the summary of the occurrence frequency in all the studied boreholes for the total Neogene complex. Within this, data of the measured absolute values and percentage of orogenic cycles, including chronostratigraphic units (according to stage and substage) as well as lithostratigraphic units (generally formation, rarely member) were summarized. The evaluation of the formations and of the facies mostly corresponding to them was performed on the basis of the thickness data and the thickness proportion of the individual facies belts. 
Results of a statistical evaluation of the Neogene in Hungary 107

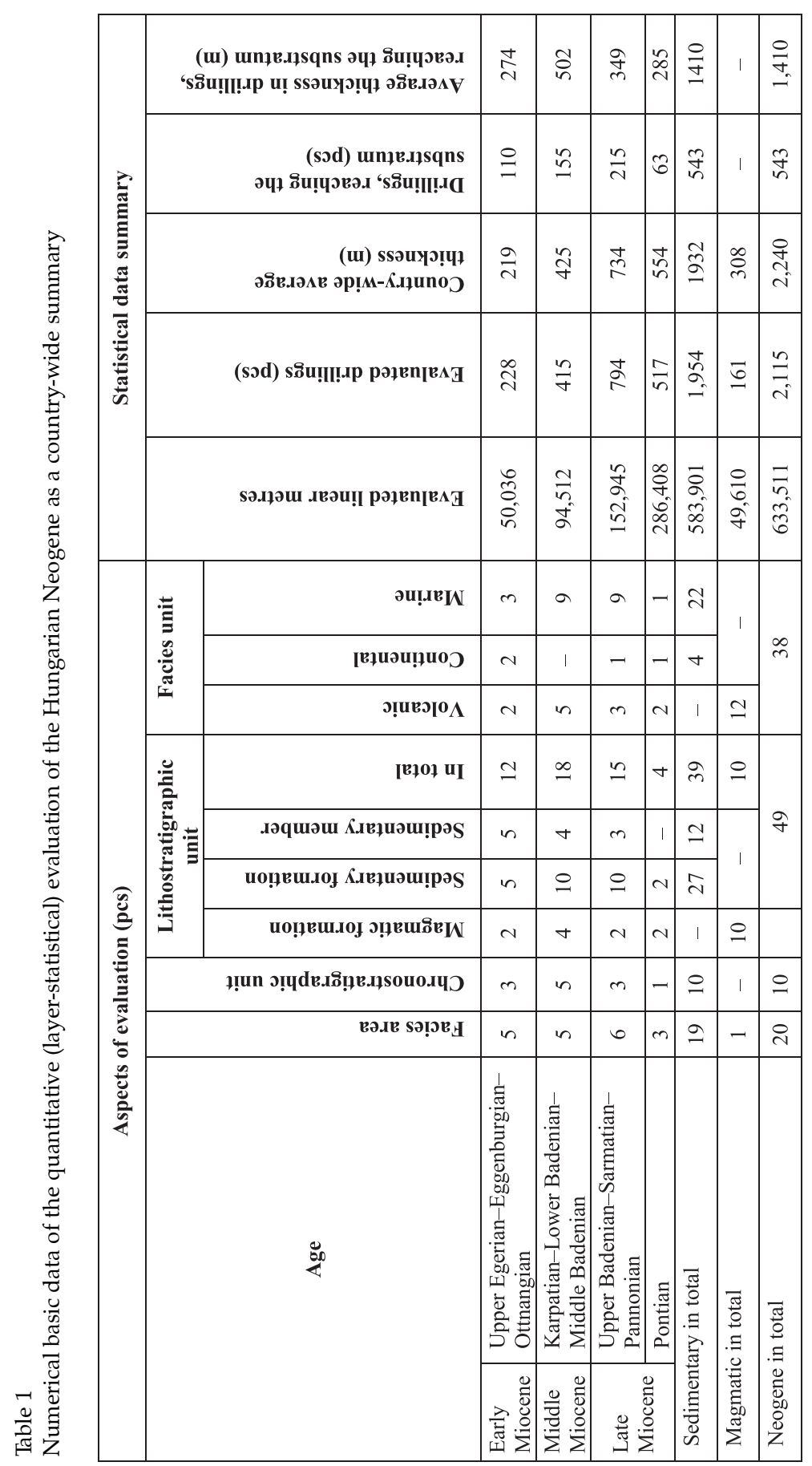

Central European Geology 50, 2007 


\begin{tabular}{|c|c|c|c|c|c|c|c|c|c|c|c|}
\hline \multirow{3}{*}{ 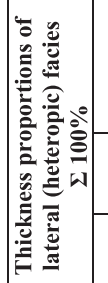 } & \multirow{2}{*}{\multicolumn{3}{|c|}{ 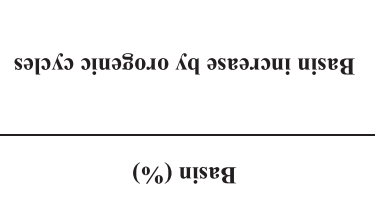 }} & 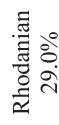 & \multicolumn{3}{|c|}{ 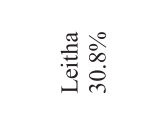 } & \multicolumn{2}{|c|}{ 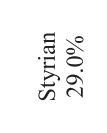 } & \multicolumn{2}{|c|}{ 逽递 } \\
\hline & & & & t & 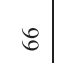 & 6 & t & $\frac{2}{2}$ & $\curvearrowleft$ & $m$ & 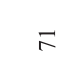 \\
\hline & & deri & & 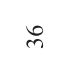 & $\stackrel{t}{m}$ & $\infty$ & 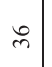 & i & Z & 6 & ते \\
\hline \multirow{2}{*}{ 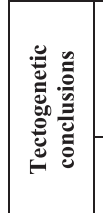 } & \multicolumn{3}{|c|}{ 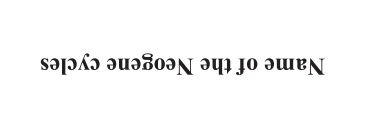 } & 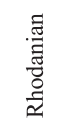 & \multicolumn{3}{|c|}{ 营 } & \multicolumn{2}{|c|}{ 蛋量 } & \multicolumn{2}{|c|}{ 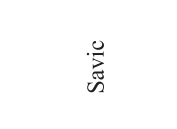 } \\
\hline & \multicolumn{2}{|c|}{ 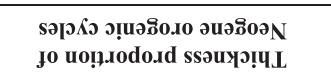 } & $\therefore$ & $\stackrel{\mathscr{m}}{=}$ & \multicolumn{3}{|c|}{ 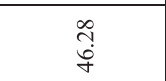 } & \multicolumn{2}{|c|}{$\stackrel{\mathscr{m}}{\underline{g}}$} & \multicolumn{2}{|c|}{$\frac{4}{4}$} \\
\hline \multirow{3}{*}{ 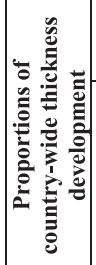 } & \multicolumn{3}{|c|}{ 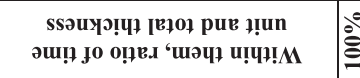 } & $\overrightarrow{\text { ते }}$ & $\stackrel{n}{i}$ & f & $\overrightarrow{+}$ & $\stackrel{?}{?}$ & $\stackrel{\circ}{\stackrel{\mathrm{I}}{ }}$ & $\hat{\infty}_{0}$ & $\stackrel{m}{g}$ \\
\hline & \multirow{2}{*}{\multicolumn{2}{|c|}{ 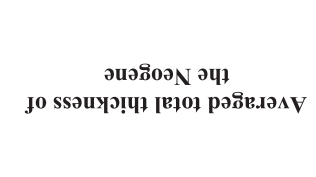 }} & \multirow{2}{*}{ ש } & 埡 & \multicolumn{3}{|c|}{ 㺃焉 } & \multicolumn{2}{|c|}{ 嚑令 } & \multicolumn{2}{|c|}{ 鬳条 } \\
\hline & & & & 急 & 导 & $\stackrel{ \pm}{\circ}$ & \& & $\vec{\Xi}$ & ț & פ & ลิ \\
\hline \multirow{5}{*}{ 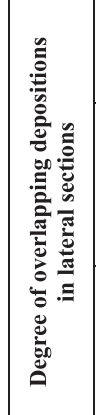 } & \multicolumn{2}{|c|}{ 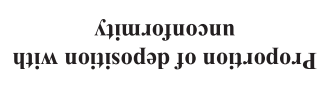 } & $\because$ & $\stackrel{\mathscr{2}}{=}$ & 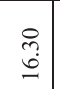 & $\stackrel{\mathscr{\alpha}}{\infty}$ & $\stackrel{\sim}{\sim}$ & $\tilde{z}$ & $\stackrel{5}{s}$ & 总 & $\stackrel{\substack{n \\
i}}{i}$ \\
\hline & \multirow{2}{*}{\multicolumn{2}{|c|}{ 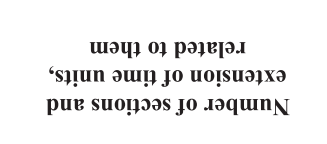 }} & E & $\stackrel{\circ}{\exists}$ & $\underline{n}$ & $\tilde{b}$ & $\stackrel{\text { ปे }}{1}$ & $\frac{\pi}{4}$ & $\tilde{\sigma}$ & $\stackrel{\substack{\infty \\
\infty}}{\stackrel{\infty}{\infty}}$ & 䇣 \\
\hline & & & 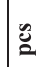 & $\stackrel{4}{4}$ & $\grave{\lambda}$ & $\simeq$ & $\stackrel{\sim}{\sim}$ & $a$ & 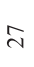 & $i$ & $a$ \\
\hline & \multirow{2}{*}{ 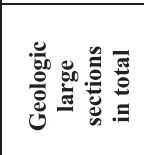 } & $\underline{E}$ & 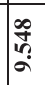 & $\stackrel{\circ}{\rightarrow}$ & \multicolumn{3}{|c|}{ 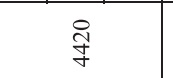 } & \multicolumn{2}{|c|}{ 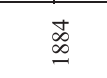 } & \multicolumn{2}{|c|}{$\stackrel{m}{\vec{v}}$} \\
\hline & & $\vdots$ & สิ & बे & \multicolumn{3}{|c|}{ बे } & \multicolumn{2}{|c|}{ ते } & \multicolumn{2}{|c|}{ iे } \\
\hline \multirow{3}{*}{ 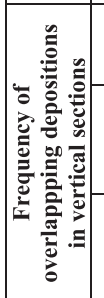 } & \multicolumn{2}{|c|}{ 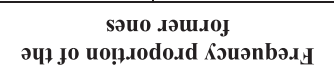 } & $\therefore$ & $\overline{\mathrm{I}}$ & $\stackrel{0}{\infty}$ & 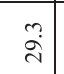 & $\dot{b}$ & $\begin{array}{l}0 \\
\dot{y}\end{array}$ & $\stackrel{\infty}{\sim}$ & 迥 & ¿્స \\
\hline & \multicolumn{2}{|c|}{ 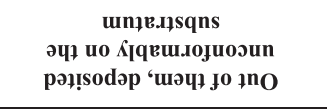 } & 总 & 8 & $\approx$ & F & 尔 & $\stackrel{\infty}{m}$ & $\Xi$ & $\stackrel{\infty}{\infty}$ & $\simeq$ \\
\hline & 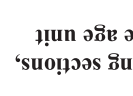 & 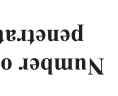 & $\stackrel{g}{\mathscr{B}}$ & i & 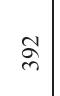 & $\stackrel{\circ}{2}$ & $\tilde{ก}$ & 卓 & i. & $气$ & in \\
\hline & 递 & & 焉 & 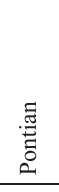 & 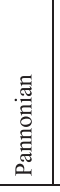 & 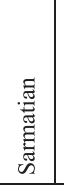 & 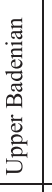 & 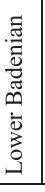 & 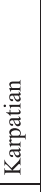 & 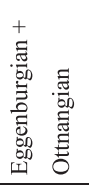 & 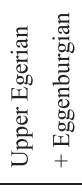 \\
\hline & 气ัّ & & 范 & & 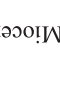 & Iำ & & & או & әиวәо! & 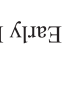 \\
\hline
\end{tabular}


Evaluation of the orogenic cycles on the basis of the thickness data

Based on the Neogene average total thickness values of Table 2, the percentages of orogenic activity, in order of intensity, are:

- Leitha orogenic cycle (with $46.28 \%$ percentage),

- Savic orogenic cycle $(22.12 \%)$,

- Styrian orogenic cycle (12.73\%),

- Rhodanian orogenic cycle $(11.93 \%)$.

The percentage data show the thickness of the orogenic cycle in comparison with $2,240 \mathrm{~m}(100 \%)$ of the averaged Neogene total thickness.

Within the cycles the intensity of certain phases (mostly stage or substage) decreases in volume during the Early Miocene and Middle Miocene (from 13.3\% to $8.9 \%$ during the former and from $12.0 \%$ to $7.3 \%$ during the latter). On the other hand, it is remarkable that the phases of the Leitha orogenic cycle become continuously more intense and - also taking into account the phases of the Rhodanian orogenic cycle - they increase evenly from the $4.1 \%$ percentage of the Upper Badenian to the $25.1 \%$ percentage of the Pontian formations, a more than sixfold increase.

The growth proportion of the thickness of basin formations, related to orogenic cycles, also shows a uniform picture: the thickness of basin formations is almost insignificant during the Savic orogenic cycle (12.6\%); it increases and is already significant during the Styrian orogenic cycle $(29.0 \%)$, and at its greatest during the Leitha orogenic cycle $(30.8 \%)$.

The above data also provide an obvious proof of the previous statement that the Early Miocene deposition developed predominantly in the area of the latest Oligocene residual basins, partly with sedimentation continuity, partly as a product of different facies of the new transgressions. At this time, basin formation was not yet characteristic. The half-graben systems, formed tectogenetically during the Middle Miocene (especially in the neighborhoods of their intersection zones), can already be regarded as the beginning of more marked basin formation. The events of classic basin formation can only be clearly connected to the Late Miocene, taking into account the structural features, the expansion and the mobility of the basement.

Evaluation of the orogenic cycles on the basis of stratigraphic conditions, facies proportion and sedimentation rate

The predominantly Late Miocene expansion and basin formation are also confirmed by the overlapping, discordant position of the basal formations of the Leitha orogenic cycle. This means $50.7 \%$ of the length of the horizontal extension, measured on the edited large-scale geologic sections, and $27.58 \%$ of all studied boreholes. The difference between the two values is explained by the fact that the boreholes are data points and represent absolute values, while the edited sections 
also show the surface or near-surface onlapping depositions. Obviously one must not forget that the edited sections contain more conceptual elements. This interpretation is also supported by the data of the Upper Badenian series, obtained from the Leitha orogenic cycle. Of the total extent length of the cycle, the Upper Badenian basal formations predominate with a $50.9 \%$ percentage, while $23.15 \%$ of all the studied boreholes show overlapping of the substrate. However, a reliable correlation of the borehole data and the published data is proved by the fact that the Leitha orogenic cycle consists of $36.0 \%$ of the Neogene country-wide average total thickness according to the lateral evaluation, and shows a similar proportion (33.3\%) according to the vertical evaluation as well.

Data of the vertical evaluation are shown in Tables 2 and 3, as well as Fig. 1. The text figure contains thickness and age data of the Neogene formations (rarely members), deposited above the Paleozoic-Mesozoic substrate, together with the age boundaries, determined on the basis of $\mathrm{K} / \mathrm{Ar}$ absolute age values, the duration of sedimentation, and the calculated values of the sedimentation rate. The figure illustrates schematically the facies conditions, the situation of the marginal and basin formations within the given tectonic unit, and their characteristic vertical thickness data.

\section{Results of the lateral formation-statistical investigations of the Neogene}

The results, documented in the form of a model and in all cases built on quantitative data, are shown in country-wide overview in Fig. 2.

The aim of the lateral formation-statistical investigations is to characterize the lateral changes in the formations (rarely members) occurring in the geologic structure, to measure their extent, prove the horizontal facies transitions (interfingerings) and determine their zones, as well as document the changes of all these in time. The final goal is to compile facies sections, worm's-eye-facies maps (overlapping or deposited on the substrate) and interpret them in paleogeographic maps.

The method of the lateral formation-statistical investigations is to designate the first Neogene development, member or formation deposited on the substrate, and its linear or multidirectional extent in the geologic maps, the edited large-scale geologic sections and the areas outside them, during the evaluation of the individual key wells. In this evaluation the data of a younger lithostratigraphic unit deposited unconformably on the Paleogene or Neogene, older than the studied formations, are of equal importance when they appear with a demonstrable stratigraphic or sedimentary hiatus of at least stage order, or significant facies deviation.

The formation extenst, measured in large-scale geologic sections and corresponding to the above aspects, was correlated between the individual

Fig. $1 \rightarrow$

Results of vertical/quantitative (layer-statistical) investigations of the Neogene in Hungary (structural development, evolutionary history, stratigraphy; after the chronostratigraphic scale of Gradstein and Ogg 2004) 


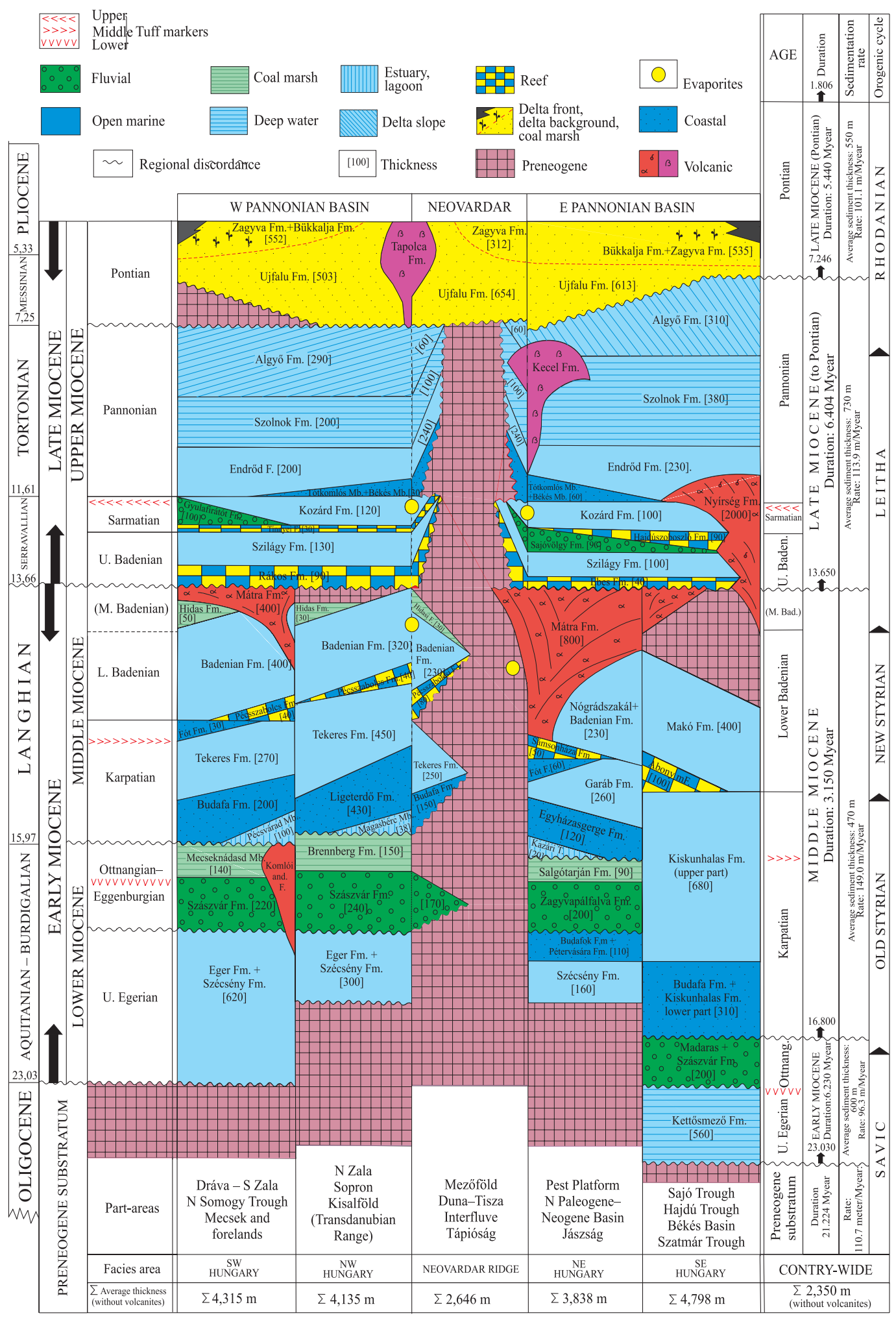




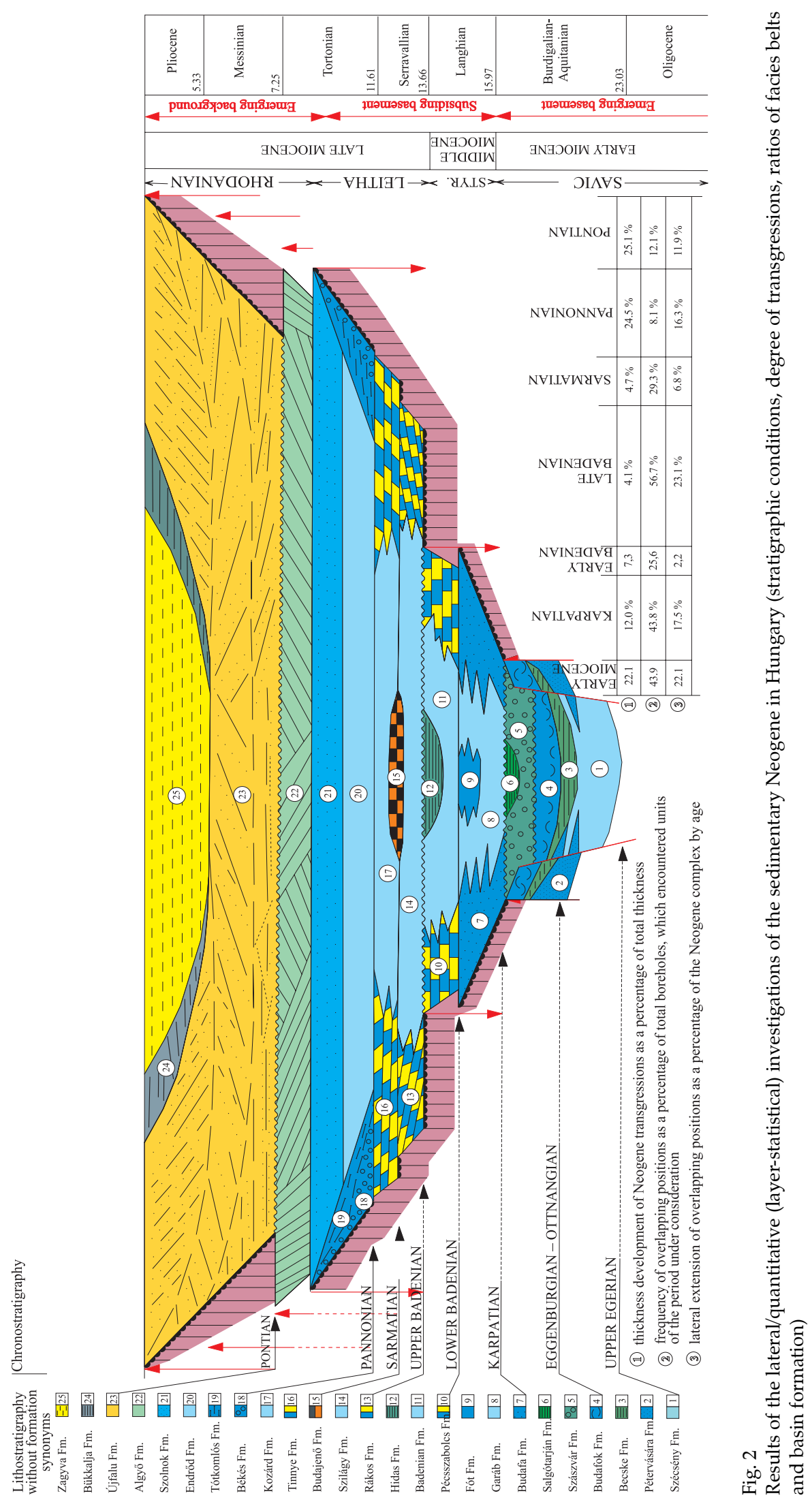


Results of a statistical evaluation of the Neogene in Hungary

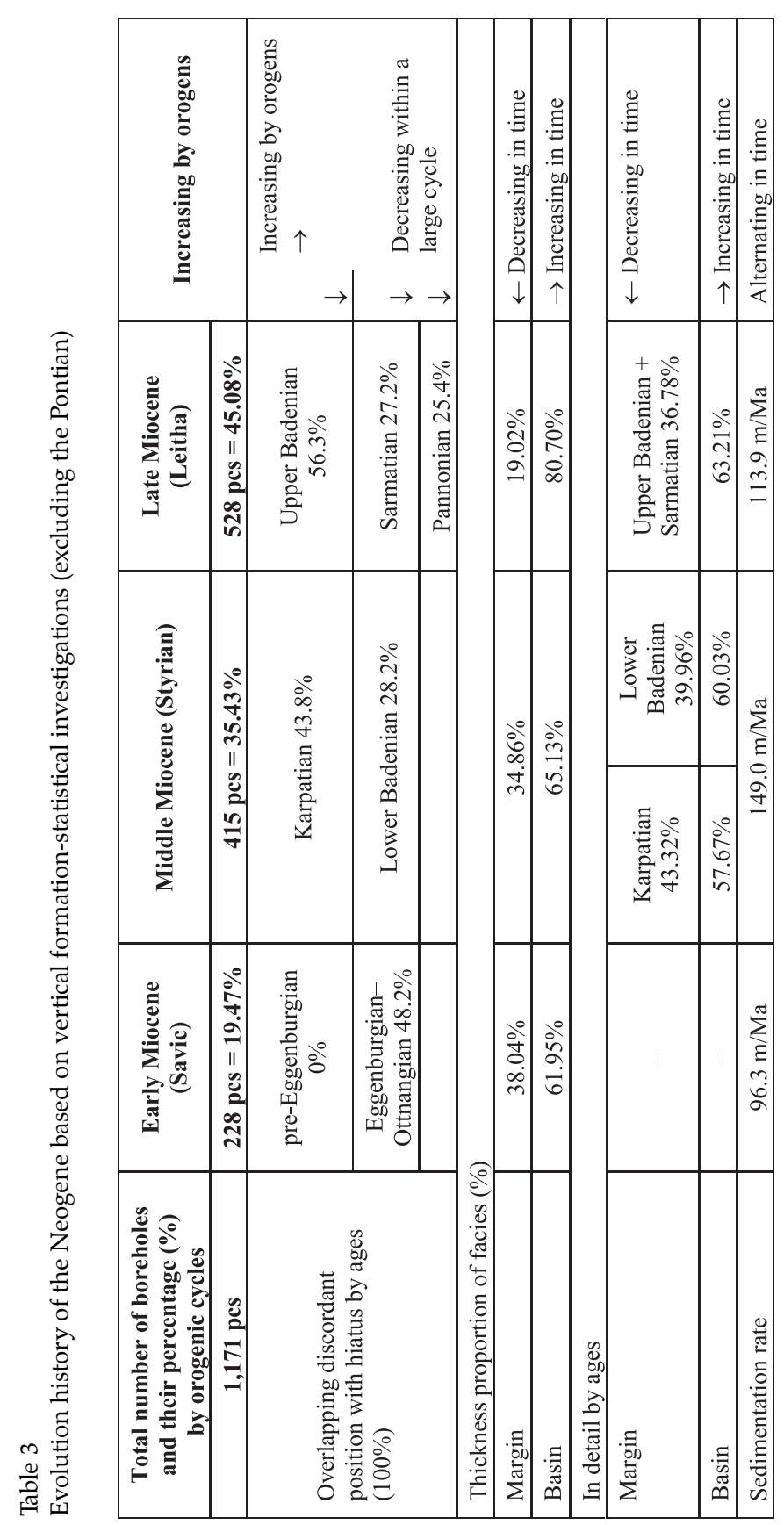

Central European Geology 50, 2007 
sections. The measured numerical data were converted into $\mathrm{m} / \mathrm{km}$ units in accordance with the scale of the section or the worm's-eye-facies map to be compiled.

Data of the lateral evaluation of the given facies area or country-wide summary were recorded for compiling the extrapolated paleogeographic map as follows: i) percentages (this shows that the given formation or facies was developed in specific percentages of all the evaluated section length or area); ii) extent in $\mathrm{km}$ and the number of occurrences of the formation or facies; iii) the ratio of the latter two data gives a statistically characteristic value of the average width of the lateral facies belts of the studied area.

The data, summarized in the tables, can be viewed according to age and formations in the country-wide overview in Table 4, and according to orogenic cycle, stratigraphic condition, proportion and lateral width of facies in Table 5. These data are the measured values of $8,879 \mathrm{~km}$ pre-Pontian $+1130 \mathrm{~km}$ Pontian $=10,009 \mathrm{~km}$ total section length.

\section{Comparative study of vertical and lateral formation-statistical evaluations}

Data in Tables 3 and 4 were complemented with further stratigraphic, structural geologic, sedimentary geologic and faciological evaluations from the data of the country-wide summary. The investigation of the sequence was extended to the Pontian formations as well. Based on the already existing country-wide collection and percentage calculation of the elementary data, repeated investigations were carried out, as mentioned in the methodological preface. Their results are presented in Table 5 in chronological order, according to the frequency and degree of overlapping deposition as well as the degree and proportions of the country-wide thickness developments. The tectogenetic conclusions are supported by the presentation of the thickness data of the sediments of the Neogene orogenic cycles, mass proportions of the orogenic cycles. The facies connections (and their tectogenetic hinterland) are shown by the proportions of the marginal and basin facies by age. The steady increase of the Pannonian Basin and its antecedents from the beginning of the Styrian cycle - which turned out to be consistently around 30\% during the Styrian, Leitha and Rhodanian cycles - is remarkable. Within it, varying marginal-basin facies ratios can be detected in the Styrian cycle, while in the Leitha and Rhodanian orogenic cycles the definitively-developed Pannonian Basin is characterized by the 1:2 ratio of the marginal and basinal facies, in favor of the latter.

Summarizing the results of Tables $3,4,5$, it can be stated that:

1) The proportions of the orogenic cycles in space increase equally in terms of the total number of boreholes and the length of all the investigated large-scale geologic sections in the vertical evaluation, from a proportion of $19-23 \%$ in the Early Miocene through $25-35 \%$ in the Middle Miocene to $45-50 \%$ in Late Miocene (excluding the Pontian). 


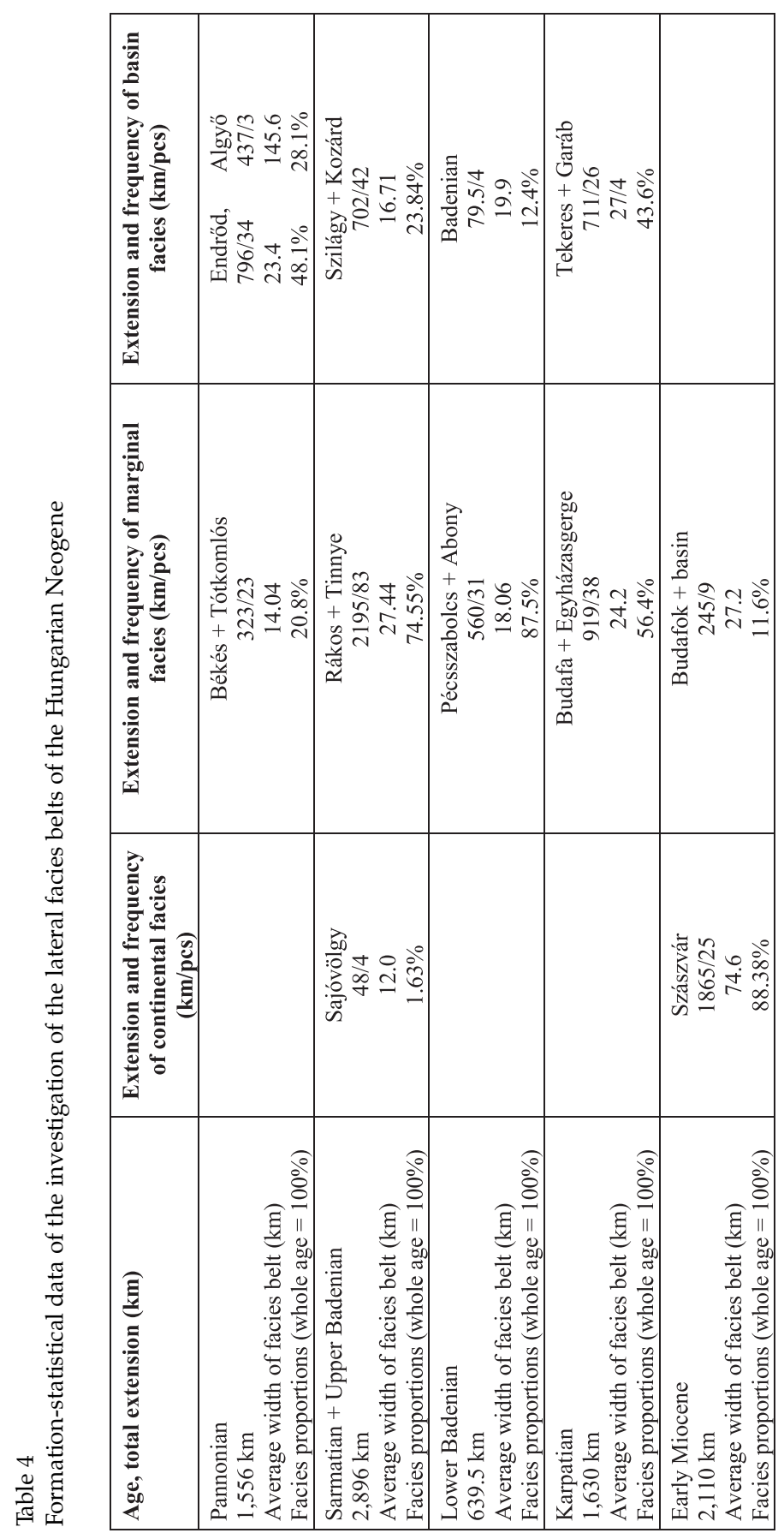

Central European Geology 50, 2007 
Table 5

Results of the lateral formation-statistical investigation of the Hungarian Neogene according to orogenic cycles, with correlation between stratigraphic conditions and facies mass proportions

\begin{tabular}{|c|c|c|c|c|}
\hline $\begin{array}{l}\text { Total length of the studied } \\
\text { sections }(\mathrm{km}) \text { and their } \\
\text { extension percentage }(\%) \\
\text { by orogenic cycles }\end{array}$ & $\begin{array}{l}\text { Early Miocene } \\
\text { (Savic) }\end{array}$ & $\begin{array}{l}\text { Middle Miocene } \\
\text { (Styrian) }\end{array}$ & $\begin{array}{l}\text { Late Miocene } \\
\text { (Leitha) }\end{array}$ & $\begin{array}{c}\text { Tendency of } \\
\text { change }\end{array}$ \\
\hline $8,879 \mathrm{~km}=100 \%$ & $2,110 \mathrm{~km}=23.8 \%$ & $2,269 \mathrm{~km}=25.6 \%$ & $4,500 \mathrm{~km}=50.7 \%$ & Increasing \\
\hline $\begin{array}{l}\text { Discordant position with } \\
\text { hiatus by ages }(100 \%)\end{array}$ & $\begin{array}{c}\text { pre-Eggenburgian } \\
11.6 \% \\
\text { Eggenburgian- } \\
\text { Ottnangian } \\
88.4 \%\end{array}$ & $\begin{array}{c}\text { Karpatian } \\
70.8 \% \\
\text { Lower Badenian } \\
28.2 \%\end{array}$ & $\begin{array}{c}\text { Upper Badenian } \\
50.9 \% \\
\text { Sarmatian } \\
14.5 \% \\
\text { Pannonian } \\
34.6 \% \\
\end{array}$ & Alternating \\
\hline $\begin{array}{l}\text { Facies proportions by ages } \\
(100 \%) \\
\text { Marginal facies } \\
\text { Basin facies }\end{array}$ & $\begin{array}{l}88.4 \% \\
11.6 \% \\
\end{array}$ & $\begin{array}{l}65.2 \% \\
34.8 \% \\
\end{array}$ & $\begin{array}{l}55.6 \% \\
43.0 \% \\
\end{array}$ & $\begin{array}{l}\text { Decreasing } \\
\text { Increasing }\end{array}$ \\
\hline $\begin{array}{l}\text { Width of facies belts by } \\
\text { orogenic cycles }(\mathrm{km}) \\
\text { Marginal facies } \\
\text { Basin facies }\end{array}$ & $\begin{array}{l}74.60 \mathrm{~km} \\
27.22 \mathrm{~km}\end{array}$ & $\begin{array}{l}21.12 \mathrm{~km} \\
23.60 \mathrm{~km}\end{array}$ & $\begin{array}{l}20.74 \mathrm{~km} \\
61.90 \mathrm{~km}\end{array}$ & $\begin{array}{l}\text { Decreasing } \\
\text { Alternating }\end{array}$ \\
\hline
\end{tabular}

2) During the same periods, in the lateral evaluation the overlapping discordant position decreases with peak values of 88\% (EggenburgianOttnangian), 71\% (Karpatian), 51\% (Upper Badenian) - within their own chronostratigraphic tectonic units. However, the decrease can be clearly detected with proportions of $12 \%-44 \%-56 \%$ in the vertical evaluation. As compared to the above, it is an anomaly that $35 \%$ can be shown as a ratio of the discordant overlapping position according to the lateral evaluation, and only $25 \%$ according to the vertical evaluation during the Pannonian.

3) The regressive flank of the orogenic cycles is well outlined in the values of $12 \%$ of pre-Eggenburgian/Early Miocene, $28 \%$ of Lower Badenian and $14 \%$ of Sarmatian.

4) The process of basin formation is well reflected in the alternation of facies conditions. The orogenic cycles, becoming younger, are characterized by the change in the proportion of marginal and basinal facies, independently of the fact whether the vertical or the lateral evaluation method is used. The ratios of marginal facies are $38 \%-35 \%-19 \%$ in the three Neogene orogenic cycles in vertical evaluation. During the same period, this is reflected by the series of ratios of $88 \%-65 \%-56 \%$ of lateral evaluation.

The ratios of basinal facies change in the opposite direction: according to the vertical evaluation in a proportion of $62 \%-65 \%-81 \%$, while in the lateral evaluation their frequency and quantity increase in a proportion of $12 \%-35 \%-43 \%$.

5) The lateral extent of the facies belts (facies zones) - without taking into account the interfingering facies zones - can be documented with certainty only 
by the degree of the horizontal extent along the key sections: the width of the marginal facies belt during the three orogenic cycles decreases or remains steady $(75 \mathrm{~km}-21 \mathrm{~km}-21 \mathrm{~km})$; at the same time the average zone width of the basinal facies increases $(24 \mathrm{~km}-27 \mathrm{~km}-62 \mathrm{~km})$.

6) Similar well-correlating data are provided in terms of the facies proportions and width of facies belts by the investigations, with the two parallel approaches by age (stages or substages).

7) A very important result is that the investigations, described under items 5.45.6, present definite proof of coeval heteropic facies (formations or members), their stratigraphic evaluations and classification and at best their interfingering in space and time. Data of the transitional (interfingering) facies belts are shown in the remaining tables.

\section{Regional results of the formation-statistical investigation of the Hungarian Neogene}

A final goal of formation-statistical investigations is the regional evaluation of results (Table 6).

1) Within it, the order of the tasks is as follows:

- a primary task is characterizing by quantitative approach and proving facies connections of the lithostratigraphic basic units (formations, members, beds) of stratigraphy;

- based on them, determining exactly the geodynamic events (sedimentary and igneous geologic cycles) of the orogenic cycles in the time-space system;

- demonstrating the structural units, also within the given time unit. This occurs partly in an inductive way by improving the precision of the structural model and of the boundary faults of the pre-Neogene substrate (e.g. proving transgression echelons, carrying out the paleogeographic-morphogenetic investigation of thrusting structures), and partly in a deductive way by presenting the synorogenic structural elements (e.g. linear elements of paleogeographic boundaries and lateral facies interfingerings, repeated in several cycles above mobile zones, and magmatic activity);

- as a final result of all of the above, facies areas can be designated and their boundaries determined. The main aspects of their evaluation are to prove the decisive differences between the greater time units; and within the time unit, to demonstrate the similarities and differences normally characteristic of areas of different development.

2) Regional evaluation is suitable for various applications: it may place the compilation of geologic, structural geologic, and of applied geologic maps on an increasingly objective basis. The quantitative data of the paleogeographic and facies maps may definitely contribute to raising the documenting value of manifold thematic prognoses to a higher level. This especially holds true for the possibilities of the exact compilation of worm's-eye-facies maps, as well as the 


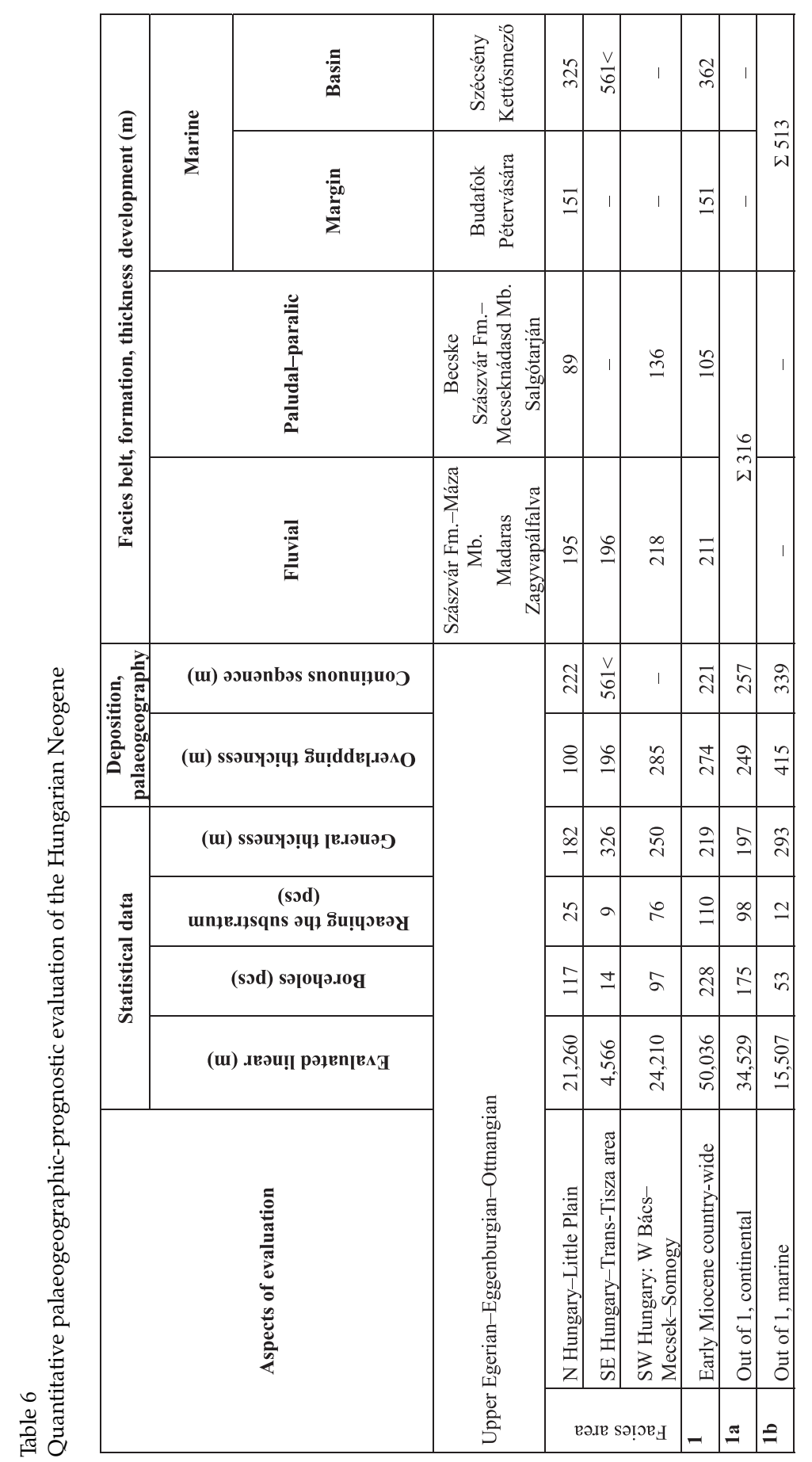

Central European Geology 50, 2007 


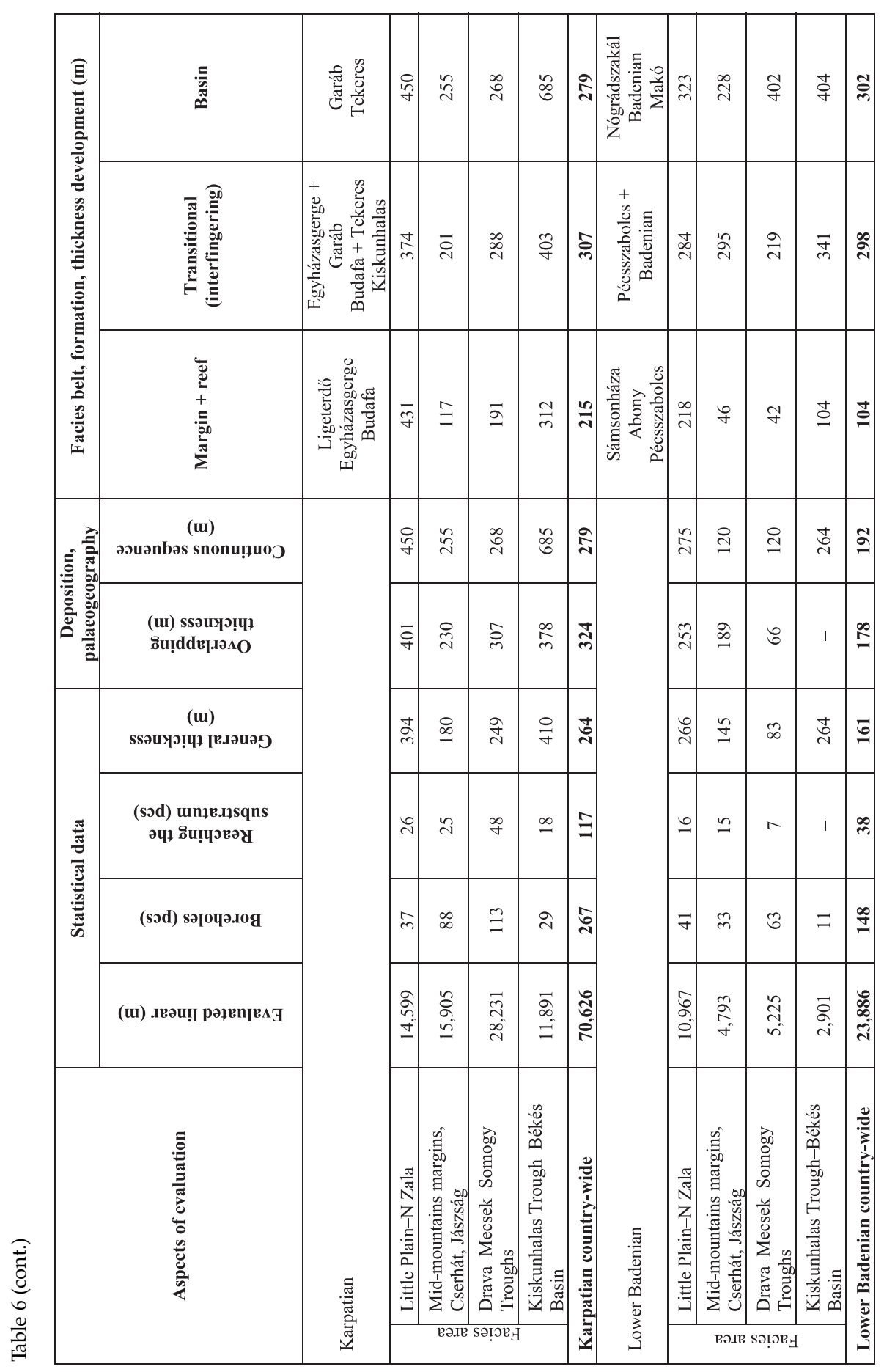

Central European Geology 50, 2007 


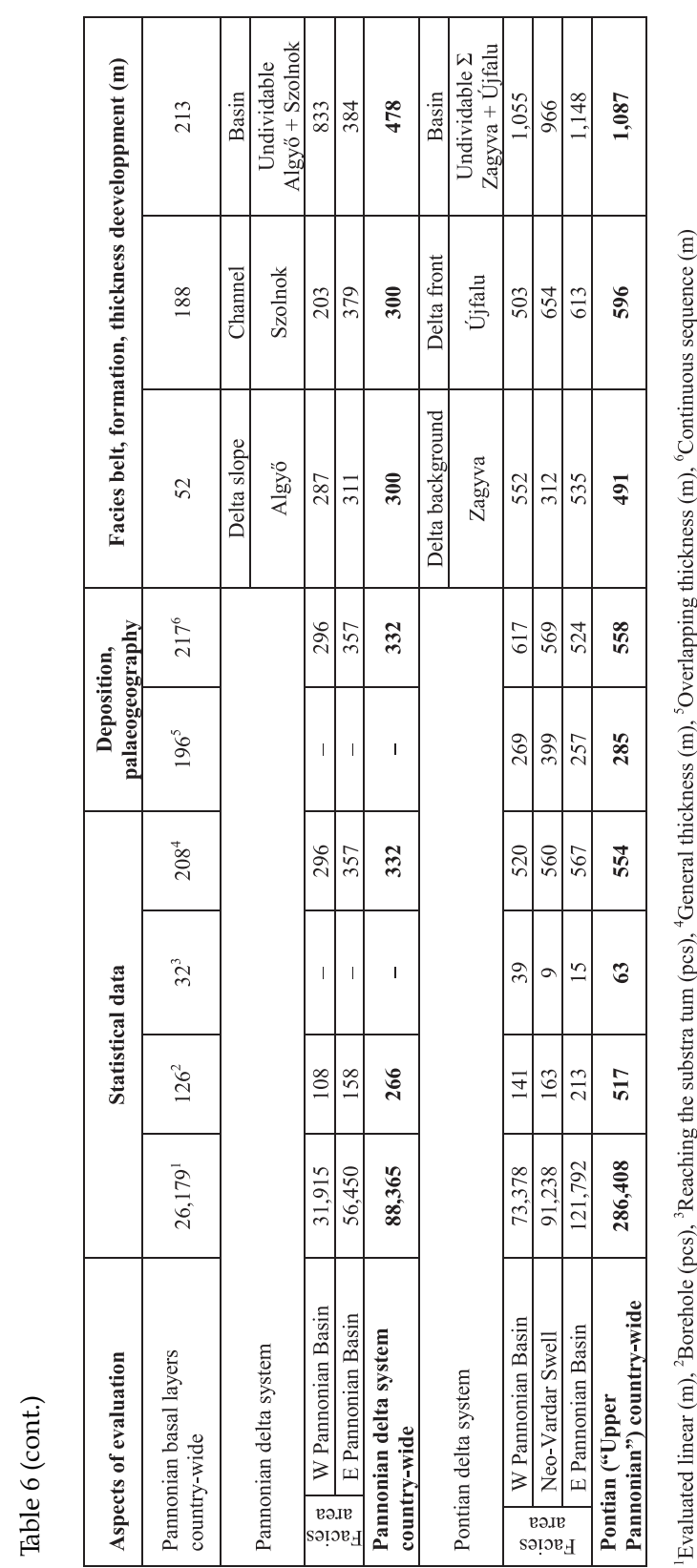

accumulation of raw materials and the discovery of geologic hazard sources, etc.

Last but not least, regional evaluation, carried out in expanding circles, is of basic research value and may enrich our geologic knowledge with data and correlations over increasingly areas in the field of stratigraphy, sedimentary geology, etc.

3) The results of regional evaluation are summarized in Table 6 and in Fig. 1. The items of evaluation were as follows: age (up to order of stages, in some cases substages, finally main stages, then in units of orogenic cycles), facies areas, and then country-wide summary. Data frequency (linear meters of boreholes, number of boreholes, the number thereof reaching the substrate), thickness data (total general thickness, general thickness in overlapping or continuous sequences), and formation and facies belt sizes (thickness development in $\mathrm{m})$, were taken into consideration

Early Miocene (Upper

Egerian-Eggenburgian-Ottnangian)

In this period, three main facies areas can be distinguished in the area of Hungary: Little Plain-Northern Hungary, SE Hungary (Trans-Tisza area), and SW Hungary (Transdanubia) (Fig. 3, Table 6, first part). 


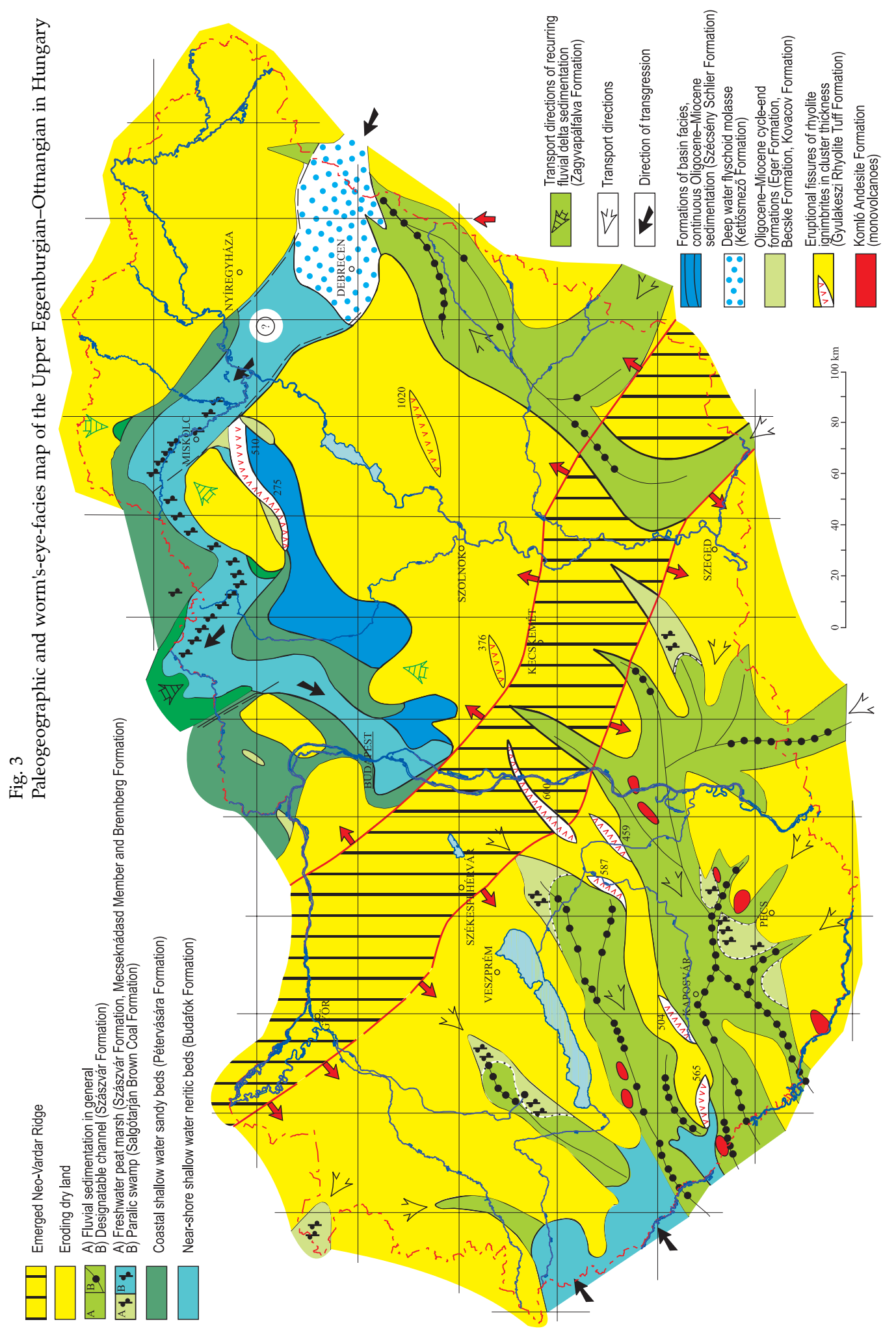




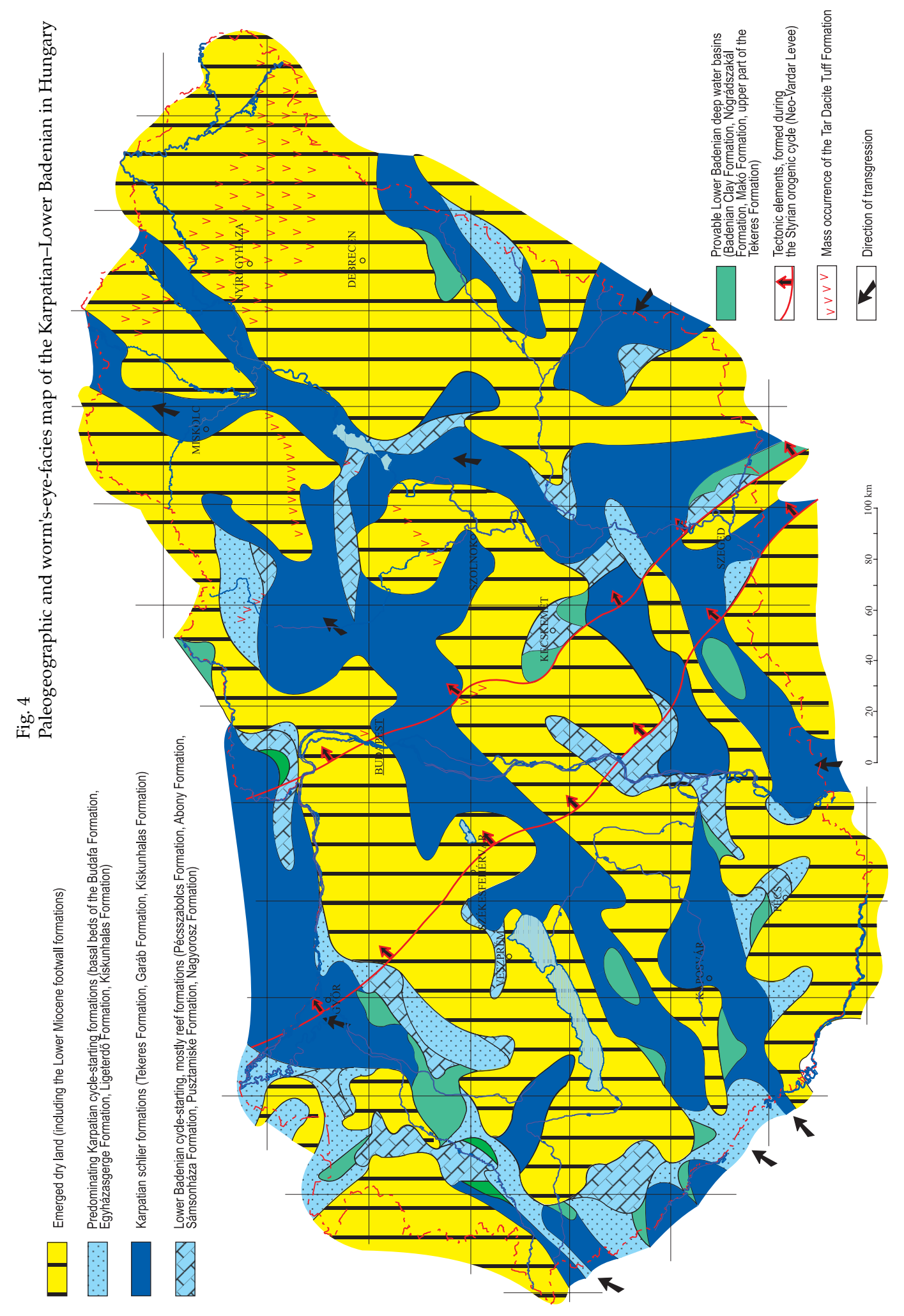


On the basis of the data in the tables, at this time the SW Hungarian facies area was the most mobile. Sixty-nine percent of the studied boreholes reached the substrate, and practically $100 \%$ of the complexes are of continental facies; in average thickness of Early Miocene in overlapping position the greatest $(285 \mathrm{~m})$ is located here. In the SE Hungary facies area (Trans-Tisza area and within it predominantly the neighborhood of the Sajo Trough), only $8.2 \%$ of the studied boreholes reached the substrate or Neogene formations deposited over it. The sequence is composed of $26 \%$ continental formations and of $74 \%$ marine ones. In the "Continuous sedimentation" column, the flyschoid-molasse series of the Kettősmezô Formation is stands out with an average thickness, which probably exceeds $560 \mathrm{~m}$. The third facies area does not show prominent values; its dynamics and facies conditions are balanced.

Based on this short summary and the other data of the table, it can be stated that in the SW Hungarian facies area east of the Neo-Vardar Ridge, hinterland elevation prevailed during the given period. In the continental environment, transportation of coarse debris, the thickness of which increases westward, occurred partly from the Neo-Vardar Zone, partly from the Alpine-Dinaric margin.

On the flanks of the fluvial basins, the flood plain-paludal facies becomes prevailing; thus the thickness of continental series decreases almost by half. The marine basin (base level) was situated in the territory of the Drava-Sava Depression, extending partly to the North Zala area. To sum all this up, the approximately W-E-vergent zone encountered in the southern third of Hungary and situated above the contact zones of the tectonic subunits of the Tisza Megaunit, was the most mobile.

It is remarkable that the axis of the basin east of the Neo-Vardar Ridge dips eastward, just like during the Oligocene. The initial updoming of the Neo-Vardar Ridge causes the delimitation of western and eastern areas. Thus, the survival of the Paleogene flysch basin at the beginning of the Early Miocene, the advance of the new (Eggenburgian) transgression from the Transylvanian Basin northwestward, as well as the only minimal continental debris transport from the eastern margin of the Neo-Vardar Ridge, are normal in the latter area.

\section{Middle Miocene (Karpatian-Lower Badenian)}

In order to present the old Styrian and new Styrian phases of the Styrian orogenic cycle, the results of the layer-statistical investigation of the Karpatian and Lower Badenian ages are discussed separately. Due to structure formation, by this time four facies areas had already come into being in approximately WSW-ENE-vergent trough systems from $\mathrm{N}$ to S: North Zala-Little Plain, the margins of the Hungarian Range-Cserhát-Jászság, the Drava-Mecsek-Somogy Trough, and the Kiskunhalas Trough-Békés Basin (Fig. 4, Table 6). 


\section{Karpatian stage}

On the basis of the tabulated data the Drava-Mecsek-Somogy Trough is the most mobile structure among the facies areas following the contact line of the Mid-Transdanubian and Mecsek tectonic units (Mid-Hungarian Lineament and synonyms). Forty-one percent of the studied boreholes encountered Neogene series deposited on the substrate. Practically $100 \%$ of total thickness was formed in marine facies, with a slight fluvio-deltaic interlude in the Western Mecsek Mts and at the boundary of the Eastern Mecsek Mts (Keresztúr Formation). Twentysix percent of the total Karpatian thickness is of marginal and 36\% of basinal facies; thus the facies proportions are balanced. Consequently, the thickness of the interfingering facies (transitional development) amounts to $38 \%$.

A similar mobility is also shown in the North Zala-Little Plain area. Twenty-two percent of all the boreholes reaching the substrate in Hungary can be found in this zone. Here also $100 \%$ of total thickness is of marine facies; fluvio-deltaic facies is known only in small extent in the surroundings of Sopron (lower part of the Ligeterdô Formation). The thickness of the facies belts is balanced: the marginal facies has $34 \%$, the basinal facies $36 \%$, and the transitional facies $30 \%$ proportion in the total Karpatian thickness of the facies area. It should be mentioned that thickness data of the Karpatian series show prominent values in the zone of the Kiskunhalas Trough-Békés Basin as well. In Hungary the greatest average thickness $(410 \mathrm{~m})$, the greatest average thickness in the case of a continuous sediment sequence $(685 \mathrm{~m})$, and the thickest schlier development (exceeding $1,000 \mathrm{~m}$ as a unique value) can be found here.

\section{Lower Badenian substage}

During this period the North Zala-Little Plain facies area is the most mobile due to the new Styrian orogenic phase. The structure roughly follows the structural boundary line of the Alpine and Transdanubian Range tectonic units (Rába Line). The basin is divided into two almost symmetrical parts, statistically differing from each other only in smaller details, caused by the initiation of the NE-SW-vergent Mihályi Ridge. Early or Middle Miocene formations are not found on the ridge, either due to original paleogeographic reasons or later erosion. The ridge later preserves its mobility with alternating intensity. In the whole of the territory, $42 \%$ of the studied boreholes encountered exclusively marine Lower Badenian formations. The average thickness of the series, deposited on the substrate in an overlapping, discordant way, is $266 \mathrm{~m}$. Twentysix percent of total thickness is made up of marginal facies (Pécsszabolcs Formation, "Lower Leitha Limestone"), and 39\% of basinal facies (Badenian Clay Formation). The interfingering series of the vertical facies transition amounts to a percentage of $34 \%$. The data show extraordinary similarity to the second most mobile structural unit of the Karpatian, the Drava-Mecsek-Somogy Trough. 
In the evaluation of the latter, the number and facies of the boreholes, which proved overlapping, correspond to the Karpatian data of the North Zala-Little Plain (the facies is $100 \%$ marine, the percentage of boreholes reaching the substrate is $19 \%$, the thickness of the zone of the vertically interfingering facies is also $33 \%$, which means a correspondence within limit of error). However, the proportions of facies developments show great differences: the percentage of series of marginal facies is only $6 \%$, while that of basinal facies is $60 \%$, that is ten times higher. This can be explained by the fact that, although the greatest thickness of the Lower Badenian basin formations in Hungary can be found in the Csapod Trough (the Badenian Clay Formation is around 1,000 m thick and may possibly also contain the transition of the Tekeres and Badenian Formations), and that the general thickness is also the greatest here $(266 \mathrm{~m})$, the sub-basins of these formations have a greater extent in the area of the Drava-Mecsek-Somogy Trough. They include, for example, the smaller basins of the Drava Valley, the surroundings of Inke, the Western Mecsek Foreland, containing several hundred meter-thick Lower Badenian formations. At these locations, however, the average thickness reaches only $83 \mathrm{~m}$, due to the proximity of the elevated inselberg structures.

Summary of the evolutionary and paleogeographic events of the Early and Middle Miocene

The vertical and lateral results of the layer-statistical investigation of the Early and Middle Miocene are presented separately from the younger event history. This is due to the fact that the antecedents of the formation of the Pannonian Basin occurred during different orogenic cycles, under differing structural conditions and paleogeographic situations.

The age of the Early Miocene is presented in the worm's-eye and paleogeographic maps in Fig. 3. At this time, a NW-SE-vergent axis (Neo-Vardar Ridge) divided the area of the country into two parts. Its southwestern and northeastern flanks show a bilateral symmetry in terms of the geodynamic events and sedimentary processes. In both areas, foreland continental sediments and marine series, laterally connected to them, are characteristic in the proximity of the elevated ridge.

The ratio of the continental and marine sediments is almost $100 \%$ in the western area in favor of the former. Here, the direction of sediment transport was to the SW. The transgression came from the SW (from the Atlantic-Mediterranean region) and advanced approximately to the Drava Line in present-day Hungarian territory. Thus, marine sediments can be found in the southwestern part of the country (for instance in the Kerka Valley, in the surroundings of Budafa-Lovászi), in some boreholes even in considerable thickness.

In the eastern area the thickness of the marine facies increases to three times that of the continental sediments in a southeasterly direction (in the continuation 
of the Sajó Trough), in the flyschoid-molasse basin formed there. The transgression is NW-vergent; the continental sediments were deposited in SEvergent transport channels (Kettősmező Formation as well as Madaras Formation).

At the beginning of the Middle Miocene, the axis direction of the predominant basins changes to NE-SW, with a southwesterly dip. The new transgressions came from the SW (the Mediterranean Basin - see the worm's-eye-facies and paleogeographic maps in Figs 4 and 5). Northeastward, longitudinal troughs run through the entire Carpathian Basin. Their structural formation in two phases belonging to the Styrian cycle, occasionally also overprints also the transversal Neo-Vardar structure in some places (e.g. Kunság Trough, Kiskunhalas Trough). In the western parts of the country a smaller volume of continental material transport, originating from the Sopron and Mecsek Mts and their hinterlands to the SW, can be detected at a later stage. Their extent is local and their thickness not statistically significant. The transgressions, renewed during the Karpatian and Lower Badenian, thin out mostly only at the western marginal zones of the Carpathians. In Hungarian territory, the average total thickness of the Middle Miocene is $645 \mathrm{~m}$ in the west and $539 \mathrm{~m}$ in the east. Thus, the decrease toward the $\mathrm{NE}$ is about $10 \%$. In the Carpathian forelands, at the end of the troughs, restricting evaporitic (salty) end lagoons frequently came into being.

During the Karpatian, among the Hungarian facies areas the southern basin system proved to be more mobile (Drava-Mecsek-Somogy Trough, including the system of Kiskunhalas Trough-Békés Basin-Derecske Trough). This picture was supported by the separate layer-statistical investigation of the Karpatian marginal formations: in the northern basin trench (form North Zala to Jászság), the thickness of the marginal facies is $170 \mathrm{~m}$ in the $\mathrm{W}$ and $165 \mathrm{~m}$ in the $\mathrm{E}$ in average, that is practically equal. The same thickness in the southern basin trench (in the Drava Valley-E Békés line) is $249 \mathrm{~m}$ and $246 \mathrm{~m}$, respectively, with spectacularly concordant data.

The new Styrian orogenic phase, preceding the Lower Badenian, created a reverse situation: the main direction and zone of marine transgression shifted northward. At this time, the Zala-Little Plain-Cserhát-Jászság trough system was more active, though the paleogeographic framework practically did not change. Here, different rates of vertical movement of the troughs and ridges, much like the keys of a piano keys, occurred.

The inversion is also proved by the fact that in the southern trough, above the Mid-Hungarian Tectonic Lineament (formerly published also as Zagreb-Kulcs or Kapos Line), the Inke-Igal Ridge and the depressions of the accompanying North and South Somogy Foreland already came into being at the end of the Karpatian. In the northern trough system, the Mihályi Ridge, following the Rába Line, only began to emerge more intensely during the Lower Badenian (moving continuously up to the Pontian), but represents the mobility at different times of the two large facies area in the same way. This mobility at different times is also 


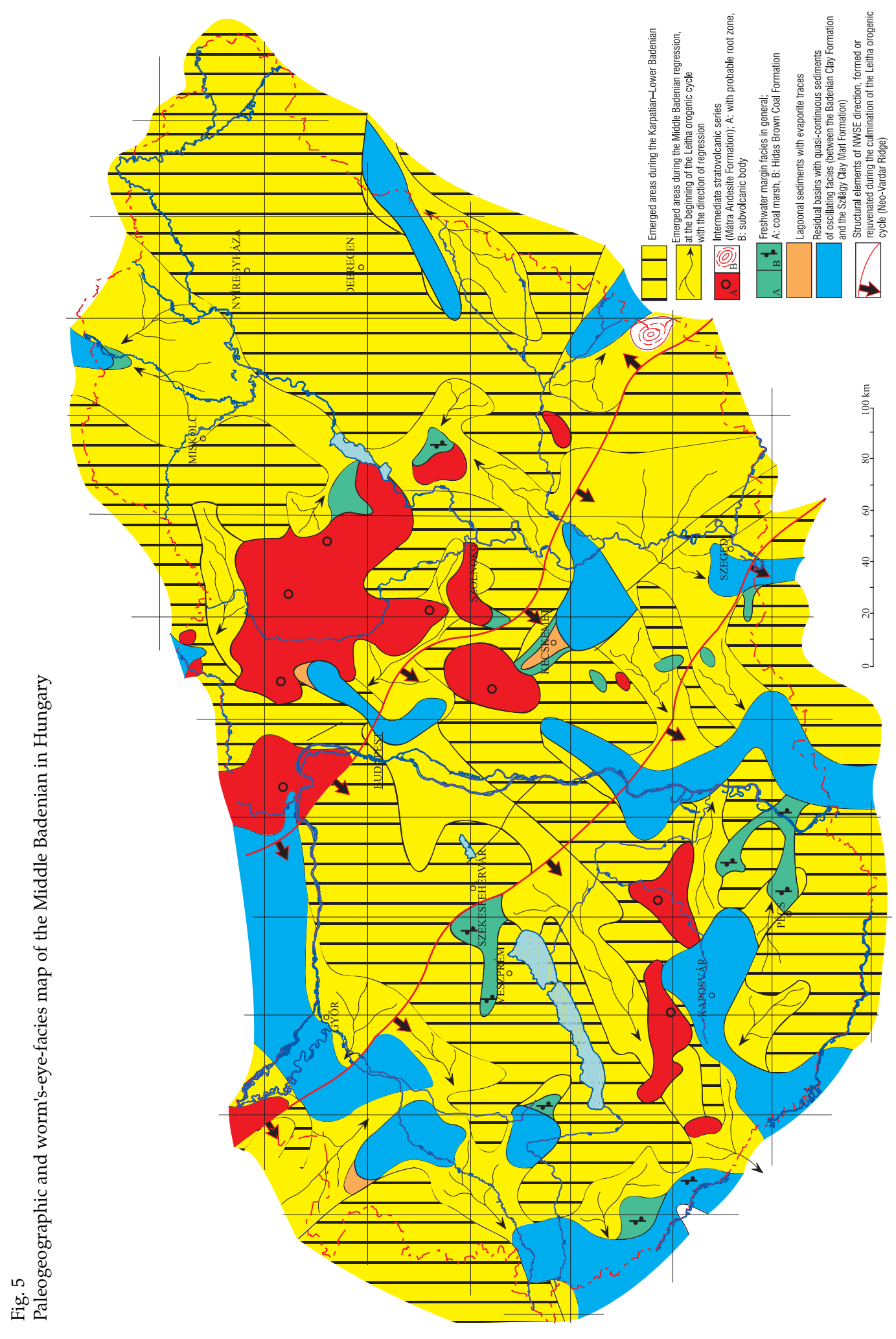




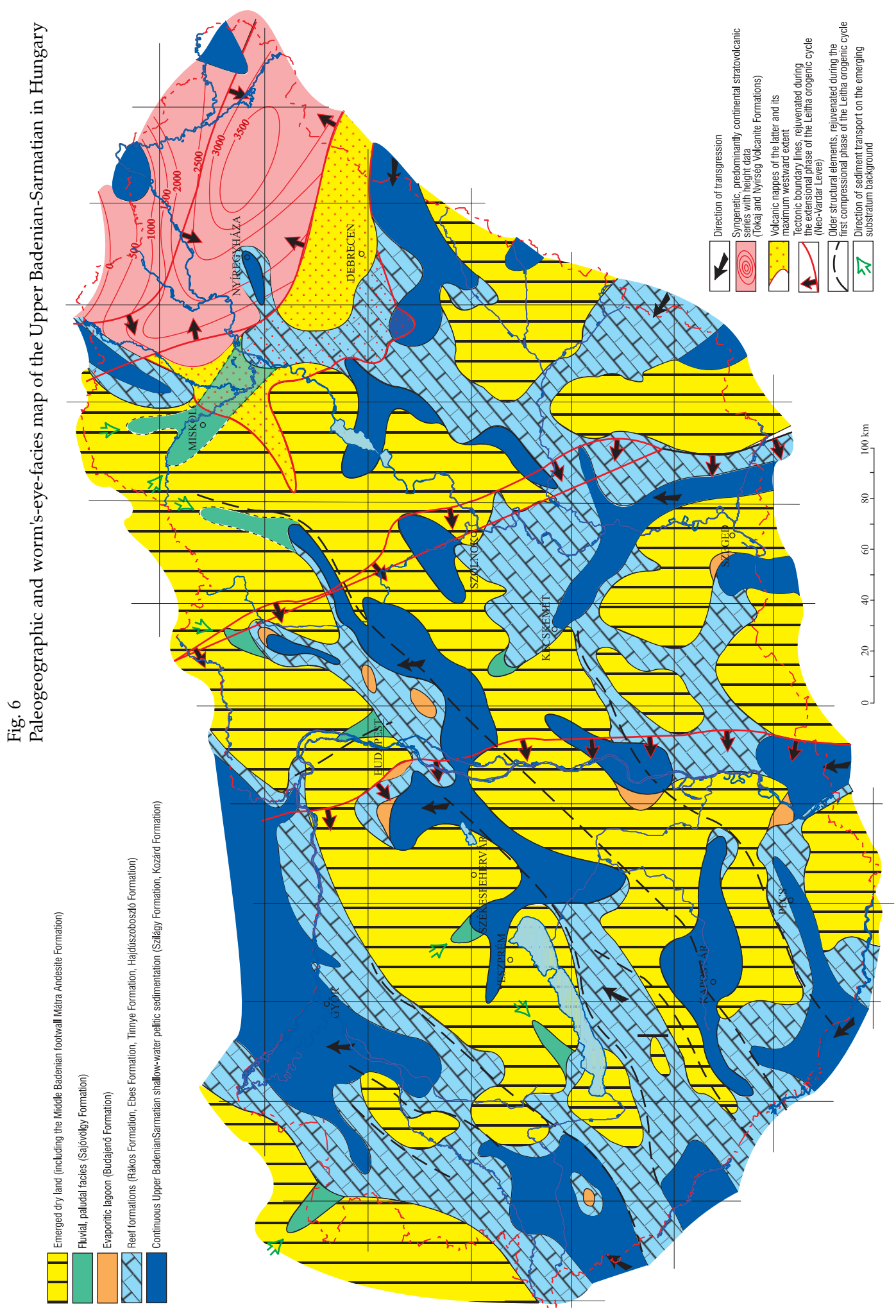


proved by the approach methods of layer statistics: the total thickness, the thickness conditions in the two types of stratigraphic situations, the extensions of the facies belts and the changes in their proportions in space, and finally the comparison of all of them to the same factors, averaged in the country-wide overview.

At the same time, data from all of the trough systems prove uniformly that the Karpatian sediment cycle is frequently characterized by turbidite-like sediment sequences of high energy basins, of narrower extent and indicating great paleomorphological differences (steep marginal slopes). The Lower Badenian conditions are characterized by more flattened reefal basins with strongly dissected margins that rapidly turn laterally into (generally) deep-water facies of undisturbed sedimentary environment. Both geologic supercycles ended with elevation and filling up through volcanic activity, intensifying through time. At the end of the Karpatian this is represented by the Mecsekjánosi and Fót Formations, as well as the Hasznos Andesite and Tar Dacite Tuff Formations, and at the end of the Lower Badenian by the Hidas Lignite Formation and the Mátra Andesite Formation (Fig. 5). It should be mentioned here that during the Early Miocene the Eggenburgian-Ottnangian geologic supercycle is closed by the Komló Andesite Formation.

\section{Late Miocene (Upper Badenian-Sarmatian-Pannonian-Pontian)}

The data of the Leitha orogenic cycle are presented in Table 6 and the maps in Figures 6, 7, 8. In Table 6, data of the Upper Badenian-Sarmatian and the Pannonian transgression cycles are summarized. The series of transgressions are closed by the Szolnok Sandstone Formation. According to the full-scale sedimentary evolution model of the Miocene-Pliocene clastic sequence (Juhász 1991), the inflexion point, i.e. the termination of the transgressive phase is rather at the bottom of the Szolnok Formation, representing the first sedimentary phase of a delta progradation (i.e. a regression).

In the Pannonian Basin, formed as a consequence of the intense orogenic movements of the Leitha orogenic cycle, three main facies areas, active up to the present, came into being during the Late Miocene. They are NW-SE-striking units, bordered by structural lines: the Western Pannonian Basin, the Neo-Vardar Ridge, and the Eastern Pannonian Basin. Their structural and paleogeographic situation corresponds nearly to that of the Early Miocene. A major difference, however, is that the earlier connections toward the western Mediterranean Basin were cut off due to the Leitha orogenic cycle.

During the Late Miocene, overlapping deposition has the greatest proportion among the three facies areas in the Eastern Pannonian Basin. Overlapping can also be detected during the Upper Badenian-Sarmatian-Pannonian. As a consequence of the repeated, though decreasingly intensive transgressions, during the Upper Badenian $84 \%$ of the rocks of the studied boreholes were deposited uncon- 
formably with hiatus on the substrate in this area, during the Sarmatian 52.8\%, during the Early Pannonian basal formations $32.3 \%$, and during the genesis of the Pontian delta system $21.6 \%$ explored formations. In the other two facies areas, one half or one quarter of these data is characteristic. The reverse of this tendency can be shown in the measured average thickness data of the above-mentioned time intervals in overlapping positions of the Eastern Pannonian Basin: 59-72-215 m. A similar picture is also presented by the averaged total thickness: it increases during the formation of the Sarmatian and Pannonian basal series, of the Pannonian deltaic series, and of the Pontian deltaic series, to an average thickness of 137-224-357-567 m.

Local anomalies are indicated by the $114 \mathrm{~m}$ thickness of the Upper Badenian in the Western Pannonian Basin, by the merely $33.3 \%$ of overlapping of the Sarmatian on the Neo-Vardar Ridge, by its $52 \mathrm{~m}$ average thickness, as well as by the similarly low average thickness $(74 \mathrm{~m})$ of the entire Sarmatian, as compared to the other partial areas and the global country-wide data for the Sarmatian. Apart from the anomalies, the statements in the above paragraphs can be explained by the accelerating subsidence of the basin basement: the extent of the newly drowned areas became increasingly smaller, reduced to one quarter, while the thickness average of all the sediments increased fourfold.

An issue that should be mentioned is that the country-wide summary of the Sarmatian and Pannonian basal layers appears with the same values in the table. The reason for this is that the interfingering of the Sarmatian-Lower Pannonian cannot be delimited in some localities, for instance in the case of the "Zala Striped Marls", where "oscillating" interfingering occurred during the given age due to repeated, small degree facies change. Difficulties of delimitation are caused by lack of data (several industrial boreholes were stopped in the formations of the Pannonian delta system) as well as the hypothesis of the "starved Sarmatian sea", based on the allegedly lacunar sequences. The apparent lack of the Sarmatian can be explained by the thin facies of its formations, since the boreholes without core sampling have between 200 and $400 \mathrm{~m}$ of non-evaluable section. In the investigated key wells this particular part of the sequences shows continuous sedimentation without hiatus and the arrangement of the facies belts in space is unchanged because the Upper Badenian and Sarmatian carbonate reefs are overlain by similarly calcareous Pannonian basal formations, while the the Upper Badenian and Sarmatian open marine-deep lagoon pelitic formations underlie Early Pannonian formations of the same facies. Thus, in the columns of countrywide summary the same values were interpreted. The studied factors and their trends show insignificant differences and the similarities are also confirmed by the Pontian comparative analysis of the Western Pannonian Basin, Eastern Pannonian Basin, and the Neo-Vardar Ridge (see Table 6 and Table 19).

Summarized data of the regional evaluation are presented also in Fig. 1.

In the further evaluation of the Late Miocene, the evolutionary history of the Hungarian part of the Pannonian Basin and the difference in the facies thickness 


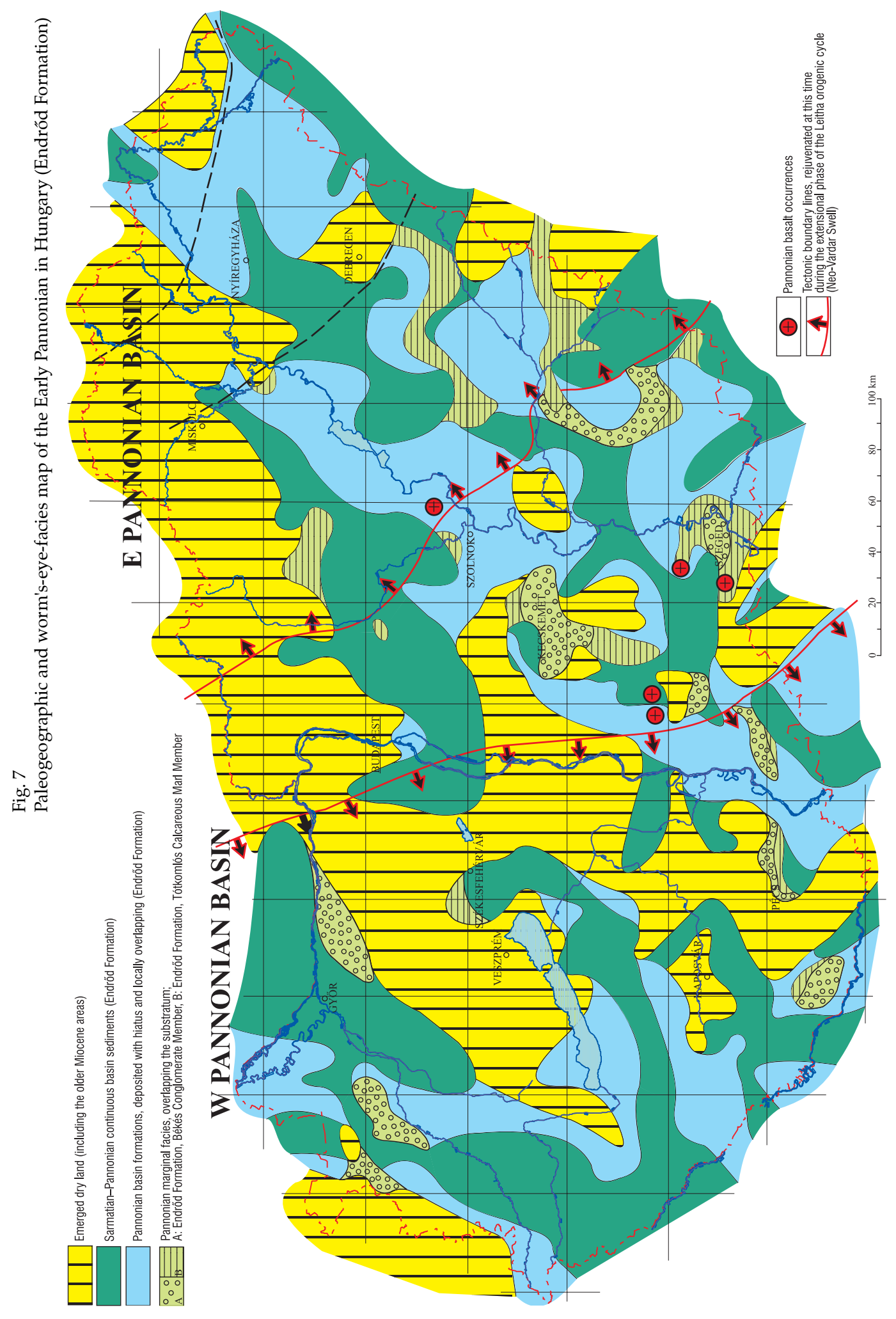




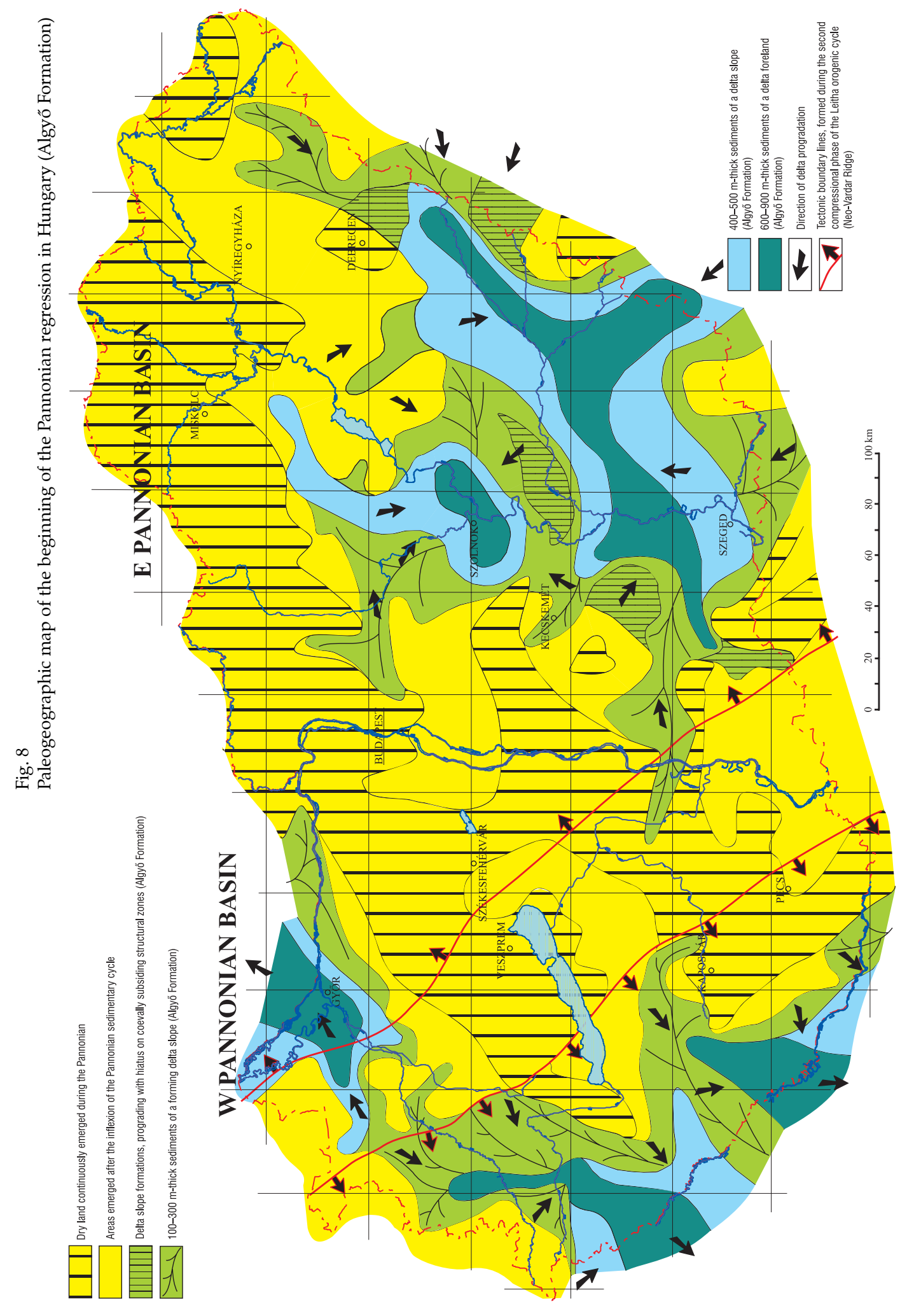


proportions of certain facies areas can be well traced. At the beginning of the Leitha orogenic cycle (Middle Badenian, Wieliczian), a predominant part of the territory of the country became dry land (Fig. 5). In a significant part thereof (mainly on the flanks of the Neo-Vardar Ridge), extensive andesite volcanism took place; this acted also as a uniform dry land, rarely as an emerged island or island series further out. In smaller partial areas, in residual basins, freshwaterpaludal formations were deposited (Hidas Lignite Formation).

This paleogeographic picture is recorded by renewed Late Miocene transgressions. Transgressive cycles, repeated from the Upper Badenian to the middle of the Pontian, originated from the S and SE (from the territory of the Eastern Paratethys). Transgressions from the south, via the Drava-Sava system, influenced the evolutionary history and facies conditions of the Western Pannonian Basin, and those from the SE through the passages of the Backa, Banat and the Transylvanian Range, decisively influenced the Eastern Pannonian Basin.

Columns 1, 2, 3, 4 and 5 of the Table 7 represent the ages, and within them the percentage of thickness of marginal facies compared to the total thickness in the given area and age, as well as the proportion of the increase of thickness of the basinal facies compared to the marginal thickness.

Comparing the above to the actual facies thickness data in Table 6, the following general conclusions can be drawn:

Table 7

Percentage of thickness of the Late Miocene marginal facies belts as a function of the total thickness in the given age, as well as the ratio of the coeval thickness of basinal facies in facies areas and country-wide summary

\begin{tabular}{|l|c|c|c|c|c|c|c|c|c|c|}
\hline \multirow{2}{*}{ Age } & \multicolumn{2}{|c|}{ Upper Badenian } & \multicolumn{2}{c|}{ Sarmatian } & \multicolumn{2}{c|}{ Pannonian base } & \multicolumn{2}{c|}{ Pannonian delta } & \multicolumn{2}{c|}{ Pontian } \\
\cline { 2 - 11 } & margin & basin & margin & basin & margin & basin & margin & basin & margin & basin \\
\hline $\begin{array}{l}\text { Western } \\
\text { Pannonian } \\
\text { Basin }\end{array}$ & $21.9 \%$ & $1.4 \times$ & $11.0 \%$ & $3.6 \times$ & $7.8 \%$ & $6.3 \times$ & $21.7 \%$ & $2.9 \times$ & $26.1 \%$ & $1.9 \times$ \\
\hline $\begin{array}{l}\text { Eastern } \\
\text { Pannonian } \\
\text { Basin }\end{array}$ & $19.0 \%$ & $2.4 \times$ & $33.2 \%$ & $2.2 \times$ & $11.9 \%$ & $3.9 \times$ & $38.9 \%$ & $1.2 \times$ & $23.3 \%$ & $2.1 \times$ \\
\hline $\begin{array}{l}\text { Country- } \\
\text { wide average }\end{array}$ & $19.4 \%$ & $1.8 \times$ & $11.5 \%$ & $4.0 \times$ & $11.5 \%$ & $4.0 \times$ & $27.8 \%$ & $1.6 \times$ & $22.6 \%$ & $2.2 \times$ \\
\hline
\end{tabular}

1. The thickness of the marginal facies decreases continuously between the Upper Badenian-Sarmatian-Pannonian basal layers up to the inflexion point of the Later Miocene cycle, in partial areas, as well as in the country-wide summary.

2. Coevally, the thickness of the basin facies increases continuously during the ages, two-, four- and sixfold compared to the marginal thickness, while in the Pannonian-Pontian delta system it decreases to a ratio of 3:2.

3. An anomaly appears only in the marginal facies belt of the Sarmatian age. The cause of the prominent thickness is that data of the boreholes drilled on the eastern margin of the Neo-Vardar Ridge were added to the western margin of the Eastern Pannonian Basin in the calculations. 
4. The explanation for items 1-3 is the continuous basin basement subsidence, with varying intensity, as well as the consequence of the Late Miocene structural formation and the connected infra-Pannonian inversion (at this time, the NeoVardar Ridge was activated as a levee, then - subsiding recurrently again - as a periodically active swell between the western and eastern areas).

5. The actual data dealing with the mobility of the facies areas indicate that, according to the data of the marginal facies of the geologic supercycle from the Upper Badenian to the Pannonian inflexion point and the Pannonian-Pontian delta system, the Western Pannonian Basin is more mobile. It has the thickness of the Upper Badenian marginal facies (more than one-fifth of the total thickness), the four- and sixfold thickness ratio of the basinal facies of the Sarmatian and Early Pannonian series, as well as the more than one quarter proportion of the Pontian marginal facies. At the same time, this means that beginnings of the Leitha and Rhodanian orogenic cycles were more intense in this area. This is also reflected by the continuous and repetitive basin formation process.

6. Accordingly, the transgression was stronger in the Drava-Sava system; the position of the shoreline was practically unchanged between the Sarmatian and Pontian, and the fluvio-deltaic hinterland formations (appearing not in layer statistics, only in certain sections) can be also found here (Sopron-Tómalom, Szombathely, Toronyi lignite areas). The tectonic situation of the facies area is characterized by the fact that it can be considered a foreland depression that came into being, partly due to the interaction between the eastward overthrust of the Eastern Alpine system and the very mobile Transdanubian Range Unit around the Rába Line, and partly in the forelands of the thrust zone around the South Alpine-Dinaridic Unit and the Mid-Hungarian Lineament (Northern and Southern Somogy Troughs). The average thickness of Late Miocene in the Western Pannonian Basin is $1,234 \mathrm{~m}$.

7. The separation of the Western Pannonian and Eastern Pannonian Basins became increasingly pronounced through repeated mobilisation of the NeoVardar Ridge in the Sarmatian. Due to the smaller area merge (merging of the eastern Neo-Vardar area and the western marginal Sarmatian epicontinental facies of the Eastern Pannonian Basin) already mentioned, this area holds a leading position among the marginal facies, with a prominent thickness value $(33.2 \%)$. The marginal and basinal facies ratio of the Pannonian basal series can be characterized by a 1:4 proportion. The thickness of the marginal and nearmarginal facies belt of the Pannonian delta series (Algyő Formation) is $28.9 \%$, that is nearly one-third of the total thickness. In addition, the delta is composed of several beds: the thickness of the deep water channel sediment (Szolnok Formation; $35.3 \%$ ) as well as the interfingering sediment system of the delta foreland $(38.5 \%)$, not divisible into formations, are also remarkable.

8. Thus, it can be stated that in the second and third phases of the Leitha orogenic cycle, the Eastern Pannonian Basin was more mobile. Within it, facies of slightly different thickness came into being in the NW-SE-vergent trough 
systems, developing during the westward shift of the Neo-Vardar Ridge (e.g. Kada Trough at Kecskemét-Hódmezôvásárhely-Makó Trough-Kikinda Trough, or the elevated Battonya Ridge, Békés Basin).

This is also confirmed by the facies thickness of the delta system in the Pontian. At the Neo-Vardar Swell, a prominent part $(33.8 \%)$ of the total thickness is composed of the Úffalu Formation of delta forehead-deltafront facies. The undivided basin fill has its greatest thickness in the Eastern Pannonian Basin $(1,148 \mathrm{~m})$. Compared to the Western Pannonian Basin, an important difference here is that the amount of the Sarmatian and Pontian continental sediments (Sajóvölgy Formation, Zagyva Formation) is more significant than in the west.

9. The Late Miocene average total thickness in the Eastern Pannonian Basin is $1,344 \mathrm{~m}$. Compared to the Western Pannonian Basin, this is only a slight difference (about $100 \mathrm{~m}$ ) that may have also been caused by unevenness of the paleorelief. In balance, an equal role is played by the Újfalu Formation, still containing marine intercalations, and the continental Zagyva Formation.

In summary it is obvious that at this time the stronger transgression effect was from the SE, through Transylvania, and to a smaller degree via the Lower Danube-Timok Trough, to the Eastern Pannonian Basin with its rapidly subsiding basement. The basement is composed of ENE-WSW-striking megastructural units with thrust zones (south-vergent thrusting). In the interval prior to the evolution of the Pannonian delta system of the Late Miocene, these structural zones are clearly-indicated by the Upper Badenian-SarmatianPannonian initial reef formations that stepped over and continuously covered these paleocrests with reefs during several small transgressional cycles. In the intermediate areas coevally open marine, shallow water, or deep-lagoonal basin sediments developed (Szilágy Clay Marl Formation, Kozárd Formation, Endrőd Marl Formation). The episodic regression of the Sarmatian created evaporitic lagoons in the Western Pannonian Basin and - due to the expansion of dry land - fluvial sediments as well as algal, diatomaceous layers, indicating the closure of smaller bays, in some locations in the Eastern Pannonian Basin, mainly in the northern margin region (Cserhát, Tokaj Mts).

10. In both facies areas, and also on the Neo-Vardar Ridges, the evolutionary history picture became more uniform after the infra-Pannonian inversion (Figs 7 and 8). This means that basement subsidence ended with the deposition of the deep-water Szolnok Formation, and slow hinterland elevation began, which is represented by the series of delta slope facies of the Algyő Formation. At this time, the hinterland elevation was stronger in the surroundings of the Eastern Pannonian Basin. Sediment transport proceeded from the Eastern Carpathians, the Transylvanian and Hungarian inselbergs, as well as the Neo-Vardar Ridge, toward the area of the main basin in the Trans-Tisza area. It can be interpreted as a unique phenomenon that the coevally-arriving transgressions and their Eastern Paratethyan fauna and flora associations meet and interfinger with the formations, fossils of the delta systems here. 
From a structural standpoint, however, it is remarkable that the Pontian delta system also covered the Neo-Vardar Swell with the facies of the last "marine" delta fronts, representing here the highest percentage (33.8\%) of the countrywide total thickness of the Pontian. At the same time, fluvio-paludal series of the delta hinterland (Zagyva Formation) were deposited on both flanks of the NeoVardar in nearly identical thickness, fully eliminating any remaining paleorelief differences. It should be mentioned that the subsidence of the Eastern Pannonian Basin continued even thereafter, which is also proved by Quaternary sediments of great thickness (around 1,000 m; Nagyalföld Variegated Clay Formation).

\section{Faciological and paleogeographic results}

A fundamental condition of the formation-statistical method is that it is possible to detect, document, and extensively interpret the material results of the coeval events instead of the chronostratigraphic boundaries, which are difficult to define and also change through time as a result of changes in systematics. During the investigations it was attempted to approach this issue mainly by choosing proper markers (unconformities, syngenetic volcanic tuff levels, perhaps some striking global events or changes), using $\mathrm{K} / \mathrm{Ar}$ absolute age determination methods, or measuring magnetostratigraphic key sections.

Of course the biostratigraphic and chronostratigraphic data have not been neglected; however, the quantitative data collection was focused on the lithology and lithostratigraphy.

For that very reason, the fact that the lithostratigraphic aspects of formationstatistical results do not basically contradict the chronostratigraphic data is held to be a most important result. At several levels they support and confirm them with truly objective data, and the opposite is also the case. The contradictions of rigid biostratigraphic delimitations are mostly precisely resolved by the paleoenvironmental as well as vertical and lateral facies transition connections established in the course of these investigations - by the quantitative weighting of the prevailing fauna assemblages and flora associations.

\section{Methodological results}

In the course of the consistent work of decades, by becoming acquainted with the (possibly total) sequence of the Hungarian Neogene by means of detailed observation and publishing the knowledge acquired in this fashion in specialized literature, it was possible to develop a continuous and logical system of detecting (measuring)-calculating-illustrating, as well as the methods required for its technical realization.

Creating the basic data system required collecting every datum, measuring it metrically or in other ways and expressing it numerically. The most important elements, although by no means all of them, are stratigraphic condition, litho- 
logical and facies data (grain size, matrix, layer, bed, member, formation and facies thickness, and separately the thickness of the interfingering of the facies belts), characteristic sedimentological features (cyclicity, turbidite bedding, carbonatization, laminitization and microbedding, mud movement traces, biostructures, resedimentation, desiccation and evaporite traces, and carbonization), igneous events and biofacies phenomena; size, frequency of "events" (number of specimens, number of taxa, size of specimens, fauna waves, enrichment of vegetation, etc.).

The evaluation and interpretation of data occurred on the basis of calculations. Their results are expressed in various ways: arithmetic average, number of units being considered, frequency percentage or ratio and proportion. During the collection of the basic data and calculations, data of variable value and reliability, and sometimes even incomplete data, became usable if a sufficient amount of data was available. The system smoothes the rough differences or errors derived from observations by different authors at different times and using different methods; at the same time knowledge was increased by a huge mass of information.

Thereafter, the results of the calculations are grouped into space-time systems proper for the objectives of the study. A natural unit of chronological grouping may be a layer, formation, sampling point, or a lithostratigraphic or chronostratigraphic unit. It could, however, also be a sedimentary cycle, orogenic phase or cycle, and total time span of several cycles. Grouping in time may be carried out within partial areas, geographic units, facies areas, tectonic units, regions and interregional areas. A basic method of calculation is that averaging must be started, as well as restarted, at the level of elementary data for every space-time unit; thus, for example, no average of averages or percentage of percentages, etc., will be taken into account.

By means of the vertical elements of this system event history, the evolutionary history and total geologic arrangement can be documented and interpreted, and structural formation, dynamic facies and environmental change by means of its lateral elements.

Thickness development, frequency of preferred phenomena, and sedimentation rate are expressed by absolute numbers, and characterization of, and changes in, composition and mass ratio in percentages (e.g. for documenting lithostratigraphic and facies units). Intensity of geodynamic processes (proportion of overlapping transgressions in comparison to each other, proportion of sediment mass of geologic supercycles in relation to each other), degree of lateral changes, and facies proportions within the basin, size and paleomorphology of the basin volume (by creating numerical offshore and isorhythmicity indices; Hámor 1983) are given as ratios. The calculation methods certainly vary, and can be combined with each other, depending on the scale (scale relations) of work and the state of exploration and laboratory-derived knowledge. 
"The proof of the pudding is in the eating." With this eternal saying we intend to express that though the data in the tables provide a lot of information in themselves, the creation of the graphic documentation, representation, and interpretation systems is also considered to be a result of the method development. Among these, the vertical and lateral (that is, established in the same time and space) parallel, multicomponent facies diagrams and the paleoreconstruction maps of sub-basins, calibrated by sediment cycles (Hámor 1970: Eastern Mecsek; 1983: Nógrád-Cserhát), as well as the detailed paleogeographic and facies maps of other areas (Hámor 2001a, 2005:), built entirely on quantitative data series, are newly established systems.

A methodologically new element of paleogeographic maps of country-wide (regional), interregional, and continental scope (Hámor 1997: Hungarian Neogene; 2001a: Carpathian Basin Neogene; 1989: (Ed.) Neogene paleogeographic maps of Central and Eastern Europe) is the representation of lithofacies, biofacies and geofacies of any single given time on one sheet, and their publication, documented in 5-7 time intervals, in a dynamic atlas format.

Last but not least, the versions of the manuscript "The worm's-eye-facies and paleogeographic maps of the Hungarian Neogene (versions 1-6)" at a scale of 1:500,000 must be mentioned, built on quantitative layer-statistical data and more directly suitable for further utilization as a prognostical tool; these are published in a reduced form in the present study. Their documentative novelty is provided by the layer-statistical results of this publication.

\section{Faciological observations, results and regularities}

One element of the results obtained is that it was possible to define and prove practically every facies unit of the Hungarian Neogene and their spatial relationships (lateral facies transitions, interfingerings) using quantitative data. By way of introduction, it is important to note that the results can be evaluated and presented in two different groups: on the level of detailed investigations, and as country-wide summaries. The completeness of the data does correspond to these two scales. The scales of the detailed investigations are 1:10,000, 1:25,000 and 1:50,000, while those of the overview evaluations range from 1:100,000 to $1: 500,000$ or from $1: 1,000,000$ to $1: 1,500,000$. This allows for correct resolution in all cases.

The detailed faciological investigations indicate predominantly the preferred points of the sedimentary cycles, that is the start-of-cycle (transgressional basal formations) or end-of-cycle formations (regressional series and phenomena). The geofacies, quantified as part of the present study, and the details within them, are as follows (with the indication of the geographic place of the detailed investigation and/or the lithostratigraphic units, which provide the proof).

In the series of continental sedimentation: 
- Within the fluvial facies, the following facies belts can be distinguished: channel, coastal bar, levee, flood plain, paludal, swamp (Mecsek-SomogyDanube-Tisza Interfluve, Szászvár Formation; Eastern Mecsek, Szászvár Formation, Mecseknádasd Member; North Hungarian lignite areas, Salgótarján Lignite Formation).

- In the fluvio-paludal facies, the regressive branch of the total geologic supercycle can be demonstrated (Eastern Mecsek, Szászvár Formation, upper part of the Máza Member, upper part of the Mecseknádasd Member).

- In the fluvial facies the geologic structure of the intake area, transport distance, location of confluence of tributaries, lateral extension and displacement in time of the facies belts (facies migration), as well as the change in the section character of the river can be proved at some locations, in the region of the tectonically preformed sediment traps.

Remarkable data were obtained on the lateral interfingering of the continental and marine basins (Western Mecsek, between the Mánfa Member of the Budafa Formation and the Keresztúr Formation; Cserhát Mts-Zagyva Trough, between the Sajóvölgy Formation and the Kozárd-Tinnye Formations; Sopron Mts-Tómalom, between the Sajóvölgy Formation and the Tinnye Formation)

In vertical sections, well-characterized fluvio-deltaic transitions can be demonstrated (beside the areas mentioned in the previous paragraph, in the Tordas Member of the Zagyvapálfalva Formation, Cserhát Mts; in the Nagyorosz Gravel Formation, at the Slovakian-Hungarian border, Börzsöny Mts).

In the area of marine sedimentation:

- In the lateral facies sequence of the start-of-cycle marine transgression, positioned according to Walter's facies law and migration in estuarine time, abrasion shore, flat shore, foreland lagoon, and bay-closing reefs can be proved (the example of the Mecsek Mts is presented below and in Table 8).

- The paleogeographic reconstruction of the basin at maximum marine transgression can be documented with the position of transgressional cycles in space, the displacement of heteropic facies in time, and the isorhythmicity and offshore indices. Paleorelief can be represented on the basis of the quantitative evaluation of the sedimentological factors, and the biofacies on the basis of the paleontological data.

- The regressive flanks of the sedimentary cycles can be detected in marine environments; this can be well correlated with the parts of the same evolutionary tendency of coeval continental series.

- On the basis of detailed quantitative faciological investigations, the objective evaluation of Karpatian, Badenian, Sarmatian, and Early Pannonian reef formations became possible with the determination of age classification, heteropic facies, paleoenvironment and actual reef sizes. 
Table 8a

Results of the layer statistical investigation of the Komló-Mánfa Bay in comparison with the data of the similar formations of the Cserhát-Zagyva Trough (Table 8b)

\begin{tabular}{|c|c|c|c|c|c|}
\hline Formations & \multicolumn{3}{|c|}{ Budafa Formation } & $\begin{array}{c}\text { Tekeres } \\
\text { formation }\end{array}$ & $\begin{array}{c}\text { Karpatian } \\
\text { in total }\end{array}$ \\
\hline Members & $\begin{array}{c}\text { Pécsvárad } \\
\text { Mb. } \\
\text { (Congeria) } \\
\end{array}$ & $\begin{array}{l}\text { Komló Mb. } \\
\text { (fish-scale) }\end{array}$ & $\begin{array}{l}\text { Mánfa Mb. } \\
\text { (Budafa } \\
\text { Sandstone) }\end{array}$ & $\begin{array}{c}\text { Tekeres Mb. } \\
\text { (Tekeres Schlier) }\end{array}$ & \\
\hline $\begin{array}{l}\text { Evaluated linear metres } \\
(\mathrm{m})\end{array}$ & 281 & 3,669 & 3,924 & 1,438 & $8,312 \mathrm{~m}$ \\
\hline $\begin{array}{l}\text { Total number of boreholes } \\
\text { (pcs) }\end{array}$ & 30 & 35 & 23 & 13 & $101 \mathrm{pcs}$ \\
\hline $\begin{array}{l}\text { Boreholes, reaching the } \\
\text { substratum (pcs) }\end{array}$ & 26 & 0 & 3 & 0 & $29 \mathrm{pcs}$ \\
\hline Average thickness (m) & 9.4 & 105 & 171 & 110 & $92 \mathrm{~m}$ \\
\hline Overlapping thickness (m) & 9.7 & 98 & 74 & 0 & $70 \mathrm{~m}$ \\
\hline Continuous thickness (m) & 7.0 & 114 & 329 & 307 & $124 \mathrm{~m}$ \\
\hline $\begin{array}{l}\text { Percentage of Karpatian } \\
(\%)\end{array}$ & $2.4 \%$ & $26.5 \%$ & $43.2 \%$ & $27.8 \%$ & $99.4 \%$ \\
\hline $\begin{array}{l}\text { Facies } \\
\text { Thickness (m) }\end{array}$ & $\begin{array}{c}\text { Estuary } \\
8.4 \\
\end{array}$ & $\begin{array}{c}\text { Lagoon } \\
106 \\
\end{array}$ & $\begin{array}{c}\text { Shore } \\
201\end{array}$ & $\begin{array}{c}\text { Basin } \\
307 \\
\end{array}$ & Increasing \\
\hline $\begin{array}{l}\text { Ratio of change in } \\
\text { thickness }\end{array}$ & 0.1 & 1 & 2 & 3 & Increasing \\
\hline
\end{tabular}

Remarks: The fish-scale clay marl and the Budafa Sandstone interfinger in a thickness of $77 \mathrm{~m}$; this is about $17 \%$ of the two sequences. As during the transgression the individual members get above each other, by the end of the cycle the total thickness is $181 \mathrm{~m}$ in the bay (in near-margin position) and 754 $\mathrm{m}$ in the initial part of the basin. This means a fourfold increase in the direction of the basin and shows an approximate area proportion at the same time (see overlapping and continuous thickness rows).

Table $8 \mathrm{~b}$

Results of the layer statistical investigation of Karpatian formations of the Cserhát-Zagyva Trough from faciological aspect

\begin{tabular}{|l|c|c|c|c|c|}
\hline \multicolumn{1}{|c|}{ Formations } & \multicolumn{3}{|c|}{ Egyházasgerge Formation } & $\begin{array}{c}\text { Gaáb } \\
\text { Schlier } \\
\text { Formation }\end{array}$ & $\begin{array}{c}\text { Karpatian } \\
\text { in total }\end{array}$ \\
\hline Members & Kazár Mb. & Mátranovák Mb. & $\begin{array}{c}\text { Egyházasgerge } \\
\text { Mb. }\end{array}$ & Garáb Mb. & \\
\hline $\begin{array}{l}\text { Facies } \\
\text { and thickness (m) }\end{array}$ & $\begin{array}{c}\text { Estuary } \\
25\end{array}$ & $\begin{array}{c}\text { Lagoon } \\
40\end{array}$ & $\begin{array}{c}\text { Shore } \\
242\end{array}$ & $\begin{array}{c}\text { Basin } \\
573\end{array}$ & Increasing \\
\hline $\begin{array}{l}\text { Ratio of change in } \\
\text { thickness }\end{array}$ & 0.6 & 1 & 6 & 14 & Increasing \\
\hline
\end{tabular}


Case studies on the detailed quantitative evaluation of the molasse sedimentation of Karpatian age

\section{Mecsek}

In the series of case studies, the Eastern Mecsek in general and the MánfaKomló Bay in particular, shown below, is the type area of the basically quantitative paleogeographic reconstruction of the early transgression phase.

The transgressive cycles coming from the SW (from the Mediterranean) reached the northwestern margin of the Mecsek Mts through the Karlovac Trough-Drava Basin via the Southern Somogy Trough (Kadarkút). The NW-SEdirected Villány-Szalatnak normal fault, forming the boundary between the Western and Eastern Mecsek, still acted as a NW-vergent fluvial transport channel in the Ellend-Pécsszabolcs-Mánfa, and Árpádtetó Lines at the beginning of the cycle (Keresztúr Formation). The shore of the sea, invading the rocky marginal coastline and the estuaries, was formed by Triassic carbonates in the west and Cretaceous alkaline diabase - in the surroundings of Komló Early Miocene andesite - in the east. Their small-grained debris forms a several $\mathrm{cm}$-thick basal detritus. The main rock mass is composed of Congeria lumachelle layers with a matrix of thick-bedded limestone and sandy limestone, built up by Congeria specimens, which were attached to, or in some places etched into, the rocky coast (Budafa Formation, Pécsvárad Member). At the bottom of the coastal slope the faunal picture is completed by Neritina, Bulimus and Brotia mollusk fauna. Moving offshore the basal detritus thins out or spreads in a fishtail structure within 10-100 $\mathrm{m}$, in the form of sandstone beds and faunal sand layers. These, as well as the mentioned gastropod fauna, represent the lateral litho- and biofacial transition and interfingering with the series of deep lagoons of the foreland depressions, still semi-saline at the beginning and alternating more and more frequently with marine ingression layers upsection. Twenty-five to fifty percent of their $100-300 \mathrm{~m}$ thick, predominantly (70-98\%) pelitic formations are seasonally micro-layered, with mud movement traces. Though not in the latter, on the bedding planes of the homogeneous layers fish scales and remnants are characteristic (in the literature "layer cake beds", "fish-scale clay marl"; today Komló Clay Marl Member of the Budafa Formation). The position of the lagoonal systems and their thickness, correlating with the basement relief, and that of the mud movement traces in space, prove the mobility of these zones, as do the boundary faults at the mountain margins and the tectonic situation of the depression series, parallel to the coastline.

In their evolutionary history a significant role was played by the detectable sand levees, flat shore dune sequences, and flank deposits of deltas that separated them from the open water, at first periodically and then permanently. Storm tides, linked to monsoon periods, splashed over these levees - causing a poor foraminifer and rich fish fauna influx in the calm bays where mostly only the fish-scales were fossilised (today, this phenomenon is used every year by the 
fishermen of the Malaysian Islands for a rich catch, concentrated under the same conditions).

These classic longshore facies belts are covered by the formations of the already littoral facies belts of the subsequent - stronger - transgressional cycle. They belong to the Mánfa Member of the Budafa Formation (sandstone with psammite content above 50\%) that interfingers vertically with the Komló Clay Marl Member in a thickness of $30 \mathrm{~m}$, or even $120 \mathrm{~m}$ in some places. This makes up about $20-25 \%$ of the total Karpatian transgressional complex thickness. Rarely, where the newer cycle enters the realm of the substrate, the Mánfa Member developed in the form of abrasional gravel conglomerate with calcareous cement. In fluvial influx areas, most frequently as a linear transition of the Keresztúr Formation, thick-bedded, cross-bedded delta facies came into being, built up by sand, sandstone beds and concretions with pelite-calcareous mud intercalations on its flanks and rare marine fauna elements. In its lateral transitions, littoral sandstone and silty sand rock varieties can be found.

In the near-shore areas, covered uniformly by open, gradually deepening water, and showing strong current features in off-shore deeper water environment due to basement subsidence and transgression, a schlier complex came into being. This is the Tekeres Schlier Formation that is composed of the rhythmic and cyclic alternation of pelitic-fine sandy-micaceous well-bedded formations. Its macro- and microfauna is rich; an alternation of associations follows the sedimentary cycles.

The layer-statistical investigations clearly demonstrated (see Table 8):

a) the veracity of facies migration according to Walter's facies law, as these units were deposited above each other for the period of the maximum transgression of the cycle;

b) the heteropic nature of the mentioned formations, members and their facies. This is proved by the structural and areal connections of the paleomorphological changes, the correlatable cyclicity of sedimentation in the individual facies, the topographic separation and co-existence of depocenters (maximum development of thickness) of the individual facies, the interfingering lateral facies transitions, and the regularities of the tendencies of the formation and layer thickness to change. Heteropicity is also supported in an absolute way by the stratigraphic conditions of the "Middle Rhyolite Tuff" (Tar Dacite Tuff Formation) marker, proving coevality (Table 4);

c) At the end of the sedimentary cycle, during the regression, vertical facies changes were repeated in inverse order, both in the marginal and basinal areas. Above the schlier complex, the Budafa layers with fish-scales and Congeria appear again; the cycle is then closed by the Mecsekjánosi Beds of the Fót Formation, with total subaerial exposure. 
d) Further data are provided by the correlatable biomarkers of the individual facies (nannoplankton zones, certain benthonic and planktonic foraminifer associations, diatom intercalations, as well as the spore-pollen spectrum).

It should be noted here that, due to the outside marginal position of the model area and the focus of the investigation on the initial events of the transgression, the data of Table 8 on the Tekeres Schlier Formation characterize only the boundary area, and are presented only with the aim of comparison. Further details can be found in the monographic summary of the Neogene of the Eastern Mecsek Mts (Hámor 1970).

\section{Nógrád-Cserhát area}

The next case study below presents a brief summary of the quantitative paleogeographic reconstruction of the Nógrád-Cserhát area and within it the Zagyva Trough, representing the basinal facies of its total Karpatian transgression cycle, together with the evaluation of the end-of-cycle regressional flank.

The Zagyva Trough is the S-SE zone of the North Hungarian PaleogeneNeogene Basin. Its genesis was determined by the NE-SW-vergent structural zone, parallel to the Darnó system and presumably separating the Transdanubian Range and Bükk tectonic subunits, in the old Styrian orogenic cycle. At its northeastern end it is bordered by the older system (developed in the Savic orogenic cycle) of the perpendicular Etes Trough, although in some places its extent also reaches the older structure and overprints it. The example area is situated approximately in the Salgótarján-Pásztó-Szécsény triangle.

The Karpatian transgression, advancing from the SW, thins out northeastward. Compared to the Mecsek model area, the important differences are as follows: the footwall series are composed of Oligocene-Early Miocene loose rocks, fluvial start-of-cycle formations of the cycle are not known, there are no rocky coast estuaries, longshore lagoons are rare, and no delta systems were developed.

The basement morphology here is more balanced, or more "flattened"; however, the degree of basement subsidence is greater, and the maximum and regressive phase of the Karpatian sedimentary cycle developed more completely.

A further important difference is that in the sample area, sedimentation is continuous in the Early Miocene (Ottnangian) Salgótarján Lignite Formation, though with a measurable angular discordance. Here the basin, which developed due to rapid subsidence, was invaded by a transgression almost without obstacle and the status of the individual facies belts stabilized faster. This is wellcharacterized by the facts that thickness of the interfingering transitional lithofacies is less, and the lateral connection of the biofacies belts (CongeriaOnchopora-Anadara-Paphia-Chlamys-Nautilus facies series) is more continuous.

From a layer-statistical standpoint, the most characteristic differences of the sedimentation of molasse type as well as the structure, water depth conditions, 
and facies distribution of the basin, however, are documented excellently by the real and average thickness data and the ratio and direction of change within them. This is supported by the data in the last four rows of Table 8 where the change takes place according to mathematical progression in the "tectonics free" bay and according to geometrical progression in the structurally preformed trough.

\section{Regularities of the sedimentation of molasse nature}

These regularities are confirmed by the enumeration and documentation of the provable identical factors in both model areas, the increasing facies areas, and also in the country-wide summary:

- the tuff markers, rendered more precise by K/Ar absolute age investigations, can be used as isochronous surfaces both in the partial areas and the greater units of regional scale;

- the vertical succession of facies zones and the lateral transition of facies belts appears uniformly everywhere within the thus designated time unit;

- the thickness ratios were developed in the case of overlapping and continuous position; consequently the proportion of average thickness and lateral thickness changes can be evaluated in the same way;

- the course of the total geologic supercycle is identical; the distribution of the sediment mass according to formations-members as well as facies proportions, seems to be regular within the Karpatian complex (see Table 9).

\section{Table 9}

Sedimentary regularities of the Karpatian geologic supercycle according to the mass proportion of average thickness in partial areas and the facies zones

\begin{tabular}{|c|c|c|c|c|c|}
\hline \multicolumn{2}{|c|}{ Eastern Mecsek } & \multicolumn{2}{|c|}{ Cserhát-Zagyva } & \multirow[b]{2}{*}{ Facies belts } & \multirow{2}{*}{$\begin{array}{l}\text { and their } \\
\text { proportion }\end{array}$} \\
\hline $\begin{array}{l}\text { Average thickness } \\
\text { of the unit }(\mathrm{m})\end{array}$ & $\begin{array}{l}\text { Percentage of } \\
\text { Karpatian (\%) }\end{array}$ & $\begin{array}{l}\text { Average thickness } \\
\text { of the unit }(\mathrm{m})\end{array}$ & $\begin{array}{l}\text { Percentage of } \\
\text { Karpatian (\%) }\end{array}$ & & \\
\hline $\begin{array}{l}\text { Pécsvárad Mb. } \\
8 \mathrm{~m}\end{array}$ & 1.2 & $\begin{array}{c}\text { Kazár Mb. } \\
25 \mathrm{~m}\end{array}$ & 2.7 & Estuary + & \\
\hline $\begin{array}{l}\text { Komló Mb. } \\
106 \mathrm{~m}\end{array}$ & 16.2 & $\begin{array}{c}\text { Mátranovák Mb. } \\
40 \mathrm{~m}\end{array}$ & 4.8 & Lagoon $=$ & $20 \%>$ \\
\hline $\begin{array}{l}\text { Mánfa Mb. } \\
201 \mathrm{~m}\end{array}$ & 30.8 & $\begin{array}{c}\text { Egyházasgerge Mb. } \\
242 \mathrm{~m} \\
\end{array}$ & 26.4 & Shore $=$ & $25-45 \%$ \\
\hline $\begin{array}{l}\text { Tekeres Fm. } \\
307 \mathrm{~m}\end{array}$ & 47.0 & $\begin{array}{c}\text { Garáb Fm. } \\
573 \text { m }\end{array}$ & 62.6 & Basin $=$ & $45-65 \%$ \\
\hline $\begin{array}{l}\text { Mecsekjánosi Mb. } \\
30 \mathrm{~m}\end{array}$ & 4.6 & $\begin{array}{l}\text { Fót Fm. } \\
35 \mathrm{~m}\end{array}$ & 3.8 & $\begin{array}{c}\text { End-of-cycle } \\
\text { uplift }=\end{array}$ & $10 \%>$ \\
\hline $\begin{array}{l}\text { Total } \\
652 \mathrm{~m}\end{array}$ & 100 & $915 \mathrm{~m}$ & 100 & & \\
\hline
\end{tabular}

Remarks: The proportion of the start-of-cycle and end-of-cycle facies is below $10 \%$ in the tota Karpatian sediment sequence in both areas. Adding up crosswise the incomplete data of marginal and basinal facies proportions, a 90\% value is obtained in both areas; this means that the corresponding formations came into being in heteropic facies at almost the same time, and they are in contact with a surface of approximately 45 degree inclination in the graphic model (but also in reality). 
Remaining with the example of the Karpatian geologic supercycle, the differences in thickness and the tendency of regularities are also supported by the identifiable number of medium and small cycles within the supercycle. In both areas, 5 medium cycles can be identified layer-statistically, and this data can also be extended country-wide on the basis of the analogies. Of the 5 medium cycles, 3 are transgressive and 2 regressive ones, and are built up by a varying number of equally transgressive and regressive small cycles; it appears that the higher unit is determined by their quantity proportions. The basis of their statistical utilization is that cyclicity is a function of the mobility, slope conditions, current system and intensity of the given zone. On the basis of these and the frequency evaluation of the sedimentological and biological events, a compilation of facies and paleogeographic maps can be carried out on the basis of objective data Thanks to them isocyclicity and isodynamical lateral zones can be designated. The iso-offshore indices, based on the sand-pelite ratio of certain medium cycles and their horizontal changes (Hámor 1983), have a similar objective. They form an important basis for designating the coastline as they help in tracing out the facies belts running parallel with the coastline, and closing concentrically. By using them and extrapolating up to the coastline, quantified (and thus basically objective) paleogeographic maps can be compiled.

Regularities of the molasse sedimentation on the basis of comparative investigation of different area units

The characteristics of the molasse sedimentation of the Karpatian geologic supercycle can be well documented by comparing the experiences from the partial areas with the data of larger basins and depocenters (facies areas), linked with the part-areas, and country-wide summaries. The comparison was made for two paleogeographic situations: the near-margin overlapping stratigraphic condition and continuous sedimentation in the basin, based on averaged facies thickness data. The aim of the investigation was to determine the vertical facies thickness and the proportions of lateral change and directions, as well as to reveal their correlation possibilities.

It can be seen from the Table 10 that the partial areas correlate well with the facies areas of their own depocenters, and these with the country-wide summaries. The thickness increases basinward in both stratigraphic situations and in different areas; in the basin margin, starting at the outside margin, it increases 1.2-1.5-fold, in the basin 2.5-5.1-fold, and country-wide 5.4-fold. The average would be visibly a proportion of 1:3 but only as a statistical model, since the paleomorphological and basement mobility differences cannot be neglected. In overlapping position, the maximum thickness increase is 5.4-fold as compared to that of the marginal bay. This is influenced decisively by the deep troughs. Extreme thickness occurred in their lower start-of-cycle parts, because the transgression filled them up first with its sediments; the great differences were 
Table 10

Regularities of the Karpatian geologic supercycle in terms of change in facies thickness, paleogeographic position, and investigated area units

\begin{tabular}{|c|c|c|c|c|c|c|}
\hline \multirow{3}{*}{ Paleogeographic position } & \multicolumn{4}{|c|}{ Way of deposition } & \multicolumn{2}{|c|}{ Average thickness } \\
\hline & \multicolumn{2}{|c|}{ Overlapping thickness } & \multicolumn{2}{|c|}{ Continuous thickness } & \multirow{2}{*}{ metre } & \multirow{2}{*}{$\begin{array}{c}\text { growth } \\
\text { ratio }\end{array}$} \\
\hline & $\mathbf{m}$ & growth ratio & $\mathbf{m}$ & growth ratio & & \\
\hline $\begin{array}{l}\text { Outside marginal facies } \\
\text { (Komló Bay) }\end{array}$ & $60 \mathrm{~m}$ & $0 \times$ & $150 \mathrm{~m}$ & $0 \times$ & $89 \mathrm{~m}$ & $0 \times$ \\
\hline $\begin{array}{l}\text { Basin margin } \\
\text { (Zagyva Trough) }\end{array}$ & $92 \mathrm{~m}$ & $1.5 \times$ & $191 \mathrm{~m}$ & $1.2 \times$ & $142 \mathrm{~m}$ & $1.6 \times$ \\
\hline $\begin{array}{l}\text { Basin (depocentre) (Somogy } \\
\text { Trough) }\end{array}$ & $307 \mathrm{~m}$ & $5.1 \times$ & $268 \mathrm{~m}$ & $1.8 \times$ & $249 \mathrm{~m}$ & $2.8 \times$ \\
\hline $\begin{array}{l}\text { Basin (depocentre) (North } \\
\text { Hungarian Trough) }\end{array}$ & $230 \mathrm{~m}$ & $2.5 \times$ & $255 \mathrm{~m}$ & $1.4 \times$ & $180 \mathrm{~m}$ & $1.3 \times$ \\
\hline $\begin{array}{l}\text { Large basins in country-wide } \\
\text { summary }\end{array}$ & $324 \mathrm{~m}$ & $5.4 \times$ & $279 \mathrm{~m}$ & $1.9 \times$ & $264 \mathrm{~m}$ & $3.0 \times$ \\
\hline
\end{tabular}

balanced during the cycle, not least due to facies displacement. The Kiskunhalas-Hódmezốvásárhely-Makó Troughs can be mentioned here as an example. The thickness increase is also significant in the facies areas (depocenters) but it is only $2.5-5.5$-fold. These are mostly similarly deep troughs; however, uplifted horsts and structural zones already dissect the paleomorphological conditions of the basement at the beginning of the cycle. These internal structures create a "nearer-margin" environment, and this is the reason for the relatively great thickness differences. In the table this is represented by the Somogy Trough and the North Hungarian Karpatian sedimentary troughs, with no structural anomalies in the latter that are characteristic in turn of the Drava-MecsekSomogy Trough (Görgeteg-Babócsa Ridge, Inke-Igal Ridge, or for example the "well-like" depression at Kadarkút).

It appears that the basin relief anomalies are buried in every area, due to the advance of the transgression. As a consequence of the facies migration outward from the basin center, the sediment thickness decreases to its half, third, fifth, and finally thins out against the natural coastline. It can be seen from the table that this section already leads to the summary of the faciological regularities, which are only surveyable and definable from the country-wide summaries.

Regularities of the molasse and epicontinental-type sedimentation in the light of the country-wide summaries

The country-wide averaged thickness data of the individual formations (facies), percentage of the margin and basin facies, direction and ratio of change in thickness, and finally the ratio of combined thickness and facies proportions of the two development types served as the basis for evaluation.

On the basis of the data in Table 11 it can be stated that preconditions of synorogenic molasse formation came into being at the beginning and end of sedimentation in the evolution history of the Hungarian Neogene. The "lower 
molasse" corresponds to the time interval of the Early Miocene and Karpatian stages, and to the Savic orogenic cycle and the old Styrian phase of Styrian orogenic cycle. The "upper molasse" began prior to the Pannonian inflexion point of the Late Miocene and developed till the end of the Pontian, possibly continuing into the Pliocene (?) and Quaternary - that is in the closing phase of the Leitha orogenic cycle and during the Rhodanian orogenic cycle. In both molasse cycles, marine and continental molasse can be found in equal measure; the latter is more voluminous, mainly in the upper cycle.

Table 11

Characteristic layer-statistical data of the Hungarian molasse and epicontinental developments

\begin{tabular}{|c|c|c|c|c|c|c|}
\hline Margin facies & $\begin{array}{c}\begin{array}{c}\text { Average } \\
\text { thickness } \\
(\mathrm{m})\end{array} \\
\end{array}$ & $\begin{array}{c}\text { Facies } \\
\text { proportion } \\
(\%)\end{array}$ & Basin facies & $\begin{array}{c}\begin{array}{c}\text { Average } \\
\text { thickness } \\
(\mathrm{m})\end{array} \\
\end{array}$ & $\begin{array}{c}\text { Facies } \\
\text { proportion } \\
(\%)\end{array}$ & $\begin{array}{c}\text { Increase } \\
\text { towards } \\
\text { basin }\end{array}$ \\
\hline \multicolumn{7}{|l|}{ Lower molasse } \\
\hline Pétervására + Budafok & 151 & 29 & Szécsény & 362 & 71 & \\
\hline Szászvár & 316 & 38 & Kettősmező & 513 & 62 & \\
\hline Egyházasgerge & 215 & 43 & Garáb & 279 & 57 & \\
\hline Lower molasse in total & 1,836 & 37 & & & 63 & $1.7 \times$ \\
\hline \multicolumn{7}{|l|}{ Epicontinental } \\
\hline Pécsszabolcs & 104 & 26 & Badenian & 302 & 74 & \\
\hline Rákos & 64 & 36 & Szilágy & 116 & 64 & \\
\hline Tinnye & 52 & 20 & Kozárd & 213 & 80 & \\
\hline Tótkomlós & 52 & 20 & Endröd & 213 & 80 & \\
\hline Epicontinental in total & 1,116 & 24 & & & 76 & $3.0 \times$ \\
\hline Algyö & 300 & 39 & $\begin{array}{c}\text { Szolnok }+ \\
\text { Algyö }\end{array}$ & 478 & 61 & \\
\hline Zagyva & 491 & 31 & $\begin{array}{c}\text { Újfalu }+ \\
\text { Zagyva }\end{array}$ & 1,087 & 69 & \\
\hline Upper molasse in total & 2,356 & 34 & & & 66 & $2.0 \times$ \\
\hline $\begin{array}{l}\text { Molasse development } \\
\text { in total }\end{array}$ & 1,473 & 35 & & 2,719 & 65 & $1.8 \times$ \\
\hline $\begin{array}{l}\text { Epicontinental } \\
\text { development in total }\end{array}$ & 272 & 24 & & 844 & 76 & $3.0 \times$ \\
\hline $\begin{array}{l}\text { Hungarian Neogene in } \\
\text { total }\end{array}$ & 1,745 & 33 & & 3563 & 67 & $2.0 \times$ \\
\hline
\end{tabular}

In the middle of the Neogene supercycle (corresponding to the time of major marine transgressions), postorogenic epicontinental-type sedimentation took place. It lasted from the beginning of the Lower Badenian approximately to the inflexion point of the Pannonian; that is, it was the prevailing sedimentation type in the new Styrian phase of the Styrian orogenic cycle, and a predominant part of the Leitha orogenic cycle. This sedimentation was also variegated in a characteristic way by repeated volcanic activity (perhaps of island arc-type).

A characteristic feature of the molasse sedimentation, representing $78 \%$ of the Hungarian Neogene, is the marginal facies proportion between $29-43 \%$ and 
basin faciesal proportion of $57-71 \%$. In the epicontinental development, $20-36 \%$ is the proportion of marginal facies and $64-80 \%$ (that is, higher) that of basinal facies. In the latter the postorogenic character is also reflected in the thickness ratio: the thickness decreases to one-third toward the margin, and only approximately to half in the case of synorogenic molasse. The synorogenic nature of the molasse is also proved by the thicker zones of lateral facies interfingering; they show great scattering in different facies areas, and make up $30-50 \%$ of the total thickness of molasse series. In the total thickness of epicontinental series, the interfingerings appear with smaller (between 41-45\%) scattering; in accordance with the postorogenic character and the already balanced paleomorphological conditions even the zone width of interfingering is smaller. This is also due to the fact that the average width of the 5 facies belts, calculated for the molasse basin (without the Pontian), is $59.4 \mathrm{~km}$, corresponding to an average of $25.6 \mathrm{~km}$ in the epicontinental basin for 6 facies belts, that is, less than half.

In summary it can be stated that characteristic features of the lower and upper molasse correlate well with each other; $34-37 \%$ is the proportion of marginal facies and $63-66 \%$ is that of basinal facies. In the epicontinental development, the thickness proportion of marginal facies is $24 \%$ (that is, less) and $76 \%$ (that is, more) of basinal facies. All these prove the extreme intensity, cyclicity, and high energy level (current conditions) of the Savic and Early Styrian orogenic cycles and late Leitha phases. The new Styrian and early Leitha phases resulted in more balanced sedimentation, though under more varied basement morphological and margin structural conditions.

\section{Results of investigations of reefal developments and their heteropic facies}

In the vertical geologic structure of the Hungarian Neogene, reef formations are frequent and widely distributed. In general, they are mostly carbonate reef bodies, created by classic reef-building organisms. In addition, calcarenites, composed of predominantly lumachelle beds of calcareous organisms or ground shell remnants, containing a varying amount of siliciclastic debris as well, have been also evaluated. Our basic criteria were the calcareous matrix, the type of bedding, and especially the stratigraphic position of the formed rock body and its determinant paleoenvironmental-paleomorphologic role. We have also taken into account the periodically constructive-destructive bay closing sand banks, sandstone lenses, and gravel-conglomerate barriers, although we have generally neglected them in the calculations, even if part or all of them corresponded to one of the above criteria.

Reef bodies can be excellently fitted into the lithostratigraphic system at the level of formations, members, or layers; they are limited in time and space and usually well delimitable. In the heteropic facies, developed between the reefs in lagoons, forelands, in near-shore or off-shore open but generally shallow water, predominantly pelitic series were deposited. Their vertical and lateral contact 
provides classic examples of multiple interfingering of coeval facies in space and time.

The significance of the investigation of the reef formations is emphasized by the great opportunity to reconstruct the living and inanimate environment, and the creation of the scientific basis of environmental protection, raw material exploration and extraction prognoses.

\section{Reef developments in the Hungarian Neogene sequence}

During the Early Miocene, in addition to the sedimentation conditions of predominantly molasse nature, reef bodies came into being, but only under especially favorable conditions, for a shorter period of time, and then only locally. In Hungary, examples are the larger Foraminifera-Lithothamnium-bearing, thinbedded limestone shoals of the Upper Egerian Csókás Formation, and the Miogypsina-bearing corallinacean coastal reefs that can be identified with the Bretka Formation of uncertain age in the southwestern margin of the AggtelekRudabánya Mts.

At the beginning of the Middle Miocene Karpatian sedimentary cycle, Congeria limestone and calcareous limestone reefs were formed in Western Hungary (Pécsvárad Member of the Budafa Formation) that were repeated locally at the end of the cycle. In Northern Hungary, the end-of-cycle Fót Formation contains reefs composed of longshore Pecten-lumachelle banks and Ostrea banks.

Due to their features and the lack of substantial exposures and knowledge, the Early Miocene and Middle Miocene initial reefs cannot be evaluated from a layerstatistical standpoint.

Mediterranean-subtropical reefs of regional distribution were first developed in Hungary during the Lower Badenian. These "Lower Leitha Limestone" reefs (Pécsszabolcs Formation) came into being mainly in the Western Hungarian areas, connected to the Styrian type areas. Beginning with thick-bedded, coarse abrasion debris, they are characterized by frequently sandy, mollusk-bearing, coarse limestone and Lithothamnium limestone with sandstone intercalations. Later the Sámsonháza Formation and Abony Formation became known as accepted synonyms in northeastern and eastern Hungary. The former is characterized by thin lava layers and hydropyroclastics deposited between longshore biogenic reef limestone and shallow-water micaceous, fine-grained sandy pelites. In the Abony Formation breccia, conglomerate, and sandstone formations of varying grain size, cemented with carbonate, alternating with thick-bedded volcanosediments as well as sandy limestone banks and lenses, situated randomly, and containing lumachelle banks of thick-shelled mollusks, are predominant.

Data of the layer-statistical investigations of the "Lower Leitha Limestone" are presented by formations and in country-wide summary in the first part of Table 12. 


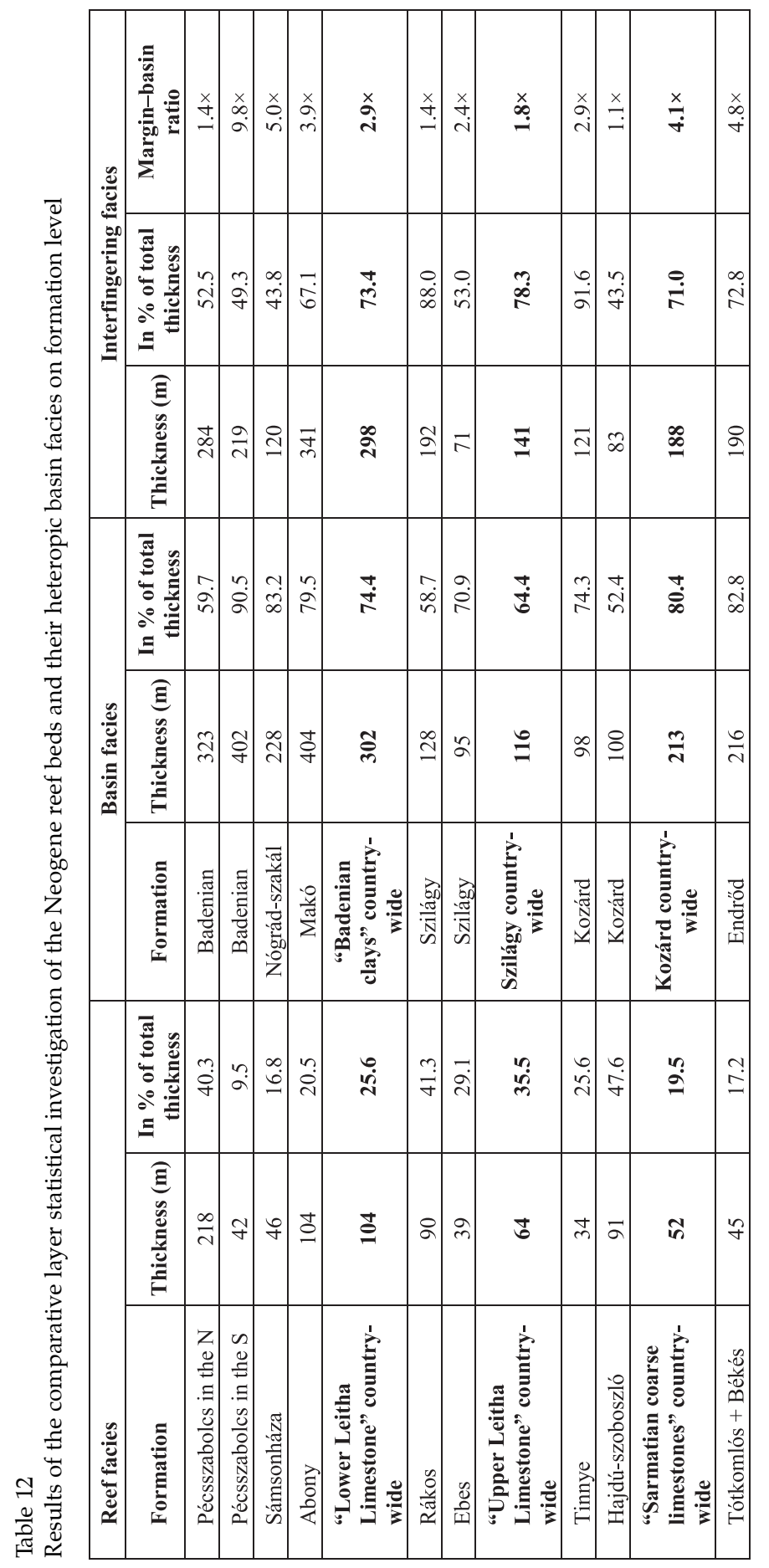


It is remarkable that during the Middle Badenian (the closing regressive phase of the Middle Miocene sedimentary cycle) no reefs came into being in spite of the overall decrease in water level. This can be explained by the increasing fresh water influx due to hinterland elevation and the accompanying increase in the amount of debris transport and the subsequent change in light penetration and temperature conditions of water. After the uplift, bog formation and volcanic paroxysm, however, the repeated Late Miocene transgressions created a new situation due to the Leitha orogenic cycle.

During the Upper Badenian, "archipelago"-type environments of great extent came into being in the area of simultaneously intensely subsiding, larger basins. Within them, extensive but thin reef plateaux were developed, characteristically from algal mats and very frequently encrusting the rocky substrate; they can be found in shallower and warmer water, under euphotic conditions. At their margins, mollusk-bearing coarse limestone connected to the reef top, and on the reef slope calcarenites of varying grain size and thickness, are deposited. The Lithothamnium limestone and marl thin out toward the lagoons with calmer water, shallow water bays, and smaller marine basins, or interfinger with the pelitic formations of basinal facies (Szilágy Clay Marl Formation). The Upper Badenian reefs, the so-called "Upper Leitha Limestone", are represented predominantly by the Rákos Limestone Formation in Western Hungary and the Ebes Formation (as a synonym in Eastern Hungary, without the possibility of exact correlation).

The areal distribution of the reef facies - with a local regression during the Sarmatian and a smaller transgressive invasion again at the beginning of the Pannonian - is unchanged during the Late Miocene, but has a significantly different structural position as compared to the previous ones. The areal distribution of the Sarmatian reef facies roughly follows the area of the Upper Badenian reef plateaux. The facies is represented by the Tinnye Formation in the west and the Hajdúszoboszló Formation as a synonym in the east (with no possibility of delimitation). Both of them are characterized by mollusk-bearing coarse limestone, Cerithium limestone, and "granulous (ooidal) limestone", as well as bryozoan-bearing limestone developments. At the reef boundaries, transition and interfingerings of the calcareous-sandy and calcareous-marly margin with the pelitic formations of basin facies can be observed (Kozárd Clay Marl Formation). During the Pannonian, these reefs mostly developed further in the beds of the Tótkomlós Formation (in other words the Tótkomlós Member of the Endród Marl Formation). The authigenetic breccia reefs of nearly the same average thickness, calcareous marl and carbonate material are completed with the coarse clastic gravel patches of carbonate matrix of the Békés Conglomerate (previously mentioned separately as Mihályi Conglomerate) in the paleomorphologically more dissected areas. Due to rapid basement subsidence, the fauna of these formations is poorish; the reef formation was soon drowned and replaced, both in time and space, by the Endrőd Marl Formation. 
Data of the layer-statistical investigations of the Late Miocene reef beds are presented by formation and in a country-wide summary in the second part of Table 12 .

An extraordinarily important circumstance is that a characteristic form of the Late Miocene reefs is the reef plateau, developed on the erosional, at some places abrasional, terrain of the margins of uplifted mountain parts. Another characteristic form is a several $\mathrm{km}$-long reef series, thickening zonally and deposited as a "cap" on linear paleomorphological ridges and block series in the mobile zones above the contact of the buried tectonic units. The relevant numerical data are documented by the summary data of Table 14 .

The data of the table confirm the picture that during the Middle Miocene-Late Miocene:

- the thickness of the reef facies decreased continuously, approximately to half, from $100 \mathrm{~m}$ to $45 \mathrm{~m}$. During the Badenian, it amounted to more than one-third of the sequence - that is, it had increased up to that time - and during the Sarmatian-Pannonian decreased to one-fifth;

- the mass proportion of the basinal facies appeared at the same time, but inversely: during the Lower Badenian it made up three-quarters of the sequence, but during the Upper Badenian only two-thirds - that is, it showed a decreasing trend - and during the Sarmatian-Pannonian it increased gradually to four-fifths;

- the average lateral thickness change of the two large facies units follows and supports the trend above: in basinal direction it is nearly threefold, then decreases to twofold during the Lower Badenian-Upper Badenian. During the Sarmatian-Pannonian, it increases almost to fivefold;

- the degree of interfingering of the two large facies units is $73.4 \%$ in average during the Lower Badenian, increases to $78.3 \%$ in average during the Upper Badenian, then decreases to 70.9-72.8\% during the Sarmatian-Pannonian.

In summary it can be stated that regularities, parallel in time, characterize the proportion of the mass ratio of the reef facies and the degree of lateral interfingering. At the same time, the change in the mass ratio of the basinal facies in the sequence and the ratio of lateral thickness change of marginal - basinal facies appears in spatially inverse proportions, but also in parallel. All these confirm the tectogenetic-paleogeographic interpretation that the Middle Miocene series came into being in structurally preformed (deep) troughs, in a relatively narrow basin space with less structural elements and relatively homogeneous paleorelief. This appeared with vertically rapid and laterally pronounced facies changes.

The Upper Miocene series were formed at the beginning of the Leitha orogenic cycle in the area of practically simultaneously intensely subsiding larger structural units, namely flat (dish-shaped) basins. They were dissected by structural elements, causing more (but small-scale) displacements than the previous ones and creating paleorelief conditions, also diversified by the volcanic edifices. The vertical and lateral facies changes are gradual and develop continuously in a 
lateral direction. This is the typical archipelago environment that also determines the paleoenvironment of the repeated Sarmatian to Early Pannonian marine transgressions from the beginning of the Upper Badenian transgression.

During the next phase of the orogenic cycle (in the Middle Pannonian), the hinterland elevation and simultaneous basin basement subsidence accelerated gradually, due to structural inversion. As a combined result of the SarmatianEarly Pannonian transgressions, occurring in rapid succession further on, and the increasing debris transport from the hinterland, the mass ratios shifted in favor of basinal sediments. The process is closed by the Late Pannonian-Pontian delta progradation, as a consequence of the still increasing hinterland elevation.

\section{Problems of the "Lower" and "Upper Leitha Limestone"}

Concerning the Neogene reef formations, the greatest amount of geologic mapping and stratigraphic debates were aroused by the so-called Leitha limestone. It is difficult to understand why this should be, especially since the earlier, very knowledgeable predecessors working in this area also recognized their separate appearance as two horizons in several facies areas of the Carpathian Basin. In the present-day area of Hungary and the adjacent territories, Peters (1861), Böckh (1876), and Vadász (1914) published the definite existence of two Leitha limestone horizons from the Mecsek Mts; Schafarzik (1892), Noszky $(1912,1931)$ and Strausz $(1923,1929)$ did the same for the Cserhát Mts. Hámor $(1970,1985)$ was able to support their conclusions thanks to availability of core material in both areas.

The reason for the repeated efforts, up to the present, to create a single, merged "Leitha Limestone" horizon, is that the collection, interpretation, and evaluation of the necessary macro- and microfauna are extremely time and laborconsuming, due to the practically totally similar facies and hard reef formation lithology. As a consequence thereof the greatest success of biostratigraphy-based age determination so far is the registration of the level of Badenian stage; the formation-level evaluation has not been completed up to the present. An interesting contradiction, however, is that the basin sediments of the Badenian series can be excellently subdivided by several paleontological methods. This is why the notion that continuous Leitha Limestone formation took place on the margins in the ideal model during the Badenian is widespread. This model could never be proved in the natural environment. It would be a serious mistake and a significant step back in geologic knowledge to amalgamate again the Leitha limestones under name "Leitha Limestone Formation" unwarrantedly totally disregarding the Hungarian lithostratigraphic system - and neglecting the chronostratigraphic system of the Badenian stage, established as the result of wide-ranging international co-operation. This nonsense is further enhanced by the simultaneous intention to assign the Lower Leitha Limestone into a Badenian-1 as the Pécsszabolcs Limestone Member and the Upper Leitha 
Limestone into a Badenian-2 as the Rákos Limestone Member (Gyalog and Budai 2004).

Below the distinguishing features of the two Leitha limestone formations are presented again,on the basis of the results of the layer-statistical and formationstatistical investigations. The comparative investigations focused on the compilation of the database hinterland of the formations, their petrographic composition, deposition and thickness conditions, heteropic facies, footwallhanging wall conditions, the calibrated 3D distribution of the rock body, detection of the regional differences, and their documentative interpretation. For this work an outstanding hinterland area was provided by the paleogeographic reconstruction of the Neogene of the Carpathian Basin (Hámor 2001a) and the recognition of the basically new tectonic system of the Pannonian Basin (Hámor et al. 2001; Hámor 2001b, 2002).

\section{Characterization of the "Lower" and "Upper Leitha Limestone"}

The layer-statistical evaluation of the two Leitha limestone units presents the similar and different lithological features of the formations (Table 13).

Table 13

Layer-statistical investigation of the petrographic composition of the "Lower" and "Upper Leitha Limestone", using the example of the Nógrád-Cserhát type area

\begin{tabular}{|l|c|c|}
\hline & $\begin{array}{c}\text { "Lower Leitha Limestone" } \\
\text { (Sámsonháza Fm.) (\%) }\end{array}$ & $\begin{array}{c}\text { "Upper Leitha Limestone" } \\
\text { (Rákos Fm.) (\%) }\end{array}$ \\
\hline Gravel & 3.7 & 8.4 \\
\hline Sand & 53.9 & 69.4 \\
\hline Pelite & 28.0 & 7.5 \\
\hline Limestone (including calcarenite) & 14.4 & 14.7 \\
\hline Total & $\mathbf{1 0 0 . 0}$ & $\mathbf{1 0 0 . 0}$ \\
\hline
\end{tabular}

In the comparison, the proportions of gravel content are justified by two factors: the footwall of the Sámsonháza Formation is in every instance an older Miocene formation (in this particular area the schlier complex of Karpatian age) and the small amount of gravel material derives from the Early Miocene continental formations of the more distant regions. The two to three-fold higher gravel content of the Rákos Formation is due to the fact that the complex is deposited on the pre-Tertiary basement in an unconformably overlapping fashion, with abrasional basal gravel (boring clam traces) in larger areas. The same phenomenon is reflected by the difference in the sand content, together with the facts that part of the sand material is of andesitic origin and that the footwall derives from the Mátra Andesite Formation. The nearly four-fold proportion of the pelitic layers in the "Lower Leitha Limestone" reflects that interfingering is more frequent with the heteropic facies of the formation within the basin, in the given case the Nógrádszakál Marl Formation, based on the 
character of the continuously advancing Middle Miocene transgression. In turn, the "Upper Leitha Limestone" is a reef plateau, developed as a result of rapid subsidence, that interfingers less with the pelitic sediments of the intermediate lagoons and more with open-marine basinal parts (Szilágy Clay Marl Formation). The transition, limited to a narrow zone, is instead represented by calcarenite (e.g. Ditrupa-bearing calcareous sandstone) or Lithothamnium-bearing marl. The strikingly identical proportion of limestone facies is a result of approximately identical paleoenvironmental and paleoclimatic conditions; their molluskbearing coarse limestone, Lithothamnium-bearing limestone, and calcarenite fall under the same evaluation from the layer-statistical point of view. Their more detailed investigation cannot be statistically evaluated, due to random deposition, thickness changes and transitions. However, it is documented in a country-wide study that the Lower Leitha Limestone is mainly characterized by thick-bedded, hard limestone, and the upper one by thin-bedded, more unconsolidated calcarenite and Lithothamnium-bearing hardgrounds and encrustations.

\section{General geologic aspects of distinguishing the two Leitha limestone horizons}

Structural control and tectonic setting

The structural frameworks of the Lower Badenian correspond to those developed during the Middle Miocene Karpatian. At the margins of the basin, the extent boundaries of the two stages are practically the same; the different facies belts are situated above each other. Subsequently, overlapping of the Lower Leitha Limestone onto the substrate is rare; it may amount to a maximum of 4-5\% in frequency percentage. Ingressive-type substrate overlapping of the beds of the Badenian Clay Formation, appearing as a heteropic facies, has an even lower rate.

Following the volcanic paroxysm of the Carpathian Basin, the "Upper Leitha Limestone" was deposited in a totally different structural system, overlapping onto the substrate to an extreme degree. The system also survived during the Sarmatian and Early Pannonian. The degree of marginal overlapping decreases but can be revealed by statistical frequency methods. The structural system of the two Leitha limestone horizons appears one above the other, shifted by about $90^{\circ}$.

\section{Stratigraphic situation}

Thus, the Lower Leitha Limestone was deposited predominantly on the sedimentary beds of the Egyházasgerge, Garáb and Fót Formations of Karpatian age, rarely on the Hasznos Andesite and Tar Dacite Tuff Formations; locally deposition occurred with smaller angular unconformity. Its stratigraphic cover is the Hidas Lignite or the Mátra Andesite Formations. Its interfingering heteropic sedimentary facies is the Nógrádszakál Marl Formation, elsewhere exclusively the Badenian Clay Formation. which is frequently its natural cover as well, due 
to the facies migration of the transgressive cycle. More rarely, to a slight degree the cover could be the initial hydropyroclastics of the Middle Badenian volcanic formations. As a result, the Lagenida and Spiroplectammina foraminifer zones, as well as the nannozone NN5 appear in the formation, and its heteropic facies in the microfaunistic zonation. Its interfingering with zones NN4 or NN6 cannot be demonstrated in spite of several thousand studied samples.

The "Upper Leitha Limestone" is deposited on the pre-Neogene substrate, above the Early Miocene or Middle Miocene sedimentary series; furthermore regularly over the Middle Badenian Mátra Andesite Formation in various ways, consistently with hiatus or angular unconformity, and a frequency of about equally $70-80 \%$ according to the vertical and lateral statistical data (Table 14). Owing to the facies migration of the transgression cycle, its cover is the Szilágy Clay Marl Formation, or in lacunar marginal sequences the Tinnye Formation and its synonyms. The "Upper Leitha Limestone" appears interfingered with the Szilágy Clay Marl Formation. Its age is determined by the Bulimina-Bolivina (BulBol) benthonic foraminifer zone as well as the NN6 nannoplankton zone that can be proved only in traces.

Theses supporting the separation of the two Leitha limestone horizons

a) A microfauna-based biostratigraphic subdivision of the two Leitha limestone horizons can hardly be made. Some aspects are provided by the collective taxon number of the two formations, that is, the number of taxa appearing only in one or the other formation, and the number of common (cosmopolitan) taxa that are present everywhere. These data were published by Hámor $(1970,1985)$ on the basis of the statistical and frequency evaluation of the published material from the collections from the Mecsek and Cserhát Mts back to the 19th century. Further frequency, extension, facies connection, numerical, and percentage data of the Lower and Upper Leitha Limestone formations (in some cases comparing them with the data of their heteropic basinal facies, and similarly younger reefal formations) are shown in Table 14. The certainty of its classification is documented in Table 15 on the basis of depositional and stratigraphic data from 255 sections.

b) Both limestone horizons could be detected in the same section above each other in 21 facies areas. Among them 16 areas can be found in Western Hungary and 5 in Eastern Hungary.

c) The stratigraphic position of the two Leitha limestone horizons is emphasized by the fact that the "Lower Leitha Limestone" is deposited almost exclusively on Karpatian formations. Compared to the Karpatian formations, the lateral areal overlapping of the "Lower Leitha Limestone" is only $2.2 \%$; the "Upper Leitha Limestone" is deposited directly on substrate in $87.3 \%$ of the boreholes that reached the Upper Badenian. Those remaining, only $12.7 \%$, show that not more than 25 boreholes encountered the Szilágy Clay Marl Formation (of 
Table 14

Results of the comparative layer-statistical investigation of the "Lower Leitha Limestone" and "Upper Leitha Limestone" (Pécsszabolcs Formation and Rákos Formation with their synonyms) in a countrywide overview

\begin{tabular}{|c|c|c|c|}
\hline Badenian formations & $\begin{array}{c}\text { Out of them } \\
\text { Lower Badenian in } \\
\text { total: }\end{array}$ & $\begin{array}{c}\text { Out of them } \\
\text { Upper Badenian in } \\
\text { total: }\end{array}$ & Remarks \\
\hline $\begin{array}{l}\text { Linear metre of boreholes, exploring } \\
\text { series of Badenian age in total: } 46,659 \\
\mathrm{~m}=100 \%\end{array}$ & $23,866 \mathrm{~m}=51.2 \%$ & $22,773 \mathrm{~m}=48.8 \%$ & Nearly the same \\
\hline $\begin{array}{l}\text { Number of boreholes, exploring series } \\
\text { of Badenian age: } 400 \mathrm{pcs}=100 \%\end{array}$ & $148 \mathrm{pcs}=37 \%$ & $252 \mathrm{pcs}=63 \%$ & $1.7 \times$ more frequent \\
\hline $\begin{array}{l}\text { With overlapping position out of the } \\
\text { above: } 181 \text { pcs }=45.2 \%\end{array}$ & $38 \mathrm{pcs}=21.0 \%$ & $143 \mathrm{pcs}=79 \%$ & $4 \times$ more frequent \\
\hline $\begin{array}{l}\text { Proportion of boreholes, reaching reef } \\
\text { formations }\end{array}$ & $\begin{array}{l}\text { "Lower Leitha } \\
\text { Limestone" } \\
\text { 148:38 }=25.6 \%\end{array}$ & $\begin{array}{l}\text { "Upper Leitha } \\
\text { Limestone" } \\
252: 143=56.7 \%\end{array}$ & $2.2 \times$ more frequent \\
\hline $\begin{array}{l}\text { Lateral extension of Badenian reef } \\
\text { formations throughout the country: } \\
2,755 \mathrm{~km}=100 \%\end{array}$ & $560 \mathrm{~km}=20.3 \%$ & $2,195 \mathrm{~km}=79.6 \%$ & $4 \times$ more frequent \\
\hline $\begin{array}{l}\text { Their areal extension, calculated from } \\
\text { the above data, within the } \\
\text { stratigraphic unit }\end{array}$ & $25.6 \%$ & $35.5 \%$ & $1.4 \times$ more frequent \\
\hline $\begin{array}{l}\text { Areal extension of their equivalents of } \\
\text { basin facies within the stratigraphic } \\
\text { unit }\end{array}$ & $74.4 \%$ & $64.4 \%$ & $\begin{array}{l}\text { The latter one is } \\
\text { smaller by } 10 \%\end{array}$ \\
\hline \multicolumn{4}{|c|}{ Measuring } \\
\hline $\begin{array}{l}\text { Average thickness in overlapping } \\
\text { position }\end{array}$ & $178 \mathrm{~m}$ & $80 \mathrm{~m}$ & $\begin{array}{l}\text { The latter one is } \\
\text { thinner by } 45 \%\end{array}$ \\
\hline $\begin{array}{l}\text { Average thickness in continuous } \\
\text { sedimentary sequence }\end{array}$ & $192 \mathrm{~m}$ & $116 \mathrm{~m}$ & $\begin{array}{l}\text { The latter one is } \\
\text { thinner by } 40 \%\end{array}$ \\
\hline $\begin{array}{l}\text { Proportion of interfingering of reef } \\
\text { and basin facies (in \% of the average } \\
\text { thickness) }\end{array}$ & $73.3 \%$ & $78.3 \%$ & Nearly the same \\
\hline Average width of reef facies $(\mathrm{km})$ & $18.6 \mathrm{~km}=40.4 \%$ & $27.4 \mathrm{~km}=56.4 \%$ & $\begin{array}{l}\text { The latter one is } \\
\text { wider by } 16 \%\end{array}$ \\
\hline Average length of reef facies $(\mathrm{km})$ & $80 \mathrm{~km}=26.6 \%$ & $220 \mathrm{~km}=73.3 \%$ & $\begin{array}{l}\text { The latter one is } \\
\text { longer by } 47 \%\end{array}$ \\
\hline
\end{tabular}

ingressive character), deposited directly on the substrate. "Upper Leitha Limestone" is deposited on Lower Badenian or older sequences in only $11.8 \%$ of the boreholes that encountered the total Badenian sequences, and even there mostly with demonstrated unconformity.

d) It should also be taken seriously into account that in the areas where both Leitha limestone units can be found in the same section (see Table 14), the 30-120 $\mathrm{m}$-thick Hidas Lignite Formation (in places with totally freshwater or even fluvial intercalations) or the similarly extended and in this stratigraphic situation 400-800 m-thick Mátra Andesite Formation is deposited between them. The 21 areas presented in the table include nearly one hundred boreholes, 25 alone in the southern part of the Hidas lignite area. 
Table 15

Certainty of the stratigraphic evaluation of the two Leitha limestone horizons on the basis of the formation-statistical investigations of the stratigraphic situation and footwall-hanging wall conditions

\begin{tabular}{|l|c|c|c|}
\hline Sections & $\begin{array}{c}\text { "Lower Leitha } \\
\text { Limestone" }\end{array}$ & $\begin{array}{c}\text { "Upper Leitha } \\
\text { Limestone" }\end{array}$ & Remarks \\
\hline $\begin{array}{l}\text { Number of sections, } \\
\text { investigated specially from } \\
\text { stratigraphic point of view } \\
\text { Total: } 255 \text { pcs }\end{array}$ & $133 \mathrm{pcs}=52.2 \%$ & $122 \mathrm{pcs}=47.8 \%$ & Nearly the same \\
\hline $\begin{array}{l}\text { Deposited on substratum out of } \\
\text { the above }\end{array}$ & $6 \mathrm{pcs}=4.5 \%$ & $26 \mathrm{pcs}=18.8 \%$ & $4 \times$ more \\
\hline $\begin{array}{l}\text { With stratified footwall and } \\
\text { hanging wall out of the above }\end{array}$ & $40 \mathrm{pcs}=30.0 \%$ & $49 \mathrm{pcs}=40.2 \%$ & More by $10 \%$ \\
\hline $\begin{array}{l}\text { Stratified only with footwall or } \\
\text { hanging wall }\end{array}$ & $64 \mathrm{pcs}=48.1 \%$ & $45 \mathrm{pcs}=36.8 \%$ & Less by $12 \%$ \\
\hline $\begin{array}{l}\text { Section of uncertain } \\
\text { classification in total }\end{array}$ & $23 \mathrm{pcs}=17.4 \%$ & $5 \mathrm{pcs}=4.2 \%$ & Insignificant \\
\hline $\begin{array}{l}\text { Section of certain classification } \\
\text { in total }\end{array}$ & $110 \mathrm{pcs}=82.6 \%$ & $117 \mathrm{pcs}=95.8 \%$ & Satisfactory \\
\hline Drilling sections in total & $133 \mathrm{pcs}=100 \%$ & $122 \mathrm{pcs}=100 \%$ & \\
\hline
\end{tabular}

e) Both extent and facies areas of the two Leitha limestone horizons are different. "Lower Leitha Limestone" is more frequent and thicker in the west, due to the transgression from the SW; it becomes rarer and thinner (from 200 to $50 \mathrm{~m}$ ) northeastward, and finally pinches out, approximately in the region of the Tarna Line.

The transgression of the "Upper Leitha Limestone" came from the SE and was developed in its greatest thickness in a northwesterly direction at the mountain margins; however it thins out (from 400 to $90 \mathrm{~m}$ ) northeastward.

This picture is also supported by the frequency-statistical data of areal overlapping; the lower Leitha limestone is more frequent in the $\mathrm{W}$ and the upper one in the E: this is proved equally by the statistics of the vertical system as well as those of the lateral one.

New results of the delimitation of the reef bodies

An extremely important observation, and a new result, is that only part of the reefs are developed in linear fashion, directly along the shoreline of continent. Frequently, the reefal facies develops on morphologically elevated parts of the basin basement. It forms upon its smaller blocks, cliff peaks, or the reefal beginnings of clastic banks, formed in the swash zone (and occasionally composed of mollusk lumachelle). However, the landward boundary of the real reefs can be identified, based upon the following considerations.

From the Karpatian to the beginning of the Pannonian, reef formations came into being as a consequence of continuous transgressive cycles. During the 
repeated, intensifying cycle or its most intense phase, possibly a storm tide, the belt of the basinal facies shifted toward landward. Walter's facies law is effectively demonstrated here; formations immediately adjacent to each other in time become each other's cover. For this reason, and at this time, a situation may arise in which sediments of the "overrunning" transgression are deposited in an ingressive way on the substrate of the surroundings - without basal formations and in a narrow zone. Perfect examples of this are the sand reefs of the coastal bars at the base of the Karpatian, behind which, in the protected lagoons, microbedded formations were deposited with a frequency in harmony with the monsoonal season (see section above "Case studies on detailed quantitative evaluation..."). In the case of the "Lower Leitha Limestone" reefs, this is proved by the thin layers of ingressive deposition of the Badenian Clay Formation; in the case of the "Upper Leitha Limestone" by similar-type layers of the Szilágy Clay Marl Formation that can be characterized as sediments of a diatomaceous inner lagoon, and on the top part of the Tinnye Formation by spectacular storm tide structures. At the same time, bryozoan meadows (Tétény Plateau, Budapest; petrified in upright position), ooidal sand, Hydrobia-bearing marl, as well as diatomaceous formations, already assignable to the Kozárd Formation, can be detected at the back of the reefs.

Evaporites (gypsum-anhydrite, native sulphur) of the Budajenő Formation were formed in a special drying out back-reef lagoon; they are always covered by the Kozárd Formation, which becomes predominant. Their near-land formation, and the occasionally ingressing marine water (which then evaporated), are proved by the coeval evaporite traces that can be detected in the smaller intramontane local basins of the Bakony and Cserhát Mts (Gyulafirátót Formation, Ős Variegated Clay Formation, Sajóvölgy Formation).

The enumeration of the series of the analogous formations can be continued with the "ostracodal white marls", formed in Early Pannonian back-levee facies, as well as thinly laminated authigenetic breccia, composed of fragments of desiccated calcareous marl (southern margin of Eastern Mecsek Mts, Fruška Gora Mts-Beocin, Medvednica).

Delimitation of the lateral extent on the basis of frequency of the extension of carbonate facies is also possible basinward. On the basis of these new perceptions the evaluation, qualification, and classification of these rock bodies, occasionally debatable but corresponding to the "reef" concept from every point of view, became justified and proved.

On the basis of the above perceptions the delimitation of the reef belts can be modeled equally well toward dry land or open water.

\section{Reef dimensions}

In addition to the possibility of distinguishing the two Leitha limestone horizons, the layer-statistical investigation permitted the determination of reef 
Table 16

Dimensions of the Hungarian Neogene reef formations on the basis of country-wide averages

\begin{tabular}{|l|c|c|c|}
\hline Contiguous reef bodies & $\begin{array}{c}\text { Average reef width } \\
(\mathbf{k m})\end{array}$ & $\begin{array}{c}\text { Average reef length } \\
(\mathbf{k m})\end{array}$ & Extension $\left(\mathbf{k m}^{2}\right)$ \\
\hline "Lower Leitha Limestone" & 18 & 80 & 1,440 \\
\hline $\begin{array}{l}\text { "Upper Leitha Limestone" }+ \\
\text { Sarmatian coarse limestone }\end{array}$ & 28 & 220 & 6,160 \\
\hline $\begin{array}{l}\text { Early Pannonian formations of } \\
\text { reef character }\end{array}$ & 14 & 50 & 700 \\
\hline
\end{tabular}

dimensions, which is important from a practical point of view. Characteristic data of the results of the investigation can be seen in Table 16.

Therefore, compared to the Lower Badenian reef dimensions, the Upper Badenian-Sarmatian reef bodies show a fourfold extent; during the Pannonian this decreases to less than its eighth.

\section{Structural differences}

The separation of the two Leitha limestone horizons is equally confirmed by the structural data of the observed structural elements and the edited sections. Frequently, the "Lower Leitha Limestone" appears in typically folded structural systems. During the compressive phase of the Leitha orogenic cycle, the Neogene occurs in disharmonically folded forms in preferred structural zones, due to spatial shortening. Because of their dimensions, as well as the degree to which they have been explored, the often repeated anticline-syncline forms are known mainly in Transdanubia: e.g. in the Zala-Drava Basin, around NagyatádKadarkút in South Somogy, in the northwestern foreland of the E Mecsek Mts (classically around Hidas), as well as in the southern foreland of the mountains. The axial directions of these folded structures differ characteristically from the measurable elements of the previous and the younger structural effects. Rarely some meter-thick folded forms can also be found in the Lower Leitha Limestone (Hámor 1970). The "folded domes" of older literature turned out to be Upper Badenian-Sarmatian reefs, formed on the elevated blocks of the substrate, which really are "deposited domes" and may affect the interpretation of older vintage seismic sections. Their examples are known from the Inke-Igal block series in Somogy, or in the surroundings of the Mihályi Ridge in the Little Plain.

The Upper Leitha Limestone and the Sarmatian reefs, developed together organically, are characterized by unfolded tabular fault structure. Their type areas can be found on the Tétény Plateau, in the neighborhood of Tapolca, in Hajdúság. Their structural elements, developed mostly in the Rhodanian cycle, can be regarded as the rejuvenation of the old structural lines of the substrate. As a consequence, reverse fault "schuppen structures" can also be found on the margins of the tabular structure, in which Paleo-Mesozoic rock bodies were thrust over the Late Miocene reefs (in the zone of the Mecsekalja Line, Bugac, and the Hajdúság Lineament). Due to their different extension, such structures are not known in connection with the Lower Leitha Limestone. The Pannonian- 
Pontian series, deposited as the cover of the Upper Badenian-Sarmatian, show wide, flattened synclinal forms in the large basins - unlike their footwall. Their structural geologic interpretation can be viewed as a basin formation-basement subsidence-upfilling mechanism, taking into account the compaction of several thousand meter-thick series; it seems that the row of disharmonically folded forms were formed here as well, due to the two larger structural event ranges of the Late Miocene, but in a different order of magnitude.

\section{Layer-statistical data}

The separation of the two Leitha limestone horizons is definitely proved by the layer-statistical data. The reliability of the method is provided by the huge amount of data, as well as the fact that both units are supported by an equivalent amount of information (linear meters of borehole drilling, number of boreholes by formation facies, stratigraphic position, and all this in vertical and lateral comparison). The reliability of the evaluation is underscored, for example, by the extremely consistent data of the lateral distribution of the Leitha limestone units of overlapping position and the Badenian reef formations - in spite of the different approach (see Table 14). According to both systems the occurrence of the Upper Leitha Limestone is four times more frequent. The nearly identical basic aspects of stratigraphic evaluation (number of sections, degree of exploration, footwall-hanging wall conditions, etc.), as well as the very close reliability indices (83\% and 96\%, rounded upward) are also in harmony with the data on frequency, and confirm the chronostratigraphic classification.

The picture of thickness changes is also variable but characteristic in consequence. For both the Lower and Upper Leitha limestone, their average country-wide thickness, average thickness in overlapping deposition, and average thickness in continuous sedimentary sequence show equally a decrease of nearly $50 \%$ of the Upper Leitha limestone horizon. At the same time the average body dimension of the Upper Badenian-Sarmatian reef formations is almost five times larger compared to the Lower Badenian reef formations. A similar picture appears - in inverse proportion - through the thickness and distribution conditions of the heteropic basinal sediment facies.

In summary it can be stated that:

- The "Leitha Limestone" appears in two chronostratigraphic horizons, different in time.

- The two horizons can be well separated in the regional facies areas, throughout the country, and also in the surrounding facies areas of the Carpathian Basin. This statement is also proved by the relevant results of Project IGCP 25 with the correlation sections of the Mediterranean Tethys and Paratethys areas (Steininger et al. [eds.]) 1985). In this study the "Leitha Limestone" can be demonstrated in two horizons (Lanzendorfian and Serravallian) in more than one-third (36\%) of the 45 facies areas of the Carpathian-Balkan region. In almost 
half $(49 \%)$ of the same areas, only the upper horizon developed, deposited predominantly with stratigraphic, erosional or angular unconformity by overlapping on the margins of basins. The "Lower Leitha Limestone" development is concentrated in the western areas of the region and the "Upper Leitha Limestone" in the eastern areas, overlapping each other in the central areas (Styria, Hungary).

Their occurrence in the same section above each other, or the appearance of only the lower or upper formation, are clearly related to the different basins, structurally controled by the different orogenic cycles, and the different paleogeographic conditions.

The distinction is made possible by the characteristic differences of the formations:

- petrographic composition of the formations;

- structural situation of the location of their appearance;

- their stratigraphic position;

- their thickness development, according to their stratigraphic position and lateral changes;

- their footwall-hanging wall conditions;

- their heteropic facies, interfingering with the reef formations, and their percentage;

- the characteristic reef dimensions;

- the layer-statistical and formation-statistical investigation systems, containing a variety of comparisons and proofs and complementing each other;

- last but not least, the biostratigraphic evaluations, extremely work-intensive, that focus mainly on the newly-appearing taxa, the number of common taxa, and extinction of taxa related to facies change, from the evaluation (some data were presented from the investigations in the E Mecsek and Cserhát Mts without country-wide comparison and the aim of completeness).

The evidence of the existence of the two Leitha limestone horizons contributes significantly to the subdivision of the Miocene into three main stages.

\section{Stratigraphic results}

From the detection and delimitation of orogenic cycles (Hámor 1978, 1984), to be discussed below in detail, the two most important chronostratigraphic results of layer-statistical investigations are clear: it could be proved that, following the analytical phase of Neogene research, further development of chronostratigraphy, and amalgamation can take place, with the aim of creating major stages. This is partly a return to the classic Mediterranean I, Mediterranean II subdivisions that were created by preceding workers, on the basis of their substantial knowledge of the subject matter. The proposals of the author of the present study on interpreting them and making them more precise were published on the basis of the results of monographic summaries and repeated regional-interregional map compilations (Hámor 1997; Hámor and Halmai 1995). 
Another important result is considered to be the exact, quantitative analysis and characterization, wide-ranging discussion, publication and application of formation and member level elements of the lithostratigraphic system, which has been established in the course of the last two decades.

\section{Early Miocene}

The Early Miocene (proposed main stage name: Atlantian) includes the Eggenburgian-Ottnangian time. The sedimentary sequence of the "Upper Egerian" substage, assigned to this time according to certain opinions, is clearly the regressive phase of the Oligocene sedimentary cycle, with special regard to the end-of-cycle freshwater, paludal and carbonaceous formations, which developed beneath the cover of the marine series, and to the regional elevation.

The beginning of the Miocene is marked by renewed, continent-wide transgression, developed in those basins that were preformed by the Savic orogenic cycle, mostly in the northern Perialpine Foreland and ranging from the Indopacific to the Atlantic realm. The two-phased transgression is composed of the total Eggenburgian sedimentary cycle (continental-transitional-marinecontinental) and an Ottnangian half-cycle (continental-transitional-marine). The two sedimentary cycles are separated by intercyclic rhyolite-ignimbrite series.

A new result of the present study is the finding of a heretofore undocumented Hungarian formation of Early Miocene flyschoid molasse facies, presumed to have been deposited E of the Neo-Vardar Ridge. This Kettősmező Formation, spreading from the Szilágyság, Northern Transylvania and starting with a conglomerate base, has so far only been found in the area of the Sajó Trough in 6 deep boreholes in the neighborhood of Penészlek, Nyírábrány, Nyírlugos, Hajdúhadház and Kisújszállás.

The thick marine series of mixed epicontinental-molasse facies, detected in 9 boreholes to the $\mathrm{W}$ of the Neo-Vardar Ridge, in the Zala-Drava Trough in the surroundings of Kerkáskápolna, Budafa, Lovászi, Liszó, Oltárc and Bajcsa is of similar significance and, based on correlatable stratigraphic units, is coeval with the continental series.

On the two flanks of the Neo-Vardar Ridge, the lignite formation period of Ottnangian age is also well-correlatable in freshwater and paludal development in the west, and in marine and paralic development in the east (Mecseknádasd Member of the Szászvár Formation, Brennberg Lignite Formation, as well as Salgótarján Lignite Formation).

An important partial result is the proof of Eggenburgian-Ottnangian continental sedimentation thanks to the re-evaluation of some 25 boreholes in the Little Plain, in the southern part of the Danube-Tisza Interfluve, and in certain trough systems of the southeastern Trans-Tisza area. The fluvial sediment transport in the opposite direction took place to the $\mathrm{W}$ of the Neo-Vardar Ridge 
toward the Adriatic Basin, and to its E to the Transylvanian-Black Sea basin (Hámor 2001b).

In the marine development the Upper Egerian-Eggenburgian boundary can be clearly designated by the appearance of a new macrofauna invasion ("Larger Pecten-bearing layers"). Based on a wide-ranging overview it can be stated that this unit was formed only in certain trough systems of the basinal area of the former Oligocene; its overlapping on the Paleo-Mesozoic substrate is unique and rare and cannot be expressed in percentages. At the same time, the overlapping of the continental formations, and thus the lower boundary of the Early Miocene, is significant due to the hinterland elevation. This is very pronounced in the territory of the Little Plain and in the areas of Hungary to the S of the "Balaton Line", since Paleogene formations there are rare. According to Table 2, this overlapping amounts to more than $22 \%$ of the country-wide lateral extension of the entire Neogene and $88 \%$ of the extension frequency of the Early Miocene.

The other consequence of the afore-mentioned hinterland elevation is the gradual bog formation within the increasingly restricted basin space, and the formation of the lignite seam(s); therefore the Eggenburgian-Ottnangian cannot be biostratigraphically separated within the continental development. Although traces of the Ottnangian transgression, limited to northeastern Hungary, appear in the upper paralic part of the lignite formation, among the fauna of barren intercalations (NN3 zone; Nagymarosi 2001), their regional correlation has not been carried out up to the present. The upper boundary of the above-mentioned formations is an erosional unconformity developed in connection with the Karpatian transgression. It is reasonable to amalgamate the formations and members situated between the above-designated lower and upper boundaries, within the main Early Miocene unit.

\section{Middle Miocene}

The Middle Miocene (proposed main stage name: Mediterranean) includes the Karpatian-Lower Badenian-Middle Badenian time. The beginning of the Middle Miocene is determined by renewed transgression, ranging from the Mediterranean to the Caspian Region due to the Styrian orogenic cycle, and covering equally the northern and southern forelands of the Alpine-CarpathianCaucasian system.

This opportunity was provided by the formerly elevated and at this time collapsed Dinaridic Gate: a direct connection was formed between the AtlanticMediterranean areas and those to their E. The two-phased transgression is proved by the total sedimentary cycle, developed in the old Styrian phase during the Karpatian, and the similarly total Lower Badenian-Middle Badenian sedimentary cycle, determined by the new Styrian phase. Both phases and cycles are characterized by marine formations - basin sediments of maximum marine 
transgression, then regression, salinity crisis, and in some cases formation of dry land.

The transgressions advanced northeastward and eastward in the SW-NEvergent trough systems. During the Styrian orogenic cycle, the Neo-Vardar Ridge, itself of NW-SE direction, did not influence the extent of the basin, but had a moderate effect upon its facies conditions - especially at the time of the upper boundaries of the two phases of the orogenic cycle.

During the investigation of the Karpatian-Badenian, new and important results emerged, concerning 5 basic stratigraphic questions:

- The total lateral series of the coeval heteropic facies could be demonstrated by formation-statistical investigations. While the marginal equivalents of the Karpatian "schlier" are the Egyházasgerge Formation and its synonyms, those of the "Badenian Clay" series are the "Lower Leitha Limestones" (Pécsszabolcs Formation and its synonyms).

- The Karpatian and Lower Badenian (including "Middle Badenian") sequences can also be easily distinguished on a biostratigraphic basis. In addition, the remarkable difference in the average thickness of the transgressional basal formations (twice that of the former), the different pebble quality owing to the different structure of the coastline, and the much simpler lateral facies series of the Badenian time make the separation even simpler. All three factors can be attributed to paleomorphological conditions along the coastline, already simplified by the time of the Badenian, as well as the different energy conditions of the two geologic supercycles.

- An important stratigraphic element is the identification of the regressive branch of Karpatian geologic supercycles (Fót Formation and its members) over the entire country. During the same period the so-called "Middle Rhyolite Tuff" and the partly submarine volcanic and volcanosediment beds of the Hasznos Andesite Formation also serve as good markers.

- An outstanding result is that the "Middle Badenian" formations are evidently products of the regression flank, closing the Lower Badenian geologic supercycle. Oscillating facies changes of the series with transitions of continuous sedimentation (Hidas Lignite Formation), already previously known, could be complemented and enriched in Transdanubia and Eastern Hungary. They may establish a connection with the huge lagoonal series on the inner (more rarely outer) arch of the Carpathians, the thick salt beds of which came into being at this time (halite areas in Eastern Slovakia, Sub-Carpathia, Romania and Southern Poland). The heaviest Tertiary volcanic paroxysm took place in the inner, central territories of the Carpathian Basin, on the two flanks of the Neo-Vardar Ridge, during this period. Its magmagenetic evaluation and age classification is based mainly on the recognition of the new formations (Sámsonháza, Abony), interfingering with the volcanites.

- The fifth important result is that new prospects were opened to further prove the subdivision of the Badenian. The Leitha orogenic cycle, proved as a new one 
during the revision of the orogenic cycles (Hámor 1978, 1984), provided orokinetic hinterland for the two-division model of the Badenian stage. This result was obtained by the analysis of the formations before and after the volcanic paroxysm (salinity crisis), principally the formation-statistical investigation of the stratigraphic position of the "Lower" and "Upper Leitha Limestone". The latter results have already been presented as an important part of the present study in Section 7.

On the basis of the above it appears to be practical to use the former Lower and Upper Badenian substage subdivision instead of the three-division Badenian, and to assign the Middle Badenian time and its lithological unit to the Lower Badenian.

What then is the reason for amalgamating the Karpatian Stage and the Lower Badenian Substage into the Middle Miocene main stage?

Among several important arguments, a decisive one is that there are no significant differences between the old and new Styrian phases in terms of structural formation. The already mentioned longitudinal (NE-SW-vergent) trough systems were developed by means of cyclically intensifying and weakening, but continuous, tectonic impulses. Their effects can be detected in detail in the marginal-nearshore facies areas; the orogenic events were not manifested by the development of regional hinterlands or mountains. Basically only the vertical oscillation of the basin basement controlled the formation of the sedimentary pattern.

The structural picture, the paleogeographic conditions, and the extent of the basinal troughs remain unchanged. This is proved by the fact that at the beginning of the Styrian cycle, overlapping of the Karpatian basins is $17.5 \%$ of the lateral Neogene extent (which is significant), while the percentage during the Lower Badenian is only $2.2 \%$. This can be explained by the local paleomorphological differences or even the calculation error limit of the method. Constancy is reflected by the nearly the same thickness of Karpatian and Lower Badenian sediments of basinal facies in the country-wide average, the position of the facies belts (almost totally covering each other), the "striking similarity" of their mass ratios, and even the vertical thickness of the interfingering of their facies belts (see Table 17). It is remarkable that the structurally-determined areas of extent of the end-Karpatian and end-Lower Badenian ("Middle Badenian") volcanites are also roughly the same.

Table 17

The typically identical layer-statistical data of the Styrian sedimentary cycles on the basis of countrywide averages

\begin{tabular}{|l|c|c|c|c|c|}
\hline $\begin{array}{l}\text { Old and new Styrian } \\
\text { sedimentary cycles }\end{array}$ & $\begin{array}{c}\text { Thickness of } \\
\text { basin facies } \\
(\mathbf{m})\end{array}$ & $\begin{array}{c}\text { Mass ratio of } \\
\text { marginal facies } \\
(\mathbf{\%})\end{array}$ & $\begin{array}{c}\text { Mass ratio of } \\
\text { basin facies } \\
(\mathbf{\%})\end{array}$ & $\begin{array}{c}\text { Vertical } \\
\text { interfingering } \\
(\mathbf{m})\end{array}$ & $\begin{array}{c}\text { Evaluated } \\
\text { drillings } \\
\text { (pcs) }\end{array}$ \\
\hline Old Styrian, Karpatian & 279 & 56.4 & 43.6 & 307 & 267 \\
\hline $\begin{array}{l}\text { New Styrian, Lower } \\
\text { Badenian }\end{array}$ & 302 & 53.8 & 46.2 & 298 & 148 \\
\hline
\end{tabular}


The similarities in space and time dimensions are obvious. All this is supported by the fact that the series of Karpatian-Lower Badenian continuous sections can also be regarded as a single geologic supercycle in much of the basinal areas. This supercycle can be characterized by marine sedimentation, beginning with the first Karpatian transgression and lasting without interruption until the end of the Lower Badenian s.s., and closing by interregional general elevation, evaporitization, as well as extremely intense volcanic activity during the "Middle Badenian". This continuity may explain the continuous changes and evolution of the faunal associations in the course of the repeated transgressions. The delimitation problems are reflected in uncertainties of mollusk-foraminifer zonations and difficulties in detection and delimitation of the NN4-NN5 nannozones. However, the sharp biostratigraphic changes on the lower and upper boundaries make the delimitation from the Early Miocene (NN3 nannozone) and Late Miocene (actually the Upper Badenian) clear. Within the area of Hungary, the NN6 nannozone also causes detection problems due to the proximity of the Eastern Paratethys.

\section{Late Miocene}

The Late Miocene (proposed main stage name: Caspian) contains the Upper Badenian-Sarmatian-Pannonian time. In the Carpathian Basin, its beginning and extent are marked by renewed transgressions appearing in the Pannonian Basin, which had undergone subsidence by this time due the Leitha orogenic cycle. The orogenic cycle was triggered by the repeated collisions of the African and Eurasian plates. Its direct effect was manifested in the uplift of the Dinarides, the Eastern Alpine system, and the Western Carpathians. The basin formation, however, previously considered to be uniform, occurred in three units in the areas of the western and eastern sub-basins and the Neo-Vardar Ridge, resulting in their separation. The new orographic picture of the Pannonian Basin and its inselbergs came into being at this time and only at this time. The situation and paleogeographic connections of the Middle Miocene depocenters underwent a radical change. Due to the emergence of the above-mentioned mountainous areas the slope conditions switched to southeasterly direction. The transgressions, coming from the eastern Paratethys, advanced further northwestward. With the direct deposition on the substrate of the Upper Badenian initial (mainly reefal) formations, this can be followed along the following route: BourgasVarna-Getic Depression-Danube (Iron Gate) Trough-Timok Trough-southern and eastern margins of the Transylvanian Basin-Bega Basin (Lapugy)-southern Banat-western Serbia-Drava Basin-Leitha Mts-southern part of the Vienna Basin. The paleomorphological pattern is complemented by smaller movements, which influenced the vertical movements at the structural boundary lines of the tectonic units (Tisza Mega-unit and Pelso Mega-unit and their subunits) of the Paleo-Mesozoic basement; later these positive topographic forms played a decisive role in the development of the Late Miocene reef systems. 
The layer-statistical investigations complemented the stratigraphic knowledge of the Late Miocene with significant new results, and produced a new evaluation of a crucial new aspect:

- Concerning the question of the delimitation from Lower Badenian, these results are the role of the "Middle Badenian" volcanic crisis and the proof of the two separate Leitha limestone horizons. The correlation sections of the referred Project IGCP 25 determine the age of the Lower Leitha limestone as Lanzendorfian (=Lower Badenian) in 15\% of the areas and that of the Upper Leitha limestone as Early Serravallian (=Upper Badenian) in $85 \%$ of the areas (Steininger et al. [eds]) 1985).

- The upper boundary of the Late Miocene (if the Pontian series are not considered as assigned to the Miocene) is determined by the last phase of the Leitha orogenic cycle or (as its equivalent) the beginning of the Rhodanian orogenic cycle. At that time the vertical emergence of the hinterland cordilleras and the inselbergs accelerated significantly, along with a less intensive basin subsidence. This led to the termination of the last deep water turbiditic development, the Szolnok Sandstone Formation of Pannonian age, as well as the evolution of the Algyő Formation (delta slope) near the elevated margins that later prograded towards the basin center. The inflexion point of the geologic supercycle can be designated at the boundary of the two formations, which at the same time is the beginning of intensive filling up of the Pannonian Basin with delta sediments, lasting to the Quaternary. It is also a Pannonian-Pontian boundary event.

- As a consequence of the above the Algyó Formation can be assigned in time to the Pontian Stage. The biostratigraphic problems concerning this will be dealt with further on.

- The Late Miocene consists of half of three geologic supercycles, created by repeated transgression; all three lasted from the initial marginal formations to the time of maximum transgression - together with its lateral facies belts. The first transgression, following rapid subsidence during the Upper Badenian (without continental sediments) covered huge areas with shore, reefal, and locally ingressive basinal developments. This overlapping amounts to nearly one quarter $(23.1 \%)$ of the total extent of the Hungarian Neogene and can be characterized by an areal/regional unconformity. In this case its formations are deposited with hiatus on the Paleo-Mesozoic or Paleogene basement, or on older Miocene formations in all cases.

The Sarmatian transgression - ignoring the continent-wide decrease, followed by increase to hypersalinity, of the salt content of water - increased by $6.8 \%$ the area of the basin in the same development and deposition. Due to the subsidence of the basin basement, the expansion of the Pannonian is even larger, namely $16.3 \%$. All three sedimentary cycles occurred under practically continuous sedimentation conditions in the basins. 
- The Sarmatian-Pannonian boundary is represented by the transitional formations of the "Zala Platy Marls" in the basinal facies. At the margins the appearance of the Sarmatian layers, and above them the Pannonian coarsegrained sands grading into pebbles, can be regarded as the first signs of delta evolution, already beginning at this time (e.g. Malom Lake-Miklós Hill, Sopron; Mecsek Mts-Pécsbánya).

- An important result is considered to be the recognition of the extent of the Sarmatian episodic evaporitization in the Mezóföld area (Zala County, Mecsek Mts of northern Hungary) and the Danube-Tisza Interfluve, deposited between marine footwall-hanging wall formations, first identified in the Transdanubian Range (Budajenő Formation; Jámbor 1976). Their correlation with the evaporite traces in Sarmatian continental intramontane formations has also been carried out (Bakony Mts, Cserhát Mts, Gödöllő hill country). The Kryzanowice Gypsum Formation in Southern Poland, revised to the Late Badenian (Serravallian)/ Sarmatian boundary, is also remarkable and proves the regional-scale appearance of the Sarmatian evaporitic crisis outside the Pannonian Basin (Becker 2005).

- The detection of the second great volcanic paroxysm connected to Sarmatian time, the formations of the thick "Upper Rhyolite Tuff" and the "Uppermost Rhyolite Tuff", also extending into the Pannonian, in the territory of the Szatmár Trough and a part of Hajdúság (Tokaj and Nyírség Formations) may also contribute to the stratigraphic evaluation of the Sarmatian-Pannonian, since they can be demonstrated in an attenuated form in the entire country.

On the basis of the wider knowledge of paleogeographic conditions and faunal migrations, certain geologic supercycles can also be well characterized on the basis biostratigraphy. The faunal associations of the Upper Badenian cycle show an extremely diversified picture: in the residual basins the Mediterranean elements of the Middle Miocene, the Pecten-like forms, certain gastropod genera, the still stenohaline larger foraminifera (Heterostegina, Peneroplis), and benthonic foraminifer assemblages (Bulimina-Bolivina zone) mix with the Indopacific elements coming from a greater distance (Decapods, Pteropods). Toward the end of the cycle, near the Sarmatian boundary, the more proximal Eastern European "Conca"- and "Veselianka"-type (already eurihaline) mollusk fauna also appears (Hámor 1970; Kókay 1985).

The clearly brackish-water fauna of the Sarmatian sedimentary cycle originated in the Aralo-Caspian areas, with characteristic mollusk associations (predominantly Irus, Mactra, Ervilia, Cerithium-Hydrobia elements) and impoverished benthonic foraminifer fauna (predominant Nonion-, Elphidium-like forms; Boda 1971).

The biostratigraphic evaluation of the Pannonian sedimentary cycle is the subject of centuries-old debate. The fauna of the "Congeria Stage" (Böckh 1876) is generally explained by endemism due to filling up and dilution, and in extreme cases to hypersalinity. A problem is, however, that this cannot be clearly deduced 
phylogenetically; there are hardly any antecedents of the rich CongeriaLimnocardium-Melanopsis fauna. It is clear, however, that their close relationship, formed in the region of the Eastern Parathetys, was transported by repeated transgressions in a marine facies (though with a strongly varying salt content, or brackish water) northeastward up to the surroundings of the Timok Trough / Iron Gate (Stevanović 1986; Taktakisvili 1987). In the inner areas of the Pannonian Basin these faunal assemblages mixed with freshwater ones, enduring the extremely variable salt content resulting from the freshwater input derived from paleogeographic changes, regressional small cycles, and intensifying delta evolution (according to the hypothesis of the author). The lithostratigraphic system, which well reflects the evolutionary history of the Hungarian Late Miocene, renders this model probable.

In spite of the possibilities of subdivision presented previously, the introduction of the Late Miocene main stage as a chronostratigraphic unit is justified by the points below:

- Revising the event history and extension of the Leitha orogenic cycle again, it was found that its phases, appearing as stages, form a continuous succession. Thus, the Rhodanian Orogene, regarded as a separate cycle, is "only" a phase of the Leitha orogenic cycle that can be distinguished under the Rhodanian name.

- The entire orogenic cycle took place within an unchanged tectonic framework in the area of the western and eastern Pannonian Basins, which developed at the beginning of the Upper Badenian, and the intermediate NeoVardar Ridge. This is proved by the continuous increase in basin space, the balance of basin formation and hinterland elevation. Thus, the orogenic cycle contains the period of Upper Badenian-Sarmatian-Pannonian-Pontian and mostly also the Quaternary, not even excluding its activity with influence up to Recent times.

- The operation of the model is supported by the course of the geologic supercycle, with the same extension in time that could even be called a megacycle. The transgressive phase of the cycle lasted from the Upper Badenian to the middle part of the Pannonian, mainly with transgressive middle cycles. Its inflexion point can be found at the boundary of the deep-water turbiditic Pannonian Szolnok Formation and the Algyő Formation. Its regressive branch is represented by the Algyô Formation delta slope, the Újfalu Formation delta front, and the Zagyva Formation delta hinterland (delta plain), prograding as a result of the termination of basement subsidence and intensification of hinterland elevation, and the lignite formations of widespread bog formation (MátraBükkalja and Toronyi Lignite Formations) followed by the Nagyalföld Variegated Clay Formation, which exceeds $500 \mathrm{~m}$ in thickness. The megacycle is also documented by the synorogenic volcanic series of mixed facies of the Szatmár Trough, connected to basin formation, and repeated basalt volcanism connected to the marginal faults at the flanks of the Neo-Vardar Ridge during the hinterland elevation, both in Hungary and in surrounding areas. 
- The continuity of the cycle is also proved by the practically unchanged paleogeographic situation and the identical course of facies belts of different age that can be documented by the formation-statistical investigations. It can be clearly shown that the basement structures, which determine the facies, did not change during the transgressive phase of the cycle: for example, the Upper Badenian reefal belts continued to be further developed in the early Sarmatian and Pannonian, and the spatial situation of the pelitic series of the basinal facies shows a similar trend. The thickness of the reefal formations decreases with time, and that of the basinal formations increases; however, their differences are within an acceptable range (see Table 16). During the regressive phase of the cycle the facies reordering (due to hinterland elevation) has a double result: as a consequence of ablation and burial, the basement became paleomorphologically more balanced; the ridges and ribs were buried, although their thickness development still differed significantly from the sediment thickness of the basinal areas (Mihályi, Battonya, Neo-Vardar Ridges). At the same time, the areal extent of the basin increased: the slopes of the basin were transformed into basins due to the marginal faults of the uneven hinterland elevation. The spread of the Algyő Formation, a delta prograding onto the slope, is about $2-5 \%$; for example, in the valley of the Körös rivers it is deposited directly on the substrate in the structural blocks of the Kunság Trough-Jászság, in spite of the overall regression (see Fig. 8). Due to the lateral extent controlled by filling up of the basin, the expansion of the Újfalu Formation (of fluvial and delta front facies) still increases the area of Neogene extent by $11.9 \%$ in the country-wide comparison. The country-wide average thickness of the total Late Miocene supercycle increases consistently from NW to SE; the displacement of the depocenters also supports the continuity of the orogenic cycle and the geologic supercycle (Table 18).

Table 18

Characteristic layer-statistical data of the Leitha sedimentary cycle on the basis of country-wide averages

\begin{tabular}{|l|c|c|c|c|c|c|}
\hline Age & $\begin{array}{c}\text { Basin } \\
\text { thickness } \\
(\mathbf{m})\end{array}$ & $\begin{array}{c}\text { Percentage } \\
\mathbf{( \% )}\end{array}$ & $\begin{array}{c}\text { Marginal } \\
\text { thickness } \\
(\mathbf{m})\end{array}$ & $\begin{array}{c}\text { Percentage } \\
\mathbf{( \% )}\end{array}$ & $\begin{array}{c}\text { Interfingering } \\
\mathbf{( m )}\end{array}$ & $\begin{array}{c}\text { Drillings } \\
\text { (pcs) }\end{array}$ \\
\hline Upper Badenian & 116 & 36 & 64 & 20 & 141 & 252 \\
\hline Sarmatian & 213 & 47 & 52 & 12 & 188 & 213 \\
\hline Pannonian & 216 & 48 & 45 & 9 & 190 & 216 \\
\hline $\begin{array}{l}\text { Pontian (including } \\
\text { the Algyő Fm.) }\end{array}$ & 1,565 & 47 & 448 & 28 & 596 & 783 \\
\hline
\end{tabular}


Comparative sedimentary geologic and paleoclimatic diagram of the Hungarian Neogene megacycles and major stages

The correlation of the Neogene climatic changes occurring during sedimentation with the qualitative and quantitative data of the lithostratigraphic units proved to be a useful checking method for stratigraphic evaluation (Fig. 9). The basis of the comparison is the Neogene climatic curve, published in the study of Nagy (2005). Its most important element is the evaluation and separation of the flora elements of the height-temperature zonation, determined by global climatic changes and geomorphological conditions. Its result is the first Hungarian Neogene climatic curve to be based on quantitative data, unaffected by the latter condition and containing temperature values. On the basis of the predominant sporomorphs, changes in climate in the subdivision of tropical, subtropical, and temperate zones will be discussed.

For the Neogene the climatic curve proves continuous cooling with undulation interludes. Within it, the average mean temperature of the Early Miocene (Upper Egerian-Eggenburgian-Ottnangian) varies between 19 and $15{ }^{\circ} \mathrm{C}$, that of the Middle Miocene (Karpatian-Lower Badenian-Middle Badenian) between 18 and $14^{\circ} \mathrm{C}$, and that of the Late Miocene (Upper Badenian-Pontian) between 14.5 and $11{ }^{\circ} \mathrm{C}$. It is remarkable that during the Neogene the proportion of tropical elements decreases to one-tenth and that of subtropical elements to half, while the percentage of the temperate zone sporomorphs in the specific drilled sections increases continuously through time up to the Recent. The results of the evaluation can also be well correlated with the data of the pronounced global changes, plate movements, and sea level changes.

Plotting the qualitative (facies) and quantitative (thickness development) data of the lithostratigraphic system alongside this diagram, the two graphs show changes along the axis that roughly correlate.

The striking differences between the main stages can be characterized by the intense warming in the Early Miocene following the cooling at the end of the Oligocene, by the many tropical elements, by the more balanced Middle Miocene subtropical conditions, and by the initially similar, later gradually cooling Late Miocene temperate zone climate.

The facies conditions at stage level are well reflected by the relatively significant differences of the climatic curve - even on the basis of averaged data. The emergence of reefs or reef-like formations, developed in a tropicalsubtropical climate, can be clearly correlated with the climatic changes indicating a warm period. In the text figure, this is proved by the plotted occurrence locations of the Eggenburgian (Budafok Formation), the end-Karpatian (Fót Formation), the Lower Badenian (Pécsszabolcs Formation, "Lower Leitha Limestone"), the Upper Badenian (Rákos Leitha Limestone Formation), followed by the Sarmatian (Tinnye Formation) and the Early Pannonian (Békés Conglomerate Member, Tótkomlós Calcareous Marl Member). It is remarkable that the predominantly red, variegated continental formations of the Early 


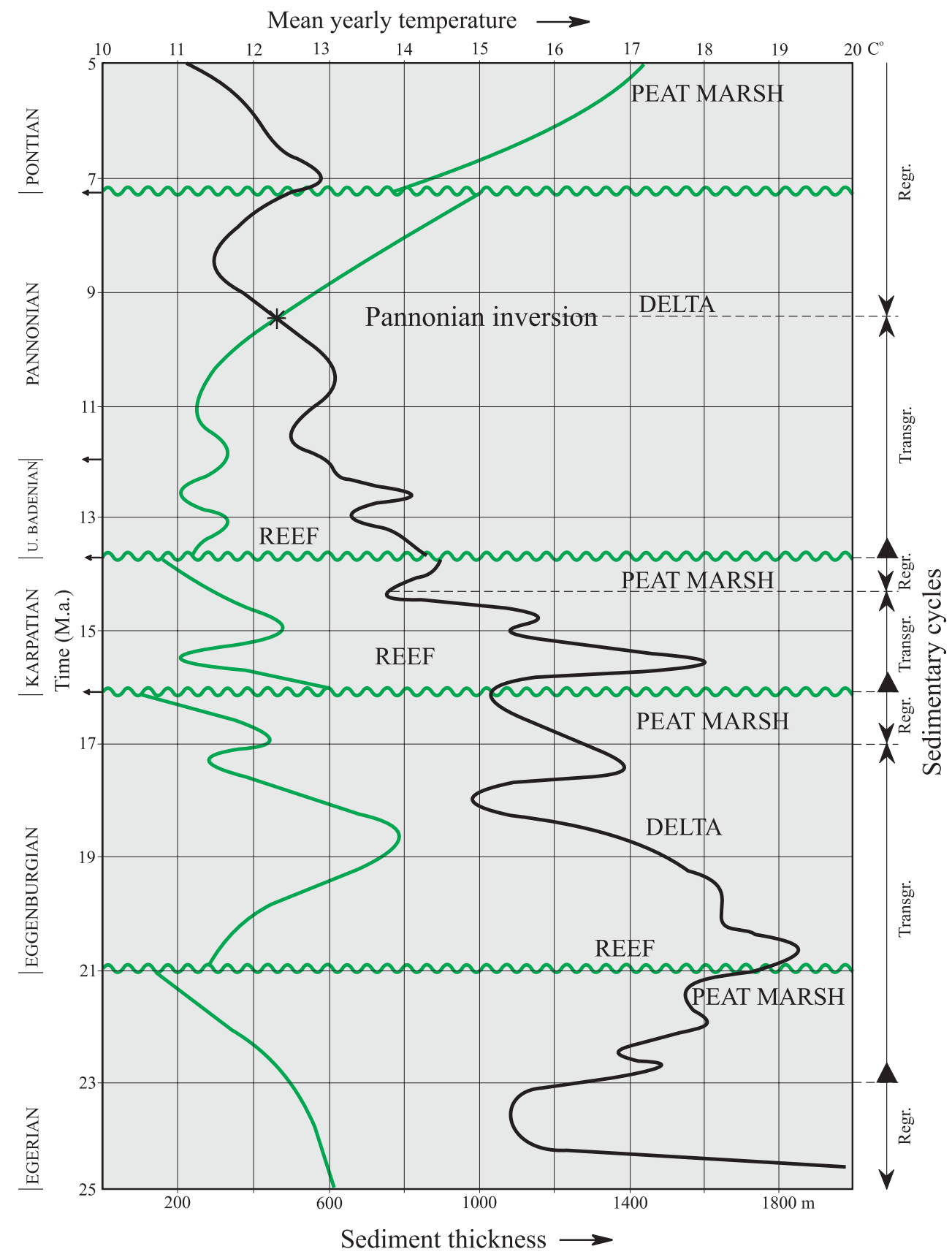

Fig. 9

Sediment thickness, facies and climate change correlation diagram of the Neogene in Hungary (climate curve after Nagy 2005) 
Miocene (Szászvár Formation, lower part of the Máza Member) were also formed under a tropical or subtropical climate. However, the cooling leads to the appearance of the "green sandstone" series, which becomes predominant in the upper part of this same member. This is also confirmed by the fact that, within the given climatic or geologic supercycle, lignite formation coincides with the cooler, humid and temperate periods, and mostly represents end-of-cycle sections. This is proved by the lignite formation at the end of the Oligocene (Becske Formation), at the end of the Early Miocene (Salgótarján Lignite Formation), at the end of the Middle Miocene (Hidas Lignite Formation), as well as at the end-Late Miocene lignite formation (Mátra-Bükkalja and Toronyi Lignite Formations) in Hungary and the other facies areas of the Carpathian Basin.

It appears to be a general rule that the molasse-like sediments developed in the temperate zone in greater thickness; the warmer climate favored thinner - but more varied epicontinental development.

Unfortunately, due to the geologic-paleoenvironmental circumstances of Hungary, our data on the extreme climatic conditions of the Middle Badenian and Messinian "salinity crises" are incomplete. However, it is perhaps not an exaggeration to correlate the undulations seen on the climatic curve, namely the late Karpatian local salification (Tuzla, Zbudza) with the septarian-gypsiferous clays in the Mecsekjánosi Beds of the Fót Formation, or the Sarmatian evaporate traces (Budajenő Formation) and diatom enrichments with the relative local warming, or the "Upper Pannonian" dolomite with the Messinian salinity crisis (Hámor 1992).

\section{Evaluation of the Neogene structural formation and volcanism in the light of the layer-statistical investigations}

The layer-statistical investigations partly confirmed the validity of the previous statements, and partly called attention to new interconnections. They indicate the continuity of the evolution, duration, and delimitation of the orogenic cycles and their phases, the tectonic units created by them, the new or rejuvenated structural elements, as well as the structurally determined sites and dimensions of the related volcanic activity.

The statistical evaluation of the stratigraphic conditions, extent, facies proportions and thickness development clearly reflects the existence of three major Neogene orogenic cycles. The cycles determine the creation of the tectonic framework, as well as the entire magmatic activity. At the same time, the phases, and within them the compressive and extensional rhythms, determine the different mobility of the paleomorphological units, the facies conditions and the mass ratios of the sediments.

The characteristic tectonic elements of the Savic orogenic cycle are partly the filling up of end-Oligocene basins, partly the structural troughs of varying direction and slope. Among them the most important are the SE-sloping Etes, 
Ozd-Egercsehi and Sajó Troughs (in SE Hungary up to the state border), the NW, then W-sloping southwestern Danube-Tisza Interfluve-Somogy Trough, and the SW-sloping trough in the northwestern foreland of the Transdanubian Range, with a N Zala-Drava continuation. The NW-SE-vergent Neo-Vardar Ridge in the central part of the country, the E-W-striking Baranya Island in the south, and the Hungarian Range in its entire length, can already be detected at this time as elevated, separating zones.

The volcanic activity can be connected to NE-SW-vergent structural lines: andesite monovolcanoes along the Balaton Line and the range of imbricated (schuppen) structures of the Mecsek Mts from Komló to Szekszárd, rhyolite ignimbrites erupting along dilatative fissures ("Lower Rhyolite Tuff") along the Mid-Hungarian Lineament in the neighborhood of Kaposfö-DunaújvárosLajosmizse-Bucsa-Karcag (see Fig. 3).

The main elements of the Styrian orogenic cycle are NE-SW-running parallel trough systems with a uniform SW slope - occasionally with transversal connections. These structures almost invariably existed during both phases of the orogenic cycle - with slight differences. This justifies, for example, the amalgamation of the Karpatian-Lower Badenian chronostratigraphic units into the Middle Miocene as a "Mediterranean main stage". From the NW, the trough systems are as follows:

- E Styrian Trough-N Zala-Little Plain (complemented with the Csapod Trough in the new Styrian phase)-Slovakian Danube Basin;

- Drava Basin-Somogy Trough-southern foreland of the Northern RangeEastern Slovakia (with connections toward the Kunság Trough-Jászság Trough system);

- Sava Trough-S Mecsek Mts-Kiskunhalas-Békés-Derecske Trough up to Szilágyság.

Most of the above-mentioned hinterlands, as well as the blocks (Bugyi, Solt, Rém, Madaras) preserved between the troughs of the Neo-Vardar, Battonya, Mihályi, Ortaháza, Inke-Igal and Görgeteg-Babócsa ridges acted as elevated areas. The volcanic activity was concentrated on the structural lines of the western and eastern flanks of the Neo-Vardar Ridge, with rhyodacitic-dacitic explosive and country-wide dispersed tuffs from compressive zones. The fissure systems of the "Middle Rhyolite Tuff" to the W of the Ridge are the Váli-vízNagydorog-Tengelic-Szekszárd Line, those on the Ridge are the Óbuda-SáriKecskemét South Line, those to the E of the Ridge are the Etes Trough-Central Mátra Mts-Tarna Line Zone and in the Szatmár Trough. Fissure zones also occur in the parallel systems of the Mecsek, Bakony, and southern Bükk Mts (see Fig. $4)$.

A decisive phenomenon of the Leitha orogenic cycle is the basin formation. The process is represented in Figs 6 and 7; Fig. 2 and Table 19 show the sedimentary evidence and the subdivision of the partial areas. 


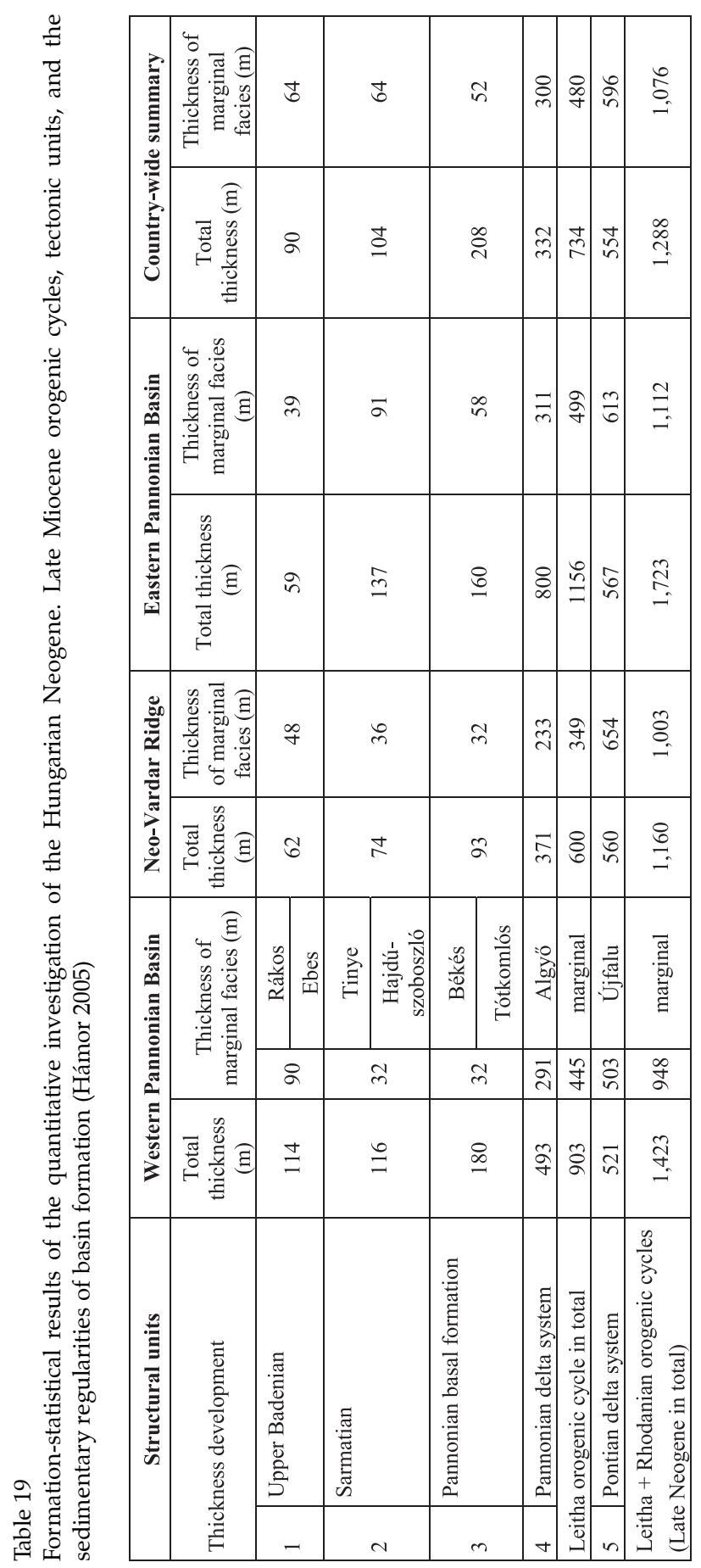


At this time the Alpine-Dinaridic-Carpathian mountain system and most of the inner inselbergs emerged; the Pannonian Basin was also formed and began to intensively subside. In spite of apparent uniformity the Western Pannonian and Eastern Pannonian Basins are definitely separated. The submarine NeoVardar System, acting paleogeographically as a relative elevation, separates the two sub-basins throughout the entire orogenic cycle. Its effect is manifested mainly in the formation of the facies belts of the basins and in differences of sediment thickness. Its mobility, less active compared to that of the basins, is caused by the stiffening effect of the andesite volcanic pile, which covered the ridge during the Styrian orogenic cycle.

In the area of the blocks preserved during the Styrian cycle, its total submergence following the Upper Badenian and Sarmatian transgressions only occurred at the beginning of the Pannonian. The Mihályi and Battonya Ridges, as well as the previously mentioned ones (e.g. Igal, Ortaháza, Görgeteg; see Fig. 7) were also submerged at this time. In addition to the above, the pronounced result of the structural formation is the development of deep troughs of NW-SE direction at this time. Its representatives are the Zala-Drava Trough in the west, the Kecskemét (Kada)-Hódmezóvásárhely-Makó-Kikinda Trough in the east, as well as the Eastern Slovakian Szatmár Trough.

The rate of basement subsidence increases continuously in the Pannonian Basin from the Upper Badenian to the middle of the Pannonian. It reaches its maximum at the time of the development of the deepest water Szolnok Sandstone Formation. The inflexion point of the Upper Miocene geologic supercycle was designated at its end, where the transgressive phase turns into the regressive one (see Fig. 8). At the same time, this marks the appearance of the Rhodanian phase of the Leitha orogenic cycle, the extensional effect of which baused the basin basement subsidence to slow down, with simultaneous hinterland elevation. The facies change is generally indicated by the appearance of the delta formations, with the deposition above each other of the delta slope (Algyó Formation), delta front (Újfalu Formation), and delta hinterland (Zagyva Formation) formations within it, and the displacement in time of the delta system, prograding basinward. The tectonic-paleogeographic result of the Rhodanian orogenic phase is that the already extensive delta slopes and fronts are locally deposited directly on the substrate. Thus, in addition to the intensification of hinterland elevation and sedimentary spreading, the structural zones in question also play a role in the formation of the Pannonian sequences.

The sedimentation rate is highest in the Eastern Pannonian Basin; basement subsidence also lasted longest. Consequently the thickness of the Quaternary Nagyalföld Variegated Clay Formation, for example, is more than $500 \mathrm{~m}$. The largest Hungarian Neogene sediment thickness can also be found in this part of the basin. It is about 7,000 m in the Makó-Hódmezóvásárhely Trough, and approximately the same in the Slovakian part of the Győr Basin. 
The Szatmár Trough belongs to the youngest tectonic elements of the Leitha orogenic cycle and is filled up by a 3,000-4,000 m-thick volcanic series of Sarmatian-Pannonian age, mainly over unknown basement (Tokaj and Nyírség Formations). The earlier "Middle Rhyolite Tuff" and the intensive SarmatianPannonian volcanic tuff dispersion ("Upper Rhyolite Tuff" and "Uppermost Rhyolite Tuff"), belonging to the Leitha orogenic cycle, are also derived from this magmatic system. Along the western marginal faults of the Neo-Vardar Ridge a series of basalt monovolcanoes (Kecel Basalt Formation) came into being at the beginning of the Pannonian. During the Rhodanian phase, intensive basalt volcanism occurred even at this time, along the flanks of the Neo-Vardar Zone (Tapolca and Salgóvár Basalt Formations).

Spectacular structural elements of the Rhodanian phase of the cycle are the often multiple marginal faults, baused by hinterland elevation. They are usually unconformably covered by the thick sediments of the Újfalu Formation. As a consequence of the compression of hinterland elevation imbricated overthrusts are pronounced structural elements. Most of these are also covered and as a result can hardly be detected. However, imbricated structures could be detected in significant amounts along the continuation of the classically known PécsMecsekalja Line, along the line Zengővárkony-Lovászhetény-Bugac-Hajdúság, as well as along the Transdanubian part of the Balaton Line. It cannot be excluded that some imbricated overthrusting also continued during a later part of the Rhodanian phase; this is suggested by a few Congeria rhomboidea remnants, found in mylonites (Vitális, in manuscript) as well as the section of borehole Szászvár13 , drilled in the range of imbricated (schuppen) structures of the Mecsek Mts, with layers belonging to the Újfalu Formation encountered beneath the Triassic.

The new structural interconnections outlined above are also clearly reflected by the country-wide large-scale geologic sections (48 of them) at a scale of 1:500,000.

An important result of the conclusions of the geodynamic-structural geologic summary is that the regressive phase of the cycle can already be assigned to the Pontian stage, beginning with the Algyô Formation, on the basis of the interpretation of the Pannonian inversion. This would also correlate well with the events of the global-scale "Messinian" stage and the magmatic events in the Carpathian Basin.

\section{General conclusions}

The compilation of this study had three main goals: i) establishing and testing in practice the methodology of exact quantitative evaluation, ii) providing basic research data for questions concerning Neogene stratigraphy, sedimentary geology, faciology, evolutionary history and paleogeography, as well as structural formation, and iii) applying these data, on the basis of the two previous goals, to geology for mineral resources and land use prognoses, for the different specialized branches of science and regions. 
Among the methodological results rock composition and biofacies evaluations (starting from the basic data) served as a starting point. They were used for the characterization of the structures of the formations and members, acting as building blocks of stratigraphy, in order to complete the quantitative documentation of the lithostratigraphic system of the Hungarian Neogene. As a next step, the vertical and lateral extension, stratigraphic conditions, and dimensions of the system could be determined on the basis of layer statistics. An important result is considered to be that the method also provides an opportunity to use and to fit into the system the old data that can be only evaluated with difficulty, as well as portions and fragments of data, in addition to the outstandingly good datasets. Top products of the method are the paleogeographic reconstructions and paleogeographic maps at different scales, compiled on the basis of the interpretation of the numerical data.

In the field of sedimentary geology, results of basic research value are i) the rendering of the geodynamically-determined course of the geologic supercycles more precise, especially in regard to the end-of-cycle crisis periods, ii) clarifying the source area of the sedimentary material, as well as the direction and energy conditions of material transport, and iii) clearly determining mass ratios. The faciological evaluations brought significant results to understanding the role of the tectonically determined paleomorphology, evaluating the vertical and lateral transitions of the rock bodies in specific facies, and - perhaps most importantly metrically measuring these rock bodies. Knowledge of the stratigraphic and topographic position of the facies belts was considerably expanded on the basis of the statistical evaluation of the heteropic facies. The paleogeographic reconstructions resulted in maps more precise than ever concerning changes in the continental and basinal areas, and expressing the statistically-based probability of coastline and shore distance in objective numerical data. These results enriched and supported, by means of exact proof, the new chronostratigraphic system of the Neogene stratigraphy [including, but not limited to, the Oligocene-Miocene boundary, the interpretation of the Middle Miocene as a new main stage, the continuity of the Upper Badenian-Pannonian and thus of the Upper Miocene, the recognition of the Pannonian inversion at the boundary between the Pannonian and the Pontian, the age determination of the Leitha limestone units and igneous (volcanic) formations of varying age]. The correlation of the stratigraphic results over an increasing extent toward facies areas, regions and interregional areas, partly permitted checking results, and partly allowed continent-wide or global correlation.

The principal aim of use in the field of applied research is definitely the revision of existing mineral resource and land use prognoses, as well as compilation of new ones. The data obtained by the quantitative layer-statistical method are suitable tools (and the only suitable ones) for an objective judgement of the formation, migration, and storage possibilities of raw materials, linked to the individual rock bodies, and for the calculation of reserves within the 
structurally determined units. Neither engineering geology, environmental protection, nor area utilizaton tasks can afford to ignore the increasing use of suitably measured geologic data.

\section{Acknowledgements}

The study was carried out with the support of OTKA application No. T 02902 "Prognostic utilization of paleogeographic reconstruction", MOL PLC, and the Geological Institute of Hungary. The author expresses his warm thanks to Dr. Gyula Varga, Enikő Hámor, Antal Pentelényi, and the editorial staff of Acta Geologica Hungarica for their generous technical assistance for his work. The coloured figures were supported by the Hungarian Geological Institute, and the Hungarian Geological Society.

\section{References}

Becker, A. 2005: Facies development of the Badenian (Middle Miocene) gypsum deposits in the Raclawice area (Miechow upland, Southern Poland). - Ann. Soc. Geol. Pol., 75, pp. 111-120.

Boda, J. 1971: A magyarországi szarmata emelet taglalása a gerinctelen fauna alapján (Gliederung des Sarmats von Ungarn auf Grund der Invertebrata-Fauna). - Földt. Közl., 101/2-3, pp. 107-113 (In Hungarian with German abstract.)

Böckh, J. 1876: Pécs városa környékének földtani és vizi viszonyai (Geologic and hydrologic conditions in the environs of city Pécs). - Ann. Hung. Geol. Inst., 4/4, pp. 129-287 (In Hungarian.)

Gradstein, F, J. Ogg 2004: Geologic Time Scale 2004 - why, how, and where next! - Lethaia, 37/2, pp. $175-181$

Gyalog, L., T. Budai 2004: Javaslatok Magyarország földtani képződményeinek litosztratigráfiai tagolására (Proposal for new lithosratigraphic units of Hungary). - Ann. Rep. Hung. Geol. Inst., 2004, pp. 195-232 (In Hungarian with English abstract.)

Hámor, G. 1964: A mecseki slir biofáciesvizsgálata (Biofaziesuntersuchungen am Schlier des Mecsekgebirges). - Földt. Közl., 94/3, pp. 349-361 (In Hungarian with German abstract.)

Hámor, G. 1970: A kelet-mecseki miocén (Das Miozän des östlichen Mecsek Gebirges). - Ann. Hung. Geol. Inst., 53/1, 483 p. (In Hungarian with German text.)

Hámor, G. 1972: Nógrád-cserháti terület kutatási eredményei (Investigation results of the Nógrád-Cserhát area). - Ann. Rep. Hung. Geol. Inst., 1970, pp. 19-34 (In Hungarian with English abstract.)

Hámor, G. 1973: Az üledékképződés és szerkezetalakulás összefüggései epirogén területeken (Connections of sedimentation and structural formation in epeirogenic areas). - Földt. Közl., 103, pp. 245-250 (In Hungarian.)

Hámor, G. 1974: A Börzsöny hegység D-i részének ősföldrajzi vázlata (Palaeogeographic outline of the S part of the Börzsöny Mts.). - Ann. Rep. Hung. Geol. Inst., 1972, pp. $23-32$ (In Hungarian with English abstract).

Hámor, G. 1975: Magyarázó a Mecsek hegység földtani térképéhez, 10.000-es sorozat. Bonyhád (Explanatory notes to the geological map of Mecsek Mts., series 10.000, Bonyhád). - Hung. Geol. Inst., 30 p., Budapest (In Hungarian.)

Hámor, G. 1978: Die Orogenphasen des Badenien. Chronostratigraphie und Neostratotypen. VEDA, 109 p., Bratislava.

Hámor, G. 1983: The quantitative methods of palaeogeographical reconstruction. - Hung. Geol. Inst., Spec. Paper, 2, pp. 3-70. 
Hámor, G. 1984: Palaeogeographic reconstruction of Neogene plate movements in the Paratethyan realm. - Acta Geol. Hung., 27/1-2, pp. 5-21.

Hámor, G. 1985: A Nógrád-cserháti kutatási terület földtani viszonyai (Geology of the NógrádCserhát area). - Geol. Hung. Ser. Geol., 22, 307 p.

Hámor, G. (Ed.) 1989: Neogene Palaeogeographic Atlas of Central and Eastern Europe, 1:3,000,000. Maps 1-7. - Hung. Geol. Inst., Budapest.

Hámor, G. 1997: Neogene evolutionary, palaeogeographic and facies model of the Pannonian Basin with lithostratigraphic units. - Geological Atlas of Hungary, 1:500,000, 19, Hung. Geol. Inst., Budapest.

Hámor, G. 2001a: Miocene palaeogeography of the Carpathian Basin. Explanatory notes to the Miocene palaeographic maps of the Carpathian Basin, 1:3.000.000. - Hung. Geol. Inst., 70 p., App. 1-6, Budapest.

Hámor, G. 2001b: Genesis and evolution of the Pannonian Basin. - In: Haas, J. (Ed.): Geology of Hungary. - Eötvös Kiadó, pp. 193-265, Budapest.

Hámor, G. 2002: Significance of the Neo-Vardar Tectonic Zone in the Tertiary structural evolution and paleogeographic changes of the Carpathian Basin. - Acta Geol. Hung., 45/1, pp. 63-77.

Hámor, G. 2005: A Börzsöny-Visegrádi hegység fejlődéstörténete az ősföldrajzi rekonstrukciók tükrében (Evolution of the Börzsöny-Visegrád Mts in the light of the palaeogeographic reconstruction). - Börzsönyvidék, 3, pp. 77-101.

Hámor, G., J. Halmai 1995: Proposal for the definition of the Miocene superstages in the Paratethyan region. - Romanian Journal of Stratigraphy, 76, Suppl. 7, pp. 37-41.

Hámor, G., M. Lantos 2001: Neogene chronostratigraphic correlation of the Carpathian Basin and the Hungarian magnetostratigraphic scale. Explanatory notes to the Miocene palaeogeographic maps of the Carpathian Basin, 1:3.000.000. - Hung. Geol. Inst., App. VII, Budapest.

Hámor, G., Gy. Pogácsás, Á. Jámbor 2001: Paleogeographic/structural evolutionary stages and the related volcanism of the Carpathian-Pannonian Region. - Acta Geol. Hung., 44/2-3, pp. 193-222.

Hámor, T. 1992: A Szirák 2 sz. alapfúrás földtani eredményei (The geological results of the drilling Szirák-2). - Ann. Rep. Hung. Geol. Inst., 1990, pp. 139-168 (In Hungarian with English abstract.)

Jámbor, Á. 1976: Üledékes kéntelep a Zsámbéki-medence szarmata sorozatában (Sedimentary sulfur deposits in the Sarmatian sequence of the Zsámbék Basin; Transdanubia, Hungary). - Ann. Rep. Hung. Geol. Inst., 1974, pp. 301-306 (In Hungarian with English abstract.)

Juhász, Gy. 1991: Sedimentological and lithostratigraphical framework of the Pannonian s.l. sequence in the Hungarian Plain, Eastern Hungary. - Acta Geol. Hung., 34/1-2, pp. 53-72.

Kókay, J. 1987: Central and Eastern Paratethyan interrelations in the light of Late Badenian salinity conditions. - Geol. Hung. Ser. Pal., 48, pp. 7-95.

Nagy, E. 2005: Palynological evidence for Neogene climatic change in Hungary. - Occ. Pap. of the Hung. Geol. Inst., 205, 120 p.

Noszky, J. sen. 1912: A salgótarjáni szénterület földtani viszonyai (Geological structure of coal area of Salgótarján). - Koch-emlékkönyv, pp. 67-90, Budapest (In Hungarian.)

Noszky, J. sen. 1931: A Magyar Középhegység ÉK-i részének oligocén-miocén rétegei, II. A miocén (Oligocene-Miocene layers of the NE part of the Hungarian Range, II. The Miocene). - Ann. Mus. Nat. Hist. Nat., 27, pp. 159-204 (In Hungarian.)

Peters, K. 1861: Die Miozän-Lokalität Hidas bei Fünfkirchen in Ungarn. - Sitzber. k. Akad. Wiss. math., nat. w., 44/2, Wien.

Schafarzik, F. 1892: A Cserhát piroxénandezitjei (Pyroxene andesites of Cserhát Mts.). - Ann. Hung. Geol. Inst., 9, pp. 173-327 (In Hungarian.)

Steininger, F.F, J. Senes, K. Kleemann, F. Rögl (Eds) 1985: Neogene of the Mediterranean Tethys and Paratethys. Stratigraphic Correlation Tables and Sediment Distribution Maps I, II. - Inst. Pal., Univ. Wien, 189 and 536 p., Wien. 
Stevanović, P.M. 1986: Begrenzung und Korrelation der messinischen und pontischen Stufe (eine kritische Rückschau auf Grund der Malakofauna). - Ann. Géol. Pénins. Balkanique, 50, pp. 75-90.

Strausz, L. 1923: Az északkeleti Cserhát torton fáciesei (Tortonian facies of NE Cserhát Mts.). - Math. Term. Tud. Ért., 40, pp. 144-151 (In Hungarian.)

Strausz, L. 1929: A bujáki lajtameszek (Leitha limestones at village Buják). - Földt. Közl., 58/1, pp. 65-69 (In Hungarian.)

Taktakisvili, I.G. 1987: Sistematika i filogenija pliocenovyh kardiid Paratetisa. - Mecniereba, 247 p., Tbilisi (in Russian).

Vadász, E. 1914: Die geologischen Verhältnisse des Zengozuges und der angrenzenden Hügelländer. - Jahresbericht der Kön. Ung. Geol. Reichsanst., 1913, pp. 381-400 (In German.) 